Nevada

Environmental

Restoration

Project

Streamlined Approach for

Environmental Restoration (SAFER)

Plan for Corrective Action Unit 177:

Mud Pits and Cellars

Nevada Test Site, Nevada

Controlled Copy No.:

Revision No.: 0

June 2006

Approved for public release; further dissemination unlimited.

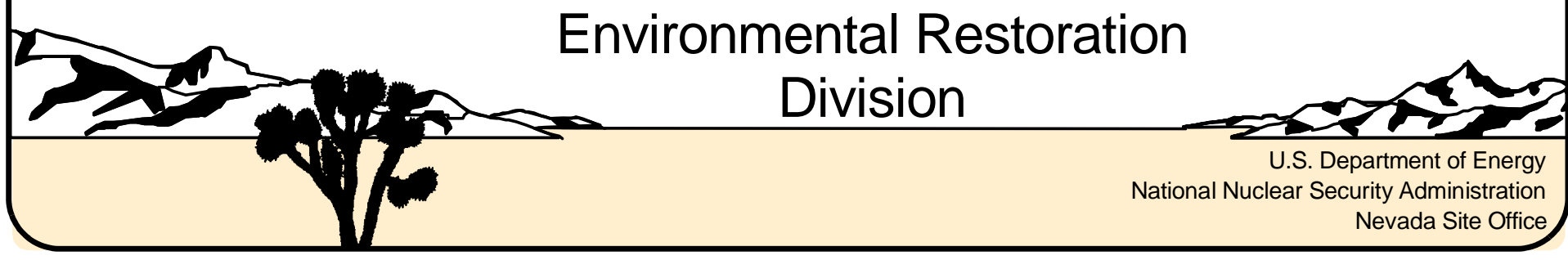


Available for public sale, in paper, from:

\section{U.S. Department of Commerce}

National Technical Information Service

5285 Port Royal Road

Springfield, VA 22161

Phone: 800.553 .6847

Fax: 703.605.6900

Email: orders@ntis.gov

Online ordering: http://www.ntis.gov/ordering.htm

Available electronically at http://www.osti.gov/bridge

Available for a processing fee to U.S. Department of Energy and its contractors, in paper, from:

\section{U.S. Department of Energy}

Office of Scientific and Technical Information

P.O. Box 62

Oak Ridge, TN 37831-0062

Phone: 865.576.8401

Fax: 865.576.5728

Email: reports@adonis.osti.gov

Reference herein to any specific commercial product, process, or service by trade name, trademark, manufacturer, or otherwise, does not necessarily constitute or imply its endorsement, recommendation, or favoring by the United States Government or any agency thereof or its contractors or subcontractors. 


\title{
STREAMLINED APPROACH FOR ENVIRONMENTAL RESTORATION (SAFER) PLAN FOR CORRECTIVE ACTION UNIT 177: MUD PITS AND CELLARS NEVADA TEST SITE, NEVADA
}

\author{
U.S. Department of Energy \\ National Nuclear Security Administration \\ Nevada Site Office \\ Las Vegas, Nevada
}

Controlled Copy No.:

Revision No.: 0

June 2006

Approved for public release; further dissemination unlimited. 
STREAMLINED APPROACH FOR ENVIRONMENTAL RESTORATION (SAFER)

PLAN FOR CORRECTIVE ACTION UNIT 177: MUD PITS AND CELLARS NEVADA TEST SITE, NEVADA

Approved by: APPROVED SIGNATURE Date: 6/06/2006

Approved by: APPROVED SIGNATURE Date: 6/06/2006

Janet Appenzeller-Wing

Federal Project Director

Environmental Restoration Project 


\section{Table of Contents}

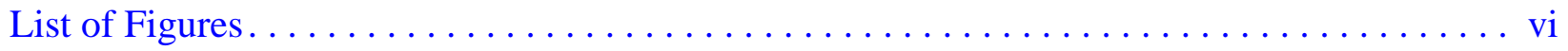

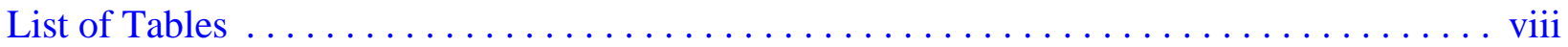

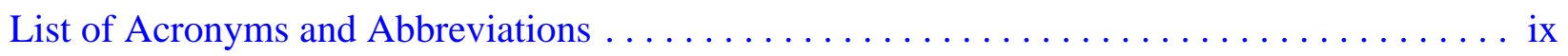

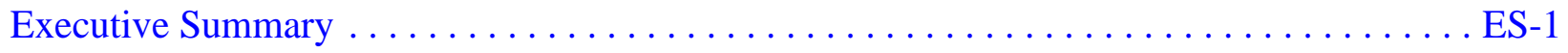

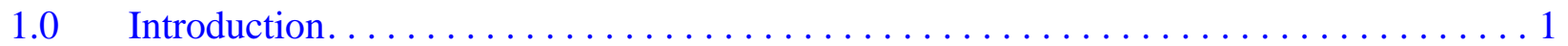

$1.1 \quad$ SAFER Process Description. ............................ 3

1.2 Summary of Corrective Actions and Closures $\ldots \ldots \ldots \ldots \ldots \ldots \ldots \ldots$

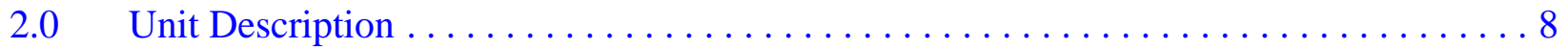

$2.1 \quad$ General Description $\ldots \ldots \ldots \ldots \ldots \ldots \ldots \ldots \ldots \ldots \ldots \ldots \ldots \ldots \ldots$

2.1.1 Mud Pit Process ............................ 8

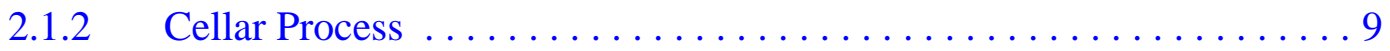

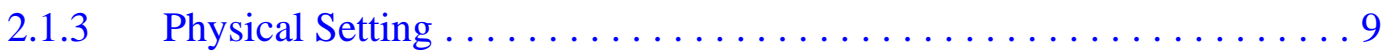

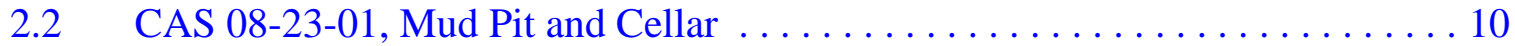

2.2.1 Description and Location......................... 10

2.2.2 History and Process Knowledge $\ldots \ldots \ldots \ldots \ldots \ldots \ldots \ldots \ldots$

2.2.3 Available Characterization Information ................. 10

2.3 CAS 09-09-41, Unknown \#3 Mud Pit/Disposal Area . . . . . . . . . . . . . . 12

2.3.1 Description and Location........................... 12

2.3.2 History and Process Knowledge $\ldots \ldots \ldots \ldots \ldots \ldots \ldots \ldots \ldots \ldots \ldots \ldots$

2.3.3 Available Characterization Information ................. 12

2.4 CAS 09-09-45, U-9bz PS \#1A Mud Pit (1) and Cellar ................ 14

2.4.1 Description and Location............................ 14

2.4.2 History and Process Knowledge ...................... 15

2.4.3 Available Characterization Information .................. 15

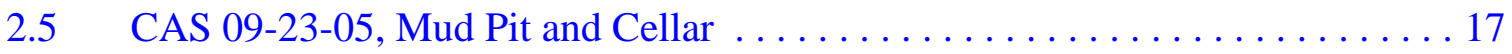

2.5 .1 Description and Location........................... 17

2.5.2 History and Process Knowledge $\ldots \ldots \ldots \ldots \ldots \ldots \ldots \ldots \ldots \ldots$

2.5.3 Available Characterization Information . . . . . . . . . . . . . 17

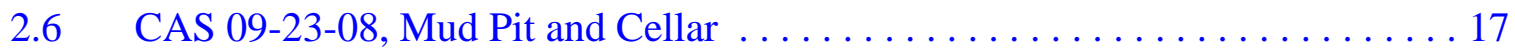

2.6.1 Description and Location.......................... 17

2.6.2 History and Process Knowledge $\ldots \ldots \ldots \ldots \ldots \ldots \ldots \ldots \ldots$

2.6.3 Available Characterization Information ................ 19

2.7 CAS 09-23-09, U-9itsx20 PS\#1A Cellar . . . . . . . . . . . . . . . . . . . 19

2.7.1 Description and Location.......................... 19

2.7.2 History and Process Knowledge $\ldots \ldots \ldots \ldots \ldots \ldots \ldots \ldots \ldots \ldots \ldots \ldots \ldots$

2.7.3 Available Characterization Information ................ 22

2.8 CAS 10-23-02, Mud Pit and Cellar $\ldots \ldots \ldots \ldots \ldots \ldots \ldots \ldots \ldots \ldots \ldots \ldots \ldots \ldots \ldots \ldots$ 


\section{Table of Contents (Continued)}

2.8.1 Description and Location. . . . . . . . . . . . . . . 22

2.8.2 History and Process Knowledge . . . . . . . . . . . . . . . 22

2.8.3 Available Characterization Information . . . . . . . . . . . . . . . 24

2.9 CAS 10-23-03, Mud Pit and Cellar . . . . . . . . . . . . . . . . . 24

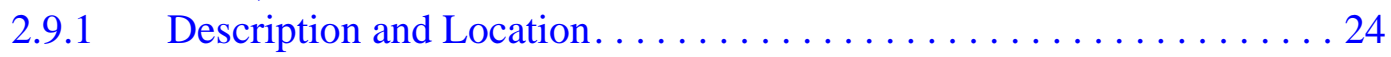

2.9.2 History and Process Knowledge . . . . . . . . . . . . . . . 24

2.9.3 Available Characterization Information . . . . . . . . . . . . . 26

2.10 CAS 19-23-01, Mud Pit and Cellar . . . . . . . . . . . . . . . 26

2.10 .1 Description and Location. . . . . . . . . . . . . . . . 26

2.10 .2 History and Process Knowledge .................... 26

2.10 .3 Available Characterization Information . . . . . . . . . . . . 26

2.11 CAS 19-23-02, Cellar and Waste Storage Area . . . . . . . . . . . . . . 28

2.11 .1 Description and Location. . . . . . . . . . . . . . . . 28

2.11 .2 History and Process Knowledge $\ldots \ldots \ldots \ldots \ldots \ldots \ldots \ldots \ldots \ldots$

2.11 .3 Available Characterization Information . . . . . . . . . . . . . 28

2.12 CAS 19-23-03, Cellar with Casing . . . . . . . . . . . . . . . . 30

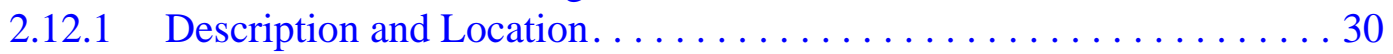

2.12 .2 History and Process Knowledge . . . . . . . . . . . . . 30

2.12 .3 Available Characterization Information . . . . . . . . . . . . . 30

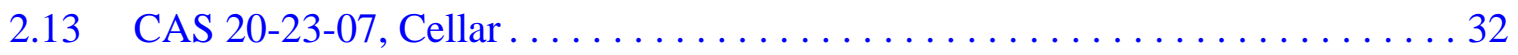

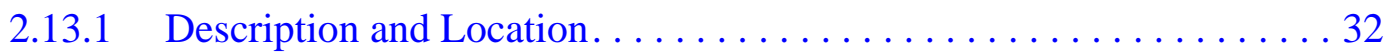

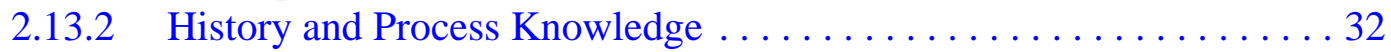

2.13 .3 Available Characterization Information . . . . . . . . . . . . . 32

3.0 Data Quality Objectives . . . . . . . . . . . . . . . . . . . . . 34

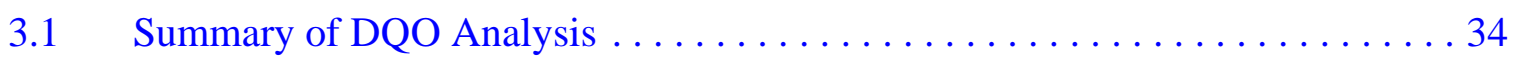

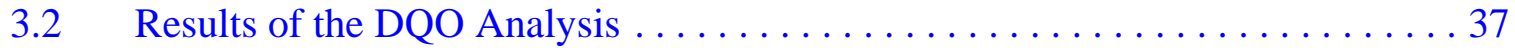

3.2.1 Action Level Determination and Basis . . . . . . . . . . . . . 37

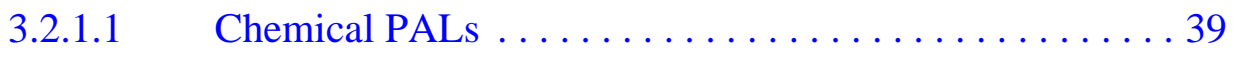

3.2.1.2 Total Petroleum Hydrocarbon PALs . . . . . . . . . . 39

3.2.1.3 Radionuclide PALs . . ................. 39

3.2.2 Hypothesis Test . . . . . . . . . . . . . . . . . . . . . 40

3.2.3 Statistical Model . . . . . . . . . . . . . . . . . . . 40

3.2.4 Design Description/Option . . . . . . . . . . . . . . . . . 40

3.2.4.1 Judgmental Sampling $\ldots \ldots \ldots \ldots \ldots \ldots \ldots \ldots \ldots$

3.2.4.2 Probabilistic Sampling ..................... 41

3.2.5 Conceptual Site Model and Drawing. . . . . . . . . . . . . 41

$4.0 \quad$ Field Activities and Closure Objectives . . . . . . . . . . . . . . . . . 45

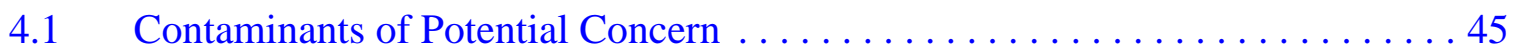

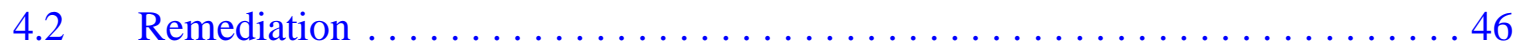




\section{Table of Contents (Continued)}

4.2.1 Field Activities......................... 47

4.2.1.1 Site Preparation Activities ................... 48

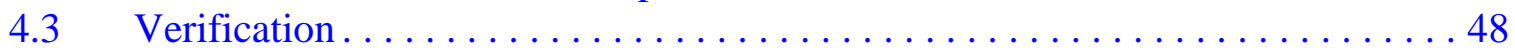

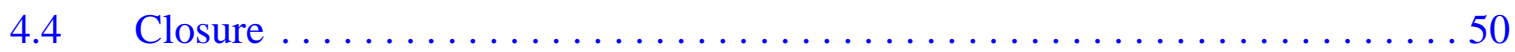

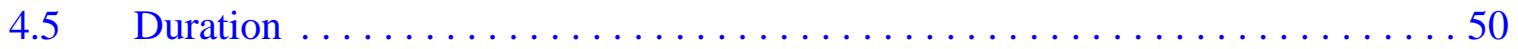

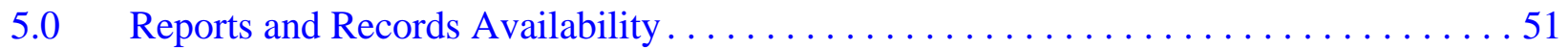

$6.0 \quad$ Investigation/Remediation Waste Management .................... 52

$6.1 \quad$ Waste Minimization ................................... 52

$6.2 \quad$ Potential Waste Streams . . . . . . . . . . . . . . . . . . . . . . . 53

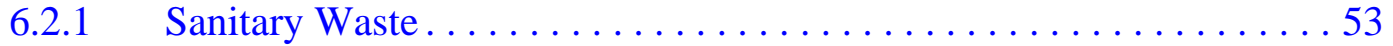

6.2.2 Low-Level Radioactive Waste. ....................... 55

6.2.3 Hazardous Waste . . . . . . . . . . . . . . . . . . . . . . 56

6.2.4 Hydrocarbon Waste ............................ 56

6.2 .5 Mixed Low-Level Waste........................ 56

6.2.6 Polychlorinated Biphenyls. . . . . . . . . . . . . . . . . . . . . 57

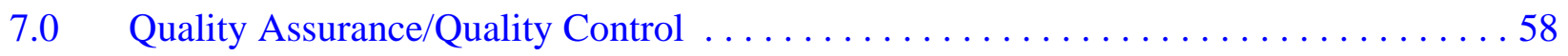

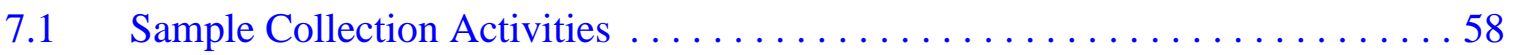

7.2 Applicable Laboratory/Analytical Data Quality Indicators . . . . . . . . . . . 59

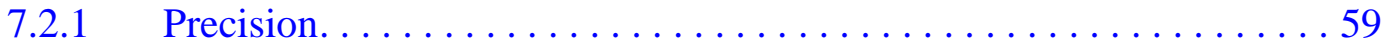

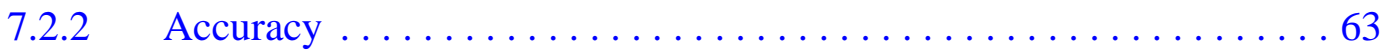

7.2.3 Representativeness............................64 64

$7.2 .4 \quad$ Completeness................................65

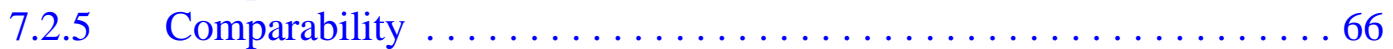

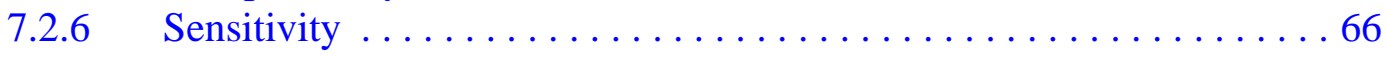

$8.0 \quad$ References...................................... 67

\section{Appendix A - Project Organization}

A.1 Project Organization . . . . . . . . . . . . . . . . . . . . . . . . . .

\section{Appendix B - Data Quality Objective Process}

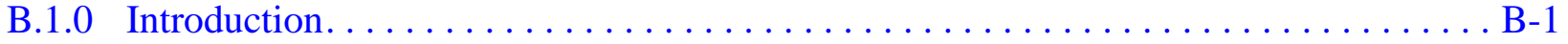

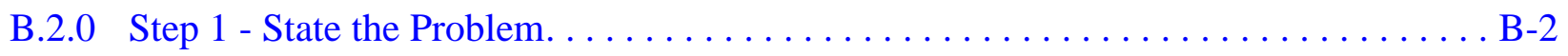

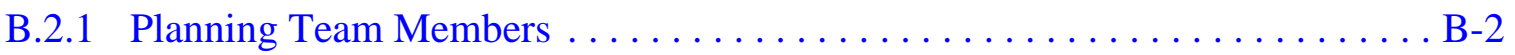

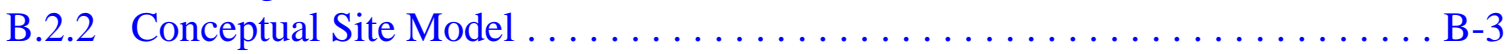

B.2.2.1 Contaminant Release ......................... B-4

B.2.2.1.1 Mud Pits . ........................... B 


\section{Table of Contents (Continued)}

B.2.2.1.2 Cellars ........................ B-9

B.2.2.2 Potential Contaminants . . . . . . . . . . . . . . . . B-10

B.2.2.3 Contaminant Characteristics . . . . . . . . . . . . . . . B-12

B.2.2.4 Site Characteristics . . . . . . . . . . . . . . . . B-12

B.2.2.5 Migration Pathways And Transport Mechanisms . . . . . . . . . . . B-16

B.2.2.6 Exposure Scenarios . . . . . . . . . . . . . . . . . . B-17

B.3.0 Step 2 - Identify the Decisions . . . . . . . . . . . . . . . . . . B-19

B.3.1 Decision Statements . . . . . . . . . . . . . . . . . . . . . B-19

B.3.2 Alternative Actions to the Decisions . . . . . . . . . . . . . . B-19

B.3.2.1 Alternative Actions to Decision I . . . . . . . . . . . . . . . B-20

B.3.2.2 Alternative Actions to Decision II . . . . . . . . . . . . . . . B-20

B.4.0 Step 3 - Identify the Inputs to the Decision $\ldots \ldots \ldots \ldots \ldots \ldots \ldots \ldots \ldots \ldots \ldots$ B-21

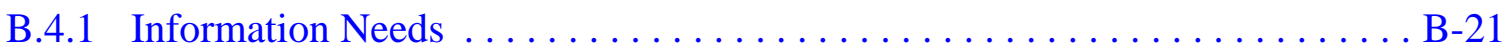

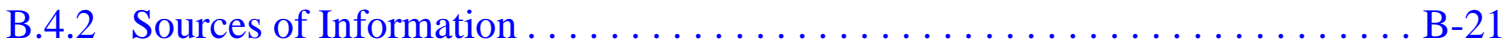

B.4.2.1 Sample Locations. . . . . . . . . . . . . . . . . . . . B-22

B.4.2.1.1 Judgmental Approach for Sample Location

Selection .......................... B-22

B.4.2.1.2 Probabilistic Approach for Sample Location

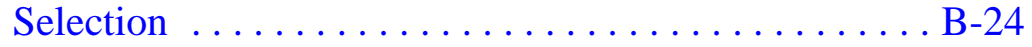

B.4.2.2 Analytical Methods . . . . . . . . . . . . . . . B-26

B.5.0 Step 4 - Define the Boundaries of the Study $\ldots \ldots \ldots \ldots \ldots \ldots \ldots \ldots \ldots \ldots$ B-28

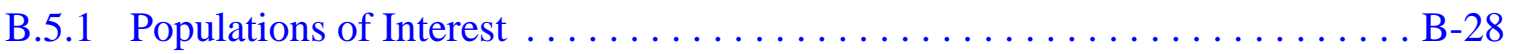

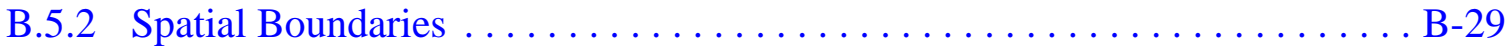

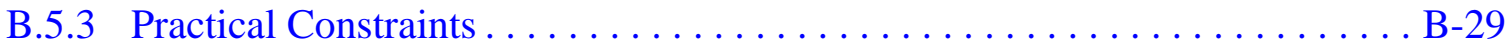

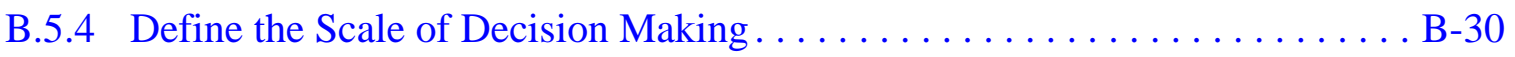

B.6.0 Step 5 - Develop a Decision Rule. . . . . . . . . . . . . . . . . . . . . B-31

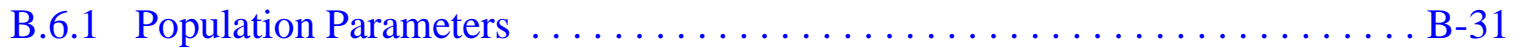

B.6.2 Decision Rules . . . . . . . . . . . . . . . . . . . . . . . . B-31

B.6.3 Action Levels . . . . . . . . . . . . . . . . . . . . . B-32

B.6.4 Measurement and Analysis Sensitivity.................. B-33

B.7.0 Step 6 - Tolerable Limits on Decision Errors . . . . . . . . . . . . . . . . . B-34

B.7.1 False Negative Decision Error . . . . . . . . . . . . . . . B-35

B.7.1.1 False Negative Decision Error for Judgmental Sampling . . . . . . . . B-35

B.7.1.2 False Negative Decision Error for Probabilistic Sampling . . . . . . . . B-37

B.7.2 False Positive Decision Error . . . . . . . . . . . . . . . B-37

B.8.0 Step 7 - Optimize the Design for Obtaining Data. . . . . . . . . . . . . . . B-39 


\section{Table of Contents (Continued)}

B.8.1 Mud Pit Sampling Design. . . . . . . . . . . . . . . . . . B-40

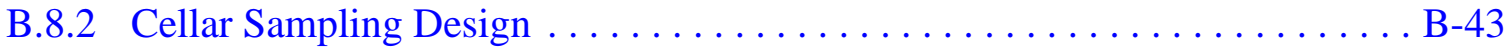

B.9.0 References.................................. B-46

\section{Appendix C - Probabilistic Sampling Plan}

C.1.0 Probabilistic Sampling Plan $\ldots \ldots \ldots \ldots \ldots \ldots \ldots \ldots \ldots \ldots \ldots \ldots \ldots \ldots \ldots \ldots \ldots \ldots \ldots \ldots$

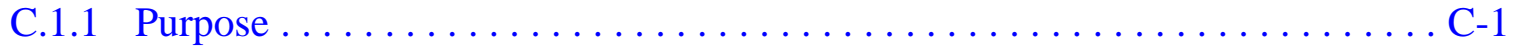

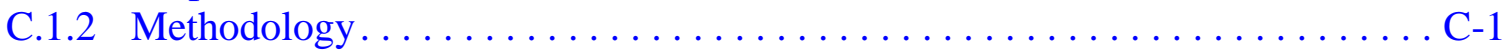

C.1.2.1 Computation of the Upper Confidence Limit . . . . . . . . . . . . . C-2

C.1.2.2 Sample Size .......................... C-2

C.1.2.3 Sample Location Selection $\ldots \ldots \ldots \ldots \ldots \ldots \ldots \ldots \ldots \ldots \ldots \ldots \ldots$

C.2.0 References.................................. C-14

Appendix D - Nevada Division of Environmental Protection Comments 


\section{List of Figures}

Number

Title

Page

1-1 Nevada Test Site Map with CAU 177 CAS Locations . . . . . . . . . . . . . . 2

1-2 CAU 177 Closure Decision Process $\ldots \ldots \ldots \ldots \ldots \ldots \ldots \ldots \ldots \ldots \ldots \ldots \ldots \ldots \ldots \ldots \ldots$

2-1 Corrective Action Site 08-23-01, Mud Pit and Cellar. . . . . . . . . . . . 11

2-2 Corrective Action Site 09-09-41, Unknown \#3 Mud Pit/Disposal Area. . . . . . . 13

2-3 Corrective Action Site 09-09-45, U-9bz PS \#1A Mud Pit (1) and Cellar. . . . . . . 16

2-4 Corrective Action Site 09-23-05, Mud Pit and Cellar. . . . . . . . . . . . . . 18

2-5 Corrective Action Site 09-23-08, Mud Pit and Cellar. . . . . . . . . . . . 20

2-6 Corrective Action Site 09-23-09, U-9itsx20 PS\#1A Cellar . . . . . . . . . . . . . 21

2-7 Corrective Action Site 10-23-02, Mud Pit and Cellar. . . . . . . . . . . . . 23

2-8 Corrective Action Site 10-23-03, Mud Pit and Cellar. . . . . . . . . . . . . . . 25

2-9 Corrective Action Site 19-23-01, Mud Pit and Cellar. . . . . . . . . . . . 27

2-10 Corrective Action Site 19-23-02, Cellar and Waste Storage Area . . . . . . . . . . 29

2-11 Corrective Action Site 19-23-03, Cellar with Casing . . . . . . . . . . . . . 31

2-12 Corrective Action Site $20-23-07$, Cellar . . . . . . . . . . . . . . . 33

3-1 Risk-Based Corrective Action Decision Process $\ldots \ldots \ldots \ldots \ldots \ldots$. . . . . . 38

3-2 Conceptual Site Model Flow Chart for CAU $177 \ldots \ldots \ldots \ldots \ldots \ldots \ldots$

3-3 Conceptual Site Model Diagram for CAU $177 \ldots \ldots \ldots \ldots \ldots \ldots \ldots \ldots$

B.2-1 Conceptual Site Model for CAU $177 \ldots \ldots \ldots \ldots \ldots \ldots \ldots \ldots \ldots \ldots$

B.8-1 Proposed Sample Locations at Mud Pits. . . . . . . . . . . . . . . . . B-42

B.8-2 Proposed Sample Locations at Cellars . . . . . . . . . . . . . . . B-44

C.1-1 Corrective Action Site 08-23-01, Sample Locations and Coordinates . . . . . . . C-4

C.1-2 Corrective Action Site 09-09-41, Sample Locations and Coordinates . . . . . . . C-5

C.1-3 Corrective Action Site 09-09-45, Sample Locations and Coordinates . . . . . . . C-6

C.1-4 Corrective Action Site 09-23-05, Sample Locations and Coordinates . . . . . . . C-7

C.1-5 Corrective Action Site 09-23-08, Sample Locations and Coordinates . . . . . . . C-8 


\section{List of Figures (Continued)}

Number

Title

Page

C.1-6 Corrective Action Site 10-23-02, Sample Locations and Coordinates. . . . . . . C-9

C.1-7 Corrective Action Site 10-23-03, Sample Locations and Coordinates. . . . . . . C-10

C.1-8 Corrective Action Site 19-23-01, Sample Locations and Coordinates, Layout A . . . . . . . . .

C.1-9 Corrective Action Site 19-23-01, Sample Locations and Coordinates, Layout B . . . . . . . . . . .

C.1-10 Corrective Action Site 19-23-01, Sample Locations and

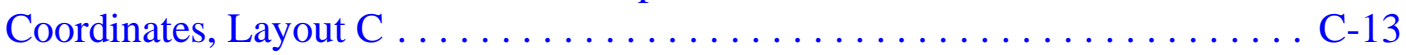




\section{List of Tables}

Number

Title

Page

ES.1-1 Summary of Conceptual Site Model Assumptions and Expected Closures .... ES-3

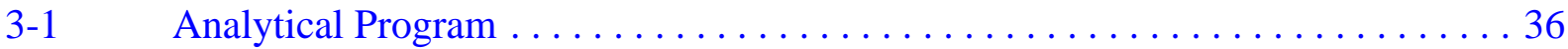

4-1 Targeted Analytes for All CAU 177 CASs . . . . . . . . . . . . 46

4-2 CAU 177 SAFER Project Duration. ................... 50

6-1 Waste Management Regulations and Requirements . . . . . . . . . . . . 54

7-1 Data Quality Indicator Performance Metrics. . . . . . . . . . . 60

7-2 Analytical Requirements for Radionuclides for CAU $177 \ldots \ldots \ldots \ldots$. . . . 61

7-3 Analytical Requirements for Chemical COPCs for CAU $177 \ldots \ldots \ldots$. . . . 62

B.2-1 Data Quality Objective Meeting Participants for CAU 177

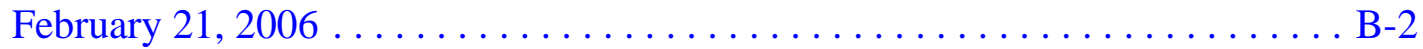

B.2-2 Conceptual Site Model Description of Elements for All

CASs in CAU $177 \ldots \ldots \ldots \ldots \ldots \ldots \ldots \ldots \ldots \ldots \ldots \ldots \ldots \ldots \ldots \ldots \ldots \ldots \ldots \ldots$

B.2-3 Analytical Program . . . . . . . . . . . . . . . . . . . .

B.2-4 Targeted Analytes for CAU $177 \ldots \ldots \ldots \ldots \ldots \ldots \ldots \ldots \ldots \ldots \ldots \ldots \ldots \ldots$

B.2-5 Physical Setting of CAU 177 Corrective Action Sites . . . . . . . . . . . B-14

B.2-6 Future Land-Use and Exposure Scenarios. . . . . . . . . . . . . . . B-18

B.4-1 Parameter Values Established by DQO Participants . . . . . . . . . . . . B-25

B.4-2 Analytes Reported by Analytical Methods . . . . . . . . . . . . . . . . B-27

B.5-1 Spatial Boundaries of CAU 177 Mud Pits and Cellars . . . . . . . . . . . B-29

B.8-1 Summary of Sampling Approach and Data Evaluation, CAU $177 \ldots$. . . . . . B-39 


\section{List of Acronyms and Abbreviations}

\begin{tabular}{|c|c|}
\hline ASTM & American Society for Testing and Materials \\
\hline bgs & Below ground surface \\
\hline $\mathrm{BN}$ & Bechtel Nevada \\
\hline BOP & Blowout preventer \\
\hline CAS & Corrective Action Site \\
\hline CAU & Corrective Action Unit \\
\hline CFR & Code of Federal Regulations \\
\hline COC & Contaminant of concern \\
\hline COPC & Contaminant of potential concern \\
\hline Cs & Cesium \\
\hline CSM & Conceptual site model \\
\hline DOE & U.S. Department of Energy \\
\hline DOT & U.S. Department of Transportation \\
\hline dpm & Disintegrations per minute \\
\hline DQI & Data quality indicator \\
\hline DQO & Data quality objective \\
\hline DRI & Desert Research Institute \\
\hline DRO & Diesel-range organics \\
\hline EPA & U.S. Environmental Protection Agency \\
\hline EQL & Estimated quantitation limit \\
\hline $\mathrm{Eu}$ & Europium \\
\hline FAL & Final action level \\
\hline FFACO & Federal Facility Agreement and Consent Order \\
\hline FSR & Field-screening result \\
\hline $\mathrm{ft}$ & Foot \\
\hline $\mathrm{ft}^{2}$ & Square foot \\
\hline
\end{tabular}




\section{List of Acronyms and Abbreviations (Continued)}

GPS Global Positioning System

HWAA Hazardous waste accumulation area

IDW Investigation-derived waste

in. Inch

LANL Los Alamos National Laboratory

LCS Laboratory control sample

LLNL Lawrence Livermore National Laboratory

MDC Minimum detectable concentration

$\mathrm{mg} / \mathrm{kg} \quad$ Milligrams per kilogram

mi Mile

$\mathrm{mR} / \mathrm{hr} \quad$ Milliroentgens per hour

MRL Minimum reporting level

MS Matrix spike

N/A Not applicable

NAC Nevada Administrative Code

ND Normalized difference

NDEP Nevada Division of Environmental Protection

NNSA/NSO U.S. Department of Energy, National Nuclear Security Administration Nevada Site Office

NRS Nevada Revised Statutes

NTS Nevada Test Site

NTSWAC Nevada Test Site Waste Acceptance Criteria

PAL Preliminary action level

$\mathrm{Pb} \quad$ Lead

PCB Polychlorinated biphenyl

$\mathrm{pCi} / \mathrm{g} \quad$ Picocuries per gram

POC Performance Objective for the Certification of Nonradioactive Hazardous Waste 


\section{List of Acronyms and Abbreviations (Continued)}

\begin{tabular}{|c|c|}
\hline PPE & Personal protective equipment \\
\hline ppm & Parts per million \\
\hline PRG & Preliminary remediation goal \\
\hline $\mathrm{Pu}$ & Plutonium \\
\hline QA & Quality assurance \\
\hline QAPP & Quality Assurance Project Plan \\
\hline QC & Quality control \\
\hline RadCon & Radiation Control \\
\hline RBCA & Risk-based corrective action \\
\hline RBCSR & Risk-Based Closure Strategy Report \\
\hline RBSL & Risk-based screening level \\
\hline RCRA & Resource Conservation and Recovery Act \\
\hline REECo & Reynolds Electrical \& Engineering Co., Inc. \\
\hline $\mathrm{RL}$ & Reporting level \\
\hline RMA & Radioactive material area \\
\hline ROTC & Record of Technical Change \\
\hline RPD & Relative percent difference \\
\hline SAA & Satellite accumulation area \\
\hline SAFER & Streamlined Approach for Environmental Restoration \\
\hline SNJV & Stoller-Navarro Joint Venture \\
\hline $\mathrm{Sr}$ & Strontium \\
\hline SS & Site Supervisor \\
\hline SSTL & Site-specific target level \\
\hline SVOC & Semivolatile organic compound \\
\hline ТPH & Total petroleum hydrocarbons \\
\hline TSCA & Toxic Substances Control Act \\
\hline
\end{tabular}




\section{List of Acronyms and Abbreviations (Continued)}

$\mathrm{U}$

Uranium

UCL

Upper confidence limit

VOC

Volatile organic compound

VSP

Visual Sample Plan

$\% \mathrm{R}$

Percent recovery 


\section{Executive Summary}

This Streamlined Approach for Environmental Restoration (SAFER) Plan addresses closure for Corrective Action Unit (CAU) 177, Mud Pits and Cellars, identified in the Federal Facility Agreement and Consent Order. Corrective Action Unit 177 consists of the 12 following Corrective Action Sites (CASs) located in Areas 8, 9, 19, and 20 of the Nevada Test Site:

- 08-23-01, Mud Pit and Cellar

- 09-09-41, Unknown \#3 Mud Pit/Disposal Area

- 09-09-45, U-9bz PS \#1A Mud Pit (1) and Cellar

- 09-23-05, Mud Pit and Cellar

- 09-23-08, Mud Pit and Cellar

- 09-23-09, U-9itsx20 PS\#1A Cellar

- 10-23-02, Mud Pit and Cellar

- 10-23-03, Mud Pit and Cellar

- 19-23-01, Mud Pit and Cellar

- 19-23-02, Cellar and Waste Storage Area

- 19-23-03, Cellar with Casing

- 20-23-07, Cellar

This plan provides the methodology for field activities needed to gather the necessary information for closing each CAS. There is sufficient information and process knowledge from historical documentation and investigations of similar sites regarding the expected nature and extent of potential contaminants to recommend closure of CAU 177 using the SAFER process.

The data quality objective process developed for this CAU identified the following expected closure options: (1) investigation and confirmation that no contamination exists above the preliminary action levels (PALs), leading to a no further action declaration, or (2) characterization of the nature and extent of contamination, leading to closure in place with use restrictions. The expected closure options were selected based on available information including contaminants of potential concern, future land use, and assumed risks. A decision flow process was developed to outline the collection of data necessary to achieve closure. There are two decisions that need to be answered for closure. Decision I is to determine whether contaminants of potential concern are present in concentrations exceeding the PALs. If contaminants of potential concern are found to be present above PALs, Decision II will be to determine the extent of contamination and generate the information necessary to close the site in place and implement the appropriate administrative controls (i.e., use restrictions). 
The following text summarizes the types of activities that will support the closure of CAU 177:

- Perform site preparation activities (e.g., boundary setup, utility clearances, vegetation removal, movement/removal of fencing and debris).

- Remove non-hazardous debris at various CASs, as required.

- Collect environmental samples of residual drilling mud and soil using probabilistic (mud pits) and judgmental (cellars) sampling to confirm or disprove the presence of contaminants of concern (COCs) (i.e., nature of contamination) if these data do not already exist. Collect environmental samples from designated target populations (e.g., clean soil adjacent to contaminated soil if COCs exist) and submit for laboratory analyses to define the extent of COC contamination.

- Establish no further action as the corrective action if no contaminants are detected above final action levels.

- If COCs are present at a CAS, establish the corrective action and implement appropriate use restrictions.

- Confirm the preferred closure option is sufficient to protect human health and the environment.

- Document all closure activities for CAU 177 in a Closure Report.

Historical information and process knowledge identified sources of potential contamination for the mud pits and cellars. See Table ES.1-1 for a summary of the conceptual site model assumptions and expected closures.

Under the Federal Facility Agreement and Consent Order, the SAFER Plan will be submitted to the Nevada Division of Environmental Protection for approval. Field work will be conducted following approval of the plan. On completion of the field activities, a Closure Report will be prepared and submitted to the Nevada Division of Environmental Protection for review and approval. 
Table ES.1-1

Summary of Conceptual Site Model Assumptions and Expected Closures

\begin{tabular}{|c|c|c|c|}
\hline $\begin{array}{l}\text { Corrective } \\
\text { Action Sites }\end{array}$ & Potential Release of COCs & $\begin{array}{c}\text { Conceptual Site Model } \\
\text { Assumptions }\end{array}$ & $\begin{array}{l}\text { Expected } \\
\text { Closure }\end{array}$ \\
\hline $\begin{array}{l}\text { Mud Pits: } \\
\text { 08-23-01, 09-09-41, } \\
\text { 09-09-45, 09-23-05, } \\
\text { 09-23-08, 10-23-02, } \\
\text { 10-23-03, 19-23-01 }\end{array}$ & $\begin{array}{l}\text { Primary source for radiological } \\
\text { contamination is a release of drilling } \\
\text { mud associated with post-test drilling } \\
\text { activities subsequent to underground } \\
\text { nuclear testing. } \\
\text { The locations of a release are } \\
\text { expected to be limited to the } \\
\text { boundaries of the mud pit } \\
\text { walls/berms, or at drilling mud spills } \\
\text { adjacent to the mud pit. }\end{array}$ & $\begin{array}{l}\text { Contamination at a mud pit is } \\
\text { expected to be bound within the } \\
\text { residual mud and would not be } \\
\text { expected to migrate vertically } \\
\text { downward into the underlying } \\
\text { soil. } \\
\text { Lateral extent of contamination is } \\
\text { expected to be limited to the } \\
\text { walls/berms of the mud pit. } \\
\text { The only COCs present are } \\
\text { radionuclides. Results from } \\
\text { previous investigations have } \\
\text { indicated that no other COCs are } \\
\text { anticipated. }\end{array}$ & $\begin{array}{l}\text { No further action } \\
\text { with a contingency } \\
\text { for closure in place } \\
\text { with use restriction }\end{array}$ \\
\hline $\begin{array}{l}\text { Cellars: } \\
\text { 08-23-01, 09-09-45, } \\
\text { 09-23-05, 09-23-08, } \\
\text { 09-23-09, 10-23-02, } \\
\text { 10-23-03, 19-23-01, } \\
\text { 19-23-02, 19-23-03, } \\
\text { 20-23-07 }\end{array}$ & $\begin{array}{l}\text { Primary source for chemical } \\
\text { contamination is a direct release of } \\
\text { drill rig fluids (e.g., hydraulic fluid, } \\
\text { oils, greases, diesel fuel), } \\
\text { decontamination rinsate, or } \\
\text { discarding of potentially hazardous } \\
\text { drilling materials. } \\
\text { The primary source for radiological } \\
\text { contamination is an accidental } \\
\text { release of contaminated drilling mud } \\
\text { via spills, or leaks from defective } \\
\text { drilling hoses or tubing } \\
\text { The locations of a release are } \\
\text { expected to be limited to the surface } \\
\text { and shallow subsurface soils at the } \\
\text { base of the cellar contained within } \\
\text { the boundaries of the corrugated } \\
\text { metal casing. }\end{array}$ & $\begin{array}{l}\text { Vertical movement of } \\
\text { contaminants in the affected } \\
\text { media of a cellar, if any, is } \\
\text { expected to be limited to several } \\
\text { inches below the base of a cellar. } \\
\text { Lateral extent of contamination in } \\
\text { cellars is expected to be limited } \\
\text { by the metal casing that } \\
\text { surrounds the cellar cavity. } \\
\text { The cocs present may include } \\
\text { both chemical and radiological } \\
\text { constituents. }\end{array}$ & $\begin{array}{l}\text { No further action } \\
\text { with a contingency } \\
\text { for closure in place } \\
\text { with use restriction }\end{array}$ \\
\hline
\end{tabular}

$\mathrm{COC}=$ Contaminant of concern 


\subsection{Introduction}

This Streamlined Approach for Environmental Restoration (SAFER) Plan addresses the actions necessary for the closure of Corrective Action Unit (CAU) 177: Mud Pits and Cellars, Nevada Test Site (NTS), Nevada. It has been developed in accordance with the Federal Facility Agreement and Consent Order (FFACO) (1996) that was agreed to by the State of Nevada, the U.S. Department of Energy (DOE), and the U.S. Department of Defense.

A SAFER may be performed when the following criteria are met:

- Conceptual corrective actions are clearly identified (although some degree of investigation may be necessary to select a specific corrective action before completion of the SAFER)

- Uncertainty of the nature, extent, and corrective action must be limited to an acceptable level of risk

- The SAFER Plan includes decision points and criteria for making DQO decisions

The purpose of the investigation will be to document and verify the adequacy of existing information; affirm the decision for clean closure, closure in place, or no further action (NFA); and provide sufficient data to implement the corrective action. The actual corrective action selected will be based on characterization activities implemented under this SAFER Plan. This SAFER Plan identifies decision points developed in cooperation with the Nevada Division of Environmental Protection (NDEP), where the DOE, National Nuclear Security Administration Nevada Site Office (NNSA/NSO) will reach consensus with NDEP before beginning the next phase of work.

Corrective Action Unit 177 is comprised of 12 corrective action sites (CASs) located in Areas 8, 9, 19, and 20 of the NTS, which is approximately 65 miles (mi) northwest of Las Vegas, Nevada (Figure 1-1). Two CAS numbers (10-23-02 and 10-23-03) indicate a location of Area 10, but the CASs are actually located in Area 8. The 12 CASs of CAU 177 are shown on Figure 1-1 and listed below:

- 08-23-01, Mud Pit and Cellar

- 09-09-41, Unknown \#3 Mud Pit/Disposal Area

- 09-09-45, U-9bz PS \#1A Mud Pit (1) and Cellar

- 09-23-05, Mud Pit and Cellar 


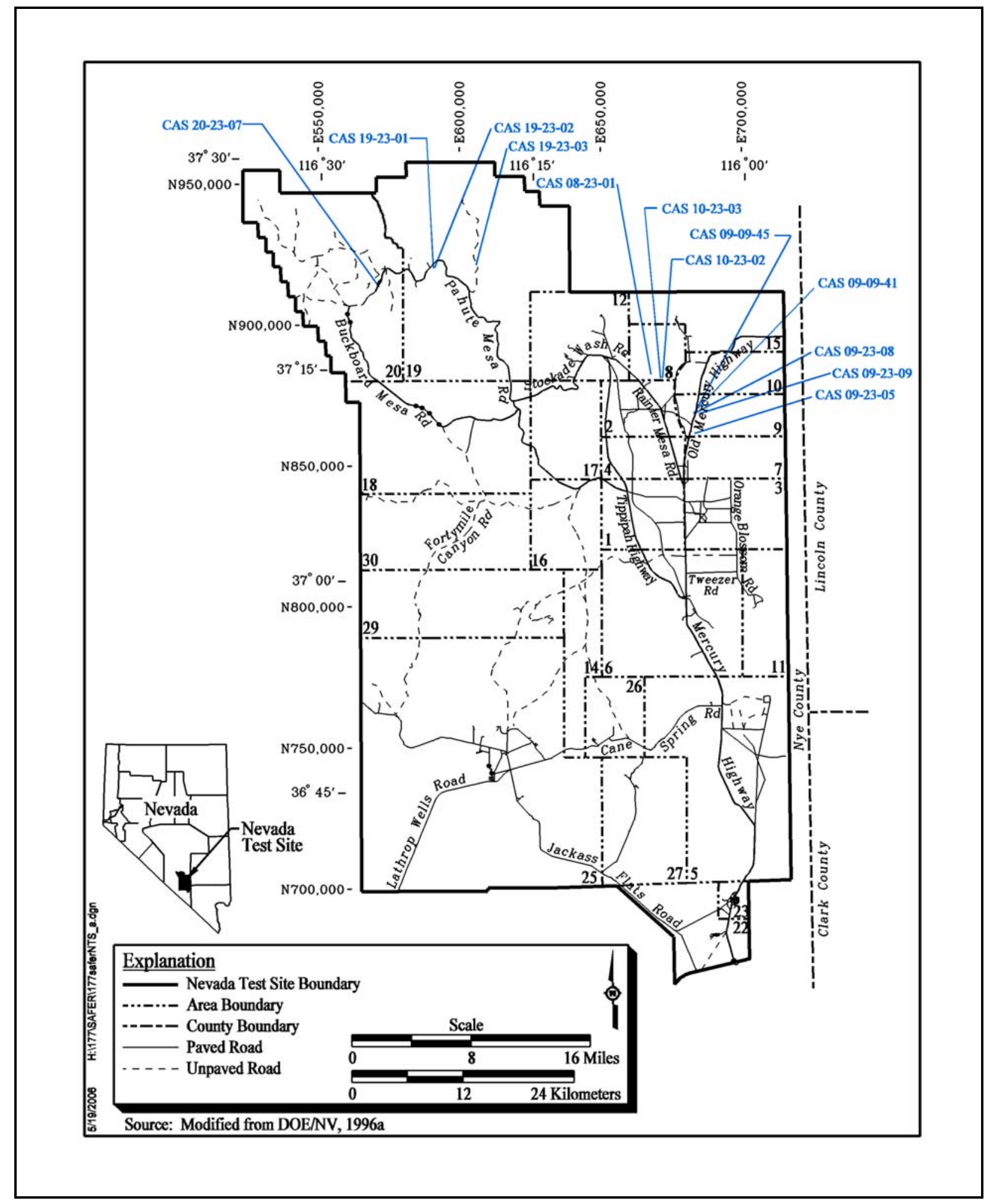

Figure 1-1

Nevada Test Site Map with CAU 177 CAS Locations 
- 09-23-08, Mud Pit and Cellar

- 09-23-09, U-9itsx20 PS\#1A Cellar

- 10-23-02, Mud Pit and Cellar

- 10-23-03, Mud Pit and Cellar

- 19-23-01, Mud Pit and Cellar

- 19-23-02, Cellar and Waste Storage Area

- 19-23-03, Cellar with Casing

- 20-23-07, Cellar

There is sufficient information and process knowledge from historical documentation and investigations of similar sites (i.e., the expected nature and extent of contaminants of potential concern [COPCs]) to recommend closure of CAU 177 using the SAFER process (FFACO, 1996). The Mud Pit Risk-Based Closure Strategy Report (RBCSR) (NNSA/NSO, 2004a) was approved by NDEP and documented the expected nature and extent of COPCs at mud pits for CAUs 530-535. The RBCSR presented sufficient information relating to process knowledge of mud pit operations and investigation results from similar mud pits to implement the SAFER process and recommend NFA as the preferred closure alternative for CAUs 530-535. The SAFER process was also successfully applied to CAUs 355, 356, and 358, which includes both mud pits and associated cellars.

\subsection{SAFER Process Description}

The CAUs that may be closed using the SAFER process have conceptual corrective actions that are clearly identified. Consequently, corrective action alternatives can be chosen before completing a corrective action investigation, given anticipated investigation results.

The SAFER process combines elements of the data quality objective (DQO) process and the observational approach to plan and conduct closure activities. The DQOs are used to identify the problem and define the type and quality of data needed to complete closure of each CAS. The purpose of the investigation phase is to verify the adequacy of existing information used to determine the chosen corrective action and to confirm that closure objectives were met.

Use of the SAFER process allows for technical decisions to be made based on incomplete but sufficient information, and the experience of the decision-maker. Based on a detailed review of historical documentation, there is sufficient process knowledge to close CAU 177 using the SAFER process. Any uncertainties are addressed by assumptions that are verified by sampling and analysis, 
data evaluation, and on-site observations, as necessary. Closure activities may proceed simultaneously with site characterization as sufficient data are gathered to confirm or disprove the assumptions made during selection of the corrective action. If, at any time during the closure process, new information is discovered that indicates that closure activities should be revised, closure activities will be re-evaluated as appropriate.

\subsection{Summary of Corrective Actions and Closures}

The decision process for closure of CAU 177 is summarized in Figure 1-2. This process starts with the initial investigation in which the appropriate target population(s) within a mud pit or cellar are sampled. The population of interest for a cellar is any location within the cellar that is contaminated with any contaminant above a final action level (FAL) (judgmental sampling), and for a mud pit it is locations representative of site contamination (probabilistic sampling). If contaminants are detected at concentrations that are above the FALs, the extent of contamination will be delineated by additional sampling. However, contingencies are built into the process in the event new information is identified which indicates that the selected, closure option should be revised. The process ends with closure of the site based on laboratory analytical results of the environmental samples and the preparation of a Closure Report. Corrective action alternatives of NFA and closure in place will be evaluated for each CAS.

Decision points that require a consensus be reached between the NNSA/NSO and the Nevada Division of Environmental Protection (NDEP) before continuing are indicated in Figure 1-2.

In addition to the previously discussed hold/decision points, work may be temporarily suspended until the issue can be satisfactorily resolved if any of the following unexpected conditions occur:

- Conditions outside the scope of work are encountered

- Radiological screening yields results that require an upgrade in controls to continue survey work in specific areas

- Elevated levels of additional contaminants of concern (COCs) are found that were not originally identified as being present at the sites

- Unexpected conditions including waste and/or contamination are encountered 
Conduct appropriate probabilitstic

or judgmental sample collection

and analyze for COPCs in target population

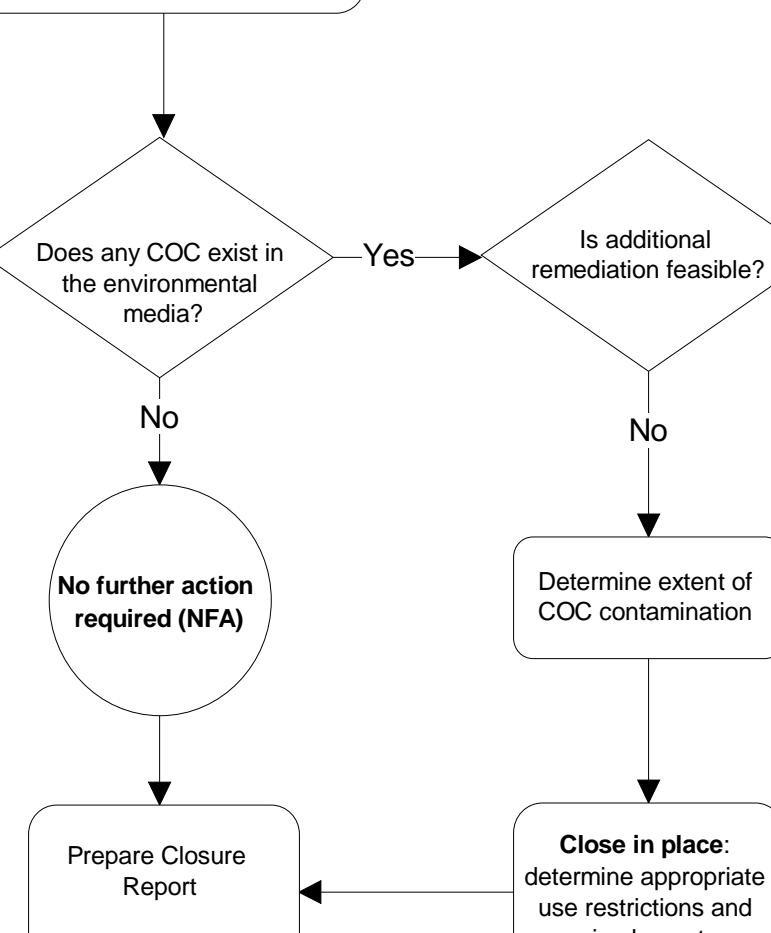

restrictions and

implement

Figure 1-2

CAU 177 Closure Decision Process 
- Out-of-scope work activities are required due to the detection of other COCs that would require re-evaluating a disposal pathway, such as with hazardous or low-level waste

- Unsafe conditions or work practices

The CASs in CAU 177 are anticipated to be closed with the designation NFA as it is believed that application of the risk-based corrective action (RBCA) approach will result in there being no required activity at these CASs. There is also a contingency for individual mud pits and cellars to be closed in place with implementation of use restrictions if a COC is present and there is sufficient information to establish the boundaries of contamination.

Assumptions related to the mud pit process and cellar process that serve as the basis for this investigation are:

- Mud pits in CAU 177 are considered to have resulted from essentially the same process. This is supported by the similarities in drilling mud formulations, drilling practices, and contamination profiles for mud pits within the previously investigated CAUs 530-535 as well as mud pits located on the NTS and at off-site locations (NNSA/NSO, 2004a).

- Drilling fluid in the mud pits was homogenized during drilling operations. In circulating the drilling fluid through the borehole and mud pits, the drilling fluid was continuously mixed and homogenized throughout the pit. This suggests that the surface and shallow subsurface soils of the mud pits are similar, and surface samples are representative of the mud throughout the depth of the mud pit.

- Radionuclides are the only COPCs for mud pits. Circulation of drilling fluids was stopped before reaching the depth potentially affected by the nuclear test during the post-test drilling in order to reduce the likelihood of bringing radioactive material to the surface and into the mud pits. However, it cannot be confirmed that this process was effective or that the circulated drilling fluids discharged into the mud pit did not come into contact with radioactive rock. The mud pits of CAU 177 will therefore be characterized by analyzing residual mud for radionuclides. Identifying radionuclides as the only COPCs for mud pits is supported by results of previous mud pit investigations, which have eliminated chemical constituents including total petroleum hydrocarbons (TPH)-diesel-range organics (DRO) as COPCs.

- Due to the physical properties of the affected media (drilling mud) in mud pits, contamination is expected to be bound within the matrix of the residual mud with no significant lateral or vertical migration. The drilling mud will have low permeability, porosity, and hydraulic conductivity due to the presence of bentonite. These physical properties combined with the high evapotranspiration rates in the desert climate of the NTS suggest no significant vertical migration is expected. This conclusion is supported by 
previous modeling efforts that report the immobility of TPH-DRO in drilling mud and the limited downward migration into underlying soil (DOE/NV, 1998; NNSA/NSO, 2004a). Lateral migration is expected to be minimal given the physical properties of the mud and the bermed construction of the mud pits, which limits potential stormwater run-on and runoff; however, compromises in the integrity of the berm may have resulted in releases that will be included in the sampling effort. Given the lack of contaminant migration and groundwater levels of 500 to 2,800 feet (ft) below ground surface (bgs) at the NTS (USGS and DOE, 2005), no impact to groundwater from contaminants associated with the NTS mud pits is expected.

- Cellars in CAU 177 are considered to have resulted from essentially the same process. This is supported by process knowledge regarding the use and typical construction of a cellar, as well as documented similarities in post-test drilling practices including reports from previously investigated cellars (CAUs 355 and 358) (NNSA/NSO, 2003a and b).

- Chemical constituents and radionuclides are COPCs for cellars. Because sufficient information is not available to eliminate both chemical and radiological contamination as COPCs, the impacted media will be investigated. The primary source of potential chemical contaminants is expected to be from spills/leaks of drill rig fluids, or decontamination of drilling equipment over the cellar cavity. A release of drilling mud to the cellar floor is not expected because drilling fluids were circulated through a closed system. However, the potential exists for radiologically contaminated drilling mud to have spilled or leaked into the cellar cavity as a result of careless activities or a malfunction in the circulation system.

- Due to the typical construction of a cellar, no significant lateral or vertical migration of contaminants is expected. Any contaminants within the impacted media at the base of a cellar would be laterally bound by the corrugated metal casing that lines the cellar cavity. The potentially impacted media within a cellar is expected to be 10 to $12 \mathrm{ft}$ bgs and is buried beneath fill material in all but two CASs (19-23-03 and 20-23-07). Vertical migration of contaminants from infiltration of precipitation is expected to be insignificant. Some cellars have concrete bottoms (NNSA/NSO, 2003a and b), which would further prevent the downward migration of contaminants into the underlying soil.

- It will be assumed that all backfilled cellars contain drill stemming left in place. Observations from open and backfilled cellars indicate that drill stemming from post-test borings were commonly left in place, and were cut off approximately $1 \mathrm{ft}$ above the cellar floor or extend several feet out of the cellar, above the ground surface. Sampling logistics such as access to the cellar floor and sample locations may be affected due to the presence and orientation of drill stemming. Therefore, it will be assumed that all backfilled cellars contain drill stemming for the finalization of the sampling design. 


\subsection{Unit Description}

The mud pits and cellars in CAU 177 were constructed for use during the drilling activities conducted at the NTS in support of the underground nuclear weapons testing program. The mud pits and cellars of the eleven CASs were constructed as part of Los Alamos National Laboratory (LANL) or Lawrence Livermore National Laboratory (LLNL) post-test drilling activities, both of which involved drilling small-diameter holes used to access and collect samples from the area affected by an underground test. The mud pit of the twelfth CAS (09-09-41) is a disposal type pit that was constructed to contain used or excess drilling fluids and is not associated with a borehole.

The environmental media affected by a release will be defined for each feature because the sources of contamination, release points, and affected media are dependent on the separate mud pit and cellar process. For a mud pit, the CAS is the direct release of drilling mud potentially impacted by radiological contamination. For a cellar, the CAS is soil within the base of the cellar potentially impacted by radiological or chemical contaminants from a release of drill rig fluids, decontamination rinsate, or drilling mud.

\subsection{General Description}

This section provides a description of information related to mud pit and cellar processes that are common to all CASs.

\subsubsection{Mud Pit Process}

Post-test drilling operations involved the routine construction of earthen mud pits that were created for the separation of drill cuttings and the circulation of drilling fluids (REECo, 1994; Witt, 2000). Although LANL utilized drilling mud and LLNL used an air-foam mixture (Davis Mix), the drilling processes were essentially the same for both drilling fluids (NNSA/NSO, 2004a). Drilling fluids containing suspended drill cuttings would be deposited into the pit where the cuttings would settle out and the drilling fluid would be circulated back to the borehole. This was a closed system process, so drilling fluids should not have been released into the cellar cavity. However, washing and decontaminating equipment over the cellar was common practice, and, therefore, drilling fluid constituents may have been released to the cellar. Circulation of drilling fluids would cease when 
drilling approached the depth potentially affected by the nuclear test. This reduced the likelihood of contaminating the mud pits with radioactive material or releasing radioactive material to the surface (Wilkes, 2000a and b; Carpenter, 2001). Following post-test activities, the mud pits were commonly allowed to dry out, surveyed for radiation, and in some instances were backfilled with native soils (DOE/NV, 2001).

\subsubsection{Cellar Process}

The main purpose of the cellar was to house the blowout preventer (BOP) equipment. The BOP was a device located at the post-test borehole that could seal off the annular space between the drill pipe and walls of the containment stack to prevent an uncontrolled escape of radioactive gases or liquids (DOE/NV, 2001). The drill rig was set up at a predetermined distance outside of the collapsed area, and the borehole was typically drilled at a 32-degree angle through the bottom of the cellar to the zone of interest soon after the test (LLNL, 1984). The cellars typically consist of a 10-ft diameter corrugated metal pipe that lines a 10- to 12-ft-deep excavation in the ground. A concrete foundation around the perimeter of the cellar is often found at the ground surface. After completion of post-test sampling, the drill pipe is withdrawn and an abandonment valve is closed to seal off the hole. Ten of the CAU 177 cellars have been backfilled with clean fill, and two (CASs 19-23-03 and 20-23-07) have been left open. The boreholes associated with the cellar are under the control of the Borehole Management Program and are not included in the scope of the CAS. Six boreholes have already been plugged, four are currently on the list of candidates for plugback, and two are on a "saved” list for potential future monitoring.

\subsubsection{Physical Setting}

With the exception of CASs 09-09-41 and 09-09-45, which are located in the larger radioactive material area (RMA) in Area 9, all other CASs were posted as Underground RMAs by the Management and Operating Radiation Control (RadCon) organization. Since originally posted, CASs 19-23-02 and 20-23-07 have had Underground RMA postings removed. Accidental releases of radioactivity that occurred during the test, or post-test activities associated with these CASs, although unlikely, may have contributed radiological contamination.

Appendix B provides additional information on physical setting of each CAS. 


\subsection{CAS 08-23-01, Mud Pit and Cellar}

\subsubsection{Description and Location}

The CAS consists of the environmental releases associated with a mud pit and cellar located within a fenced Underground RMA. The site is located approximately $212 \mathrm{ft}$ southeast of the U-8b crater.

The mud pit is open, filled with tumbleweeds, and measures approximately 100 by 40 by $6 \mathrm{ft}$. A large dirt mound related to excavation of the mud pit is located outside of the fencing at the southwest end of the site. The cellar is located approximately $25 \mathrm{ft}$ north of the mud pit and has been backfilled with native soil that forms a small mound above the ground surface. The associated borehole (U-8b PS\#1A) has been plugged by the Borehole Management Program (BN, 2006). A spill of grout or concrete, suspected to have originated from the plugging of the borehole, is located within the northeast end of the mud pit. The spill covers an area approximately 15 by $15 \mathrm{ft}$ and its thickness is unknown. Debris present includes metal fence posts, wooden planks, concrete, and scrap metal. See Figure 2-1 for a diagram of CAS 08-23-01.

\subsubsection{History and Process Knowledge}

The mud pit and cellar of this CAS are associated with post-test drilling of borehole U-8b PS\#1A. Cyathus was the associated underground weapons related test that was conducted by LLNL on March 6, 1970, and resulted in formation of the U-8b crater. No releases were reported for this test. The Baneberry test (U-8d), located in close proximity to CAS 08-23-01, had an accidental release of radioactivity on December 18, 1970. This release may have contributed contamination to the general area (DOE/NV, 2000b).

\subsubsection{Available Characterization Information}

A geophysical survey conducted on April 27, 2005, identified a distinct anomaly attributed to the buried cellar casing. Variations in conductivity throughout the survey area suggest that the area contains no significant subsurface metallic features such as pipelines or debris (Fahringer, 2005).

No samples have been collected at this CAS, and no radiological walkover surveys have been performed. 


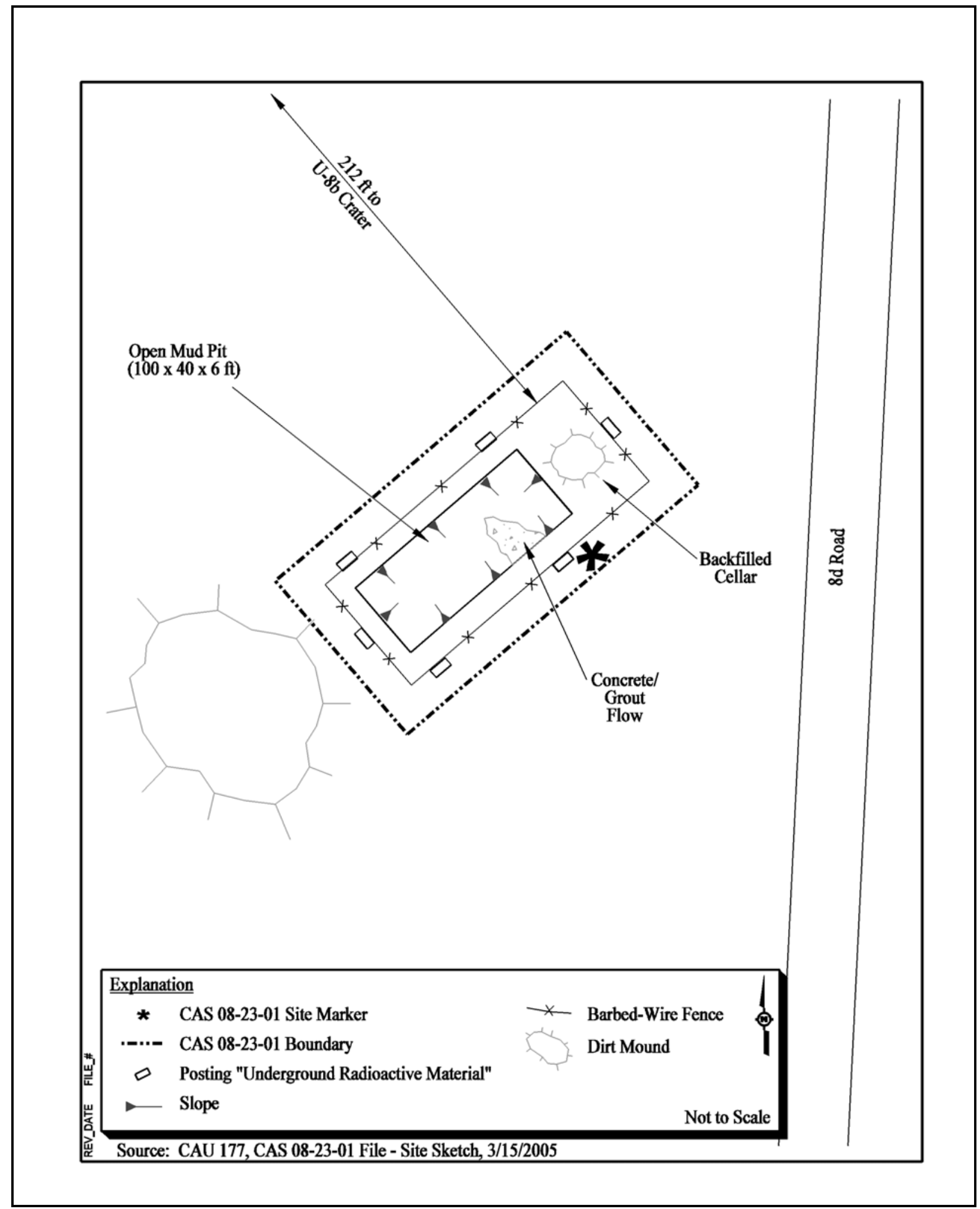

Figure 2-1

Corrective Action Site 08-23-01, Mud Pit and Cellar 


\subsection{CAS 09-09-41, Unknown \#3 Mud Pit/Disposal Area}

\subsubsection{Description and Location}

This site consists of the environmental releases associated with a single mud pit located in Area 9, approximately $300 \mathrm{ft}$ north of the U-9bz ground zero. Rectangular earthen berms surround the mud pit and are approximately 5 to $6 \mathrm{ft}$ above grade. The perimeter of the inside of the berms measures 100 by $50 \mathrm{ft}$. The depth to the base of the mud pit from the top of the berm was visually estimated to be $12 \mathrm{ft}$. The mud pit is partially filled with tumbleweeds; however, there is a cleared area related to a previous sampling effort. The site is located within the B-9A RMA that is posted "Radioactive Materials Area”; however, the pit itself is not posted (SNJV, Date Unknown).

Debris present includes T-posts, partially buried testing cables, small pieces of red brick, and electrical cables that are on the ground surface within $50 \mathrm{ft}$ of the south side of the mud pit. Posted signs near the inactive testing cables read, "Danger Buried Cable 5000 Volts." See Figure 2-2 for a diagram of CAS 09-09-41.

\subsubsection{History and Process Knowledge}

The mud pit of this CAS is categorized as a disposal mud pit that is not associated with a borehole or specific drilling operations. These mud pits may have been created for mixing virgin mud for drilling purposes, or they may have been used for disposal of drill cuttings and fluids generated during the drilling of boreholes.

The exact date when the mud pit was constructed is uncertain. Historical photographs indicate the mud pit was constructed between January 30, 1969, and September 1989 (AAS, 1969; EG\&G, 1989). Historically, the area surrounding CAS 09-09-41 has been extensively used for atmospheric and underground testing and drilling operations (Sorom, 1992).

\subsubsection{Available Characterization Information}

Europium (Eu)-152 was detected above the preliminary action level (PAL) (5.7 picocuries per gram [pCi/g]) in surface soil samples at CAS 09-09-41. The analytical results demonstrate that radiological contamination is distributed throughout the mud pit and is not just limited to the surface. The levels 


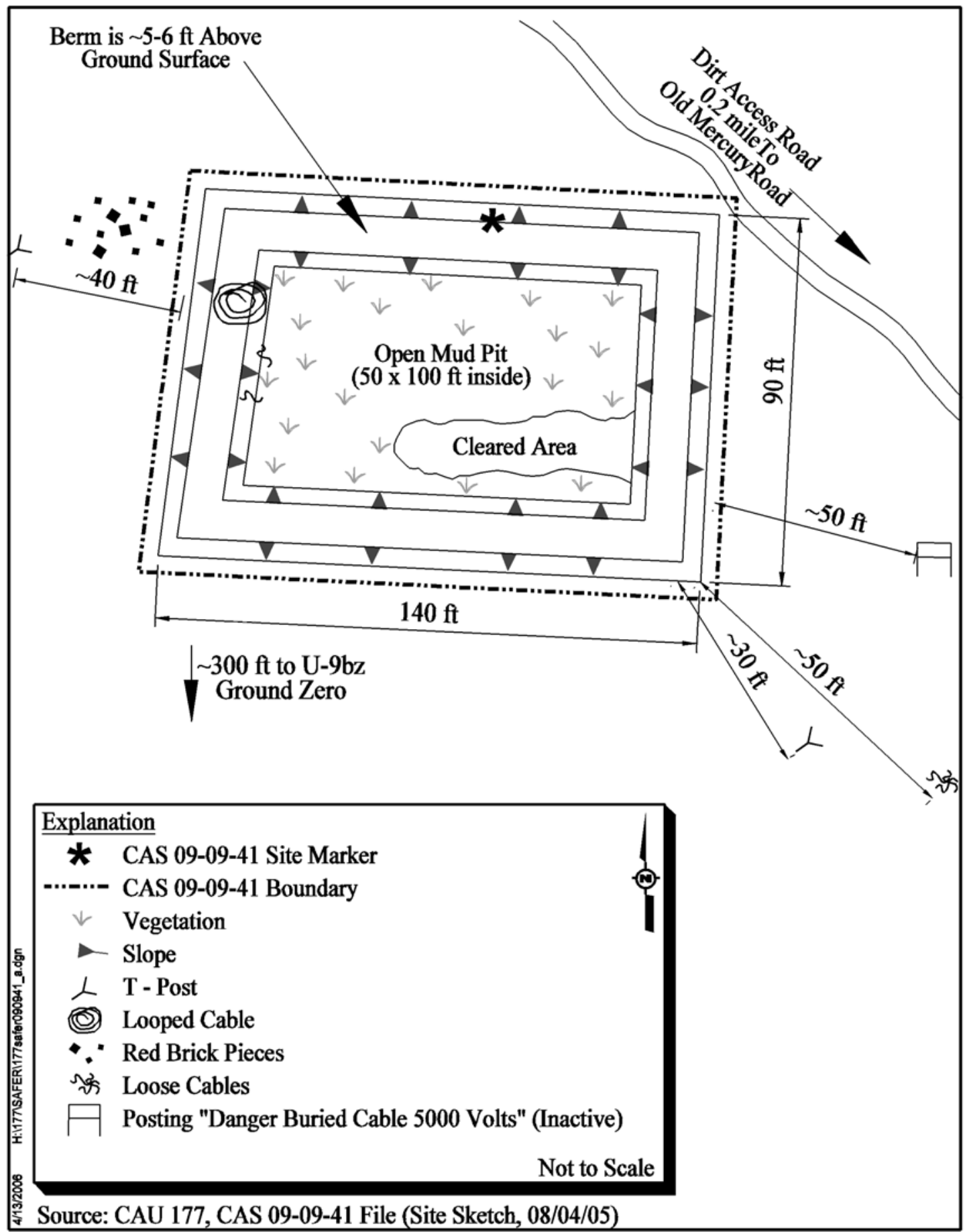

Figure 2-2

Corrective Action Site 09-09-41, Unknown \#3 Mud Pit/Disposal Area 
of Eu-152 in both surface samples ( 0 to 3 inches [in.] bgs and 3 to 6 in. bgs) from the same location demonstrate that contamination was introduced into this area of the mud pit during disposal operations and cannot be attributed solely to fallout from atmospheric testing. None of the other radionuclides analyzed (strontium [Sr]-90, plutonium [Pu]-238, Pu-239, uranium [U]-234, U-235, $\mathrm{U}-238$, cesium [Cs]-137, and lead [Pb]-212) were detected at concentrations exceeding PALs (SNJV, Date Unknown).

Results from a radiological walkover survey indicate that CAS 09-09-41 does not contain radiological contamination of surficial soil at concentrations statistically greater than surficial soil from undisturbed background locations. It is concluded that CAS 09-09-41 poses no significant increased risk to individuals from residual radiological contamination (Nicosia, 2003).

The Nevada Test Site Contaminated Land Areas Report, Volume I reports radiological survey results and contaminated boundaries for the B-9A RMA. The B-9A RMA was surveyed between April 7 and June 4, 1998. The general RMA measures 7,800,000 square feet $\left(\mathrm{ft}^{2}\right)$ and is posted but not fenced, and includes the area surrounding CAS 09-09-41. The area contains survey points reading between 0-20 disintegrations per minute (dpm) alpha. This document also contains results for survey points from a 1994 Aerial Radiation Survey that detected levels of gamma radiation that exceed 240 milliroentgens per hour (mR/hr). The results of this survey indicate that radionuclides in the soil are expected to be residual fission and activation products. Much of the activity is incorporated into trinity glass that is dispersed throughout the site (DOE/NV, 2000a).

\subsection{CAS 09-09-45, U-9bz PS \#1A Mud Pit (1) and Cellar}

\subsubsection{Description and Location}

This site consists of the environmental releases associated with a mud pit and cellar located approximately $300 \mathrm{ft}$ northeast of the U-9bz ground zero in Area 9. This CAS is not fenced or posted with radiological signs. The mud pit is open but contains abundant vegetation. It measures approximately 80 by $25 \mathrm{ft}$ and its base is approximately 4 to $6 \mathrm{ft}$ bgs. A large dirt mound that measures approximately 50 by 35 by $15 \mathrm{ft}$ is located at the south end of the mud pit and is likely related to its excavation. The cellar is located approximately $40 \mathrm{ft}$ north of the mud pit and has been backfilled with pea gravel that is level with the ground surface. The cellar casing is exposed and 
measures $10 \mathrm{ft}$ in diameter. Drill stemming in the cellar is also exposed and has been plugged with grout, which overflows the stemming and has spilled onto the ground surface. A second larger grout spill, measuring approximately 65 by $30 \mathrm{ft}$, is located approximately $85 \mathrm{ft}$ southwest of the cellar. A 40-by-1-ft trench that is up to 6 in. deep runs south from the cellar to the associated mud pit. A second 50-by 8-in. trench that is several inches deep runs from near the north end of the mud pit to the southwest toward a large grout spill. Debris includes T-posts; downed and degraded yellow rope; and miscellaneous wood, metal, and plastic debris. See Figure 2-3 for a diagram of CAS 09-09-45.

\subsubsection{History and Process Knowledge}

The mud pit and cellar of this CAS are associated with post-test drilling of borehole U-9bz PS \#1A. This borehole has been plugged by the Borehole Management Program (BN, 2006). Biggin was the associated underground weapons related test that was conducted by LLNL on January 30, 1969 and resulted in formation of the U-9bz crater. No releases were reported for this test (DOE/NV, 1996). Corrective Action Site 09-09-45 is also located in the B-9A RMA described above for CAS 09-09-41 (SNJV, Date Unknown).

\subsubsection{Available Characterization Information}

Plutonium-239 and Eu-152 were detected above PALs (12.70 pCi/g and 5.7 pCi/g, respectively) in surface and near-surface soil samples at CAS 09-09-45. The concentrations of these two radionuclides at the various depths demonstrate that elevated Pu-239 and Eu-152 may be widespread within the mud pit and is not entirely related to fallout. Contamination present at this CAS is likely attributed to the presence of trinity glass that was generated during the series of atmospheric tests conducted at the site B-9A, approximately $772 \mathrm{ft}$ northwest of the CAS. None of the other radionuclides analyzed (Sr-90, Pu-238, U-234, U-235, U-238, Cs-137, and Pb-212) were detected at concentrations exceeding PALs (SNJV, Date Unknown).

No geophysical or walkover radiological surveys have been completed for this CAS. 


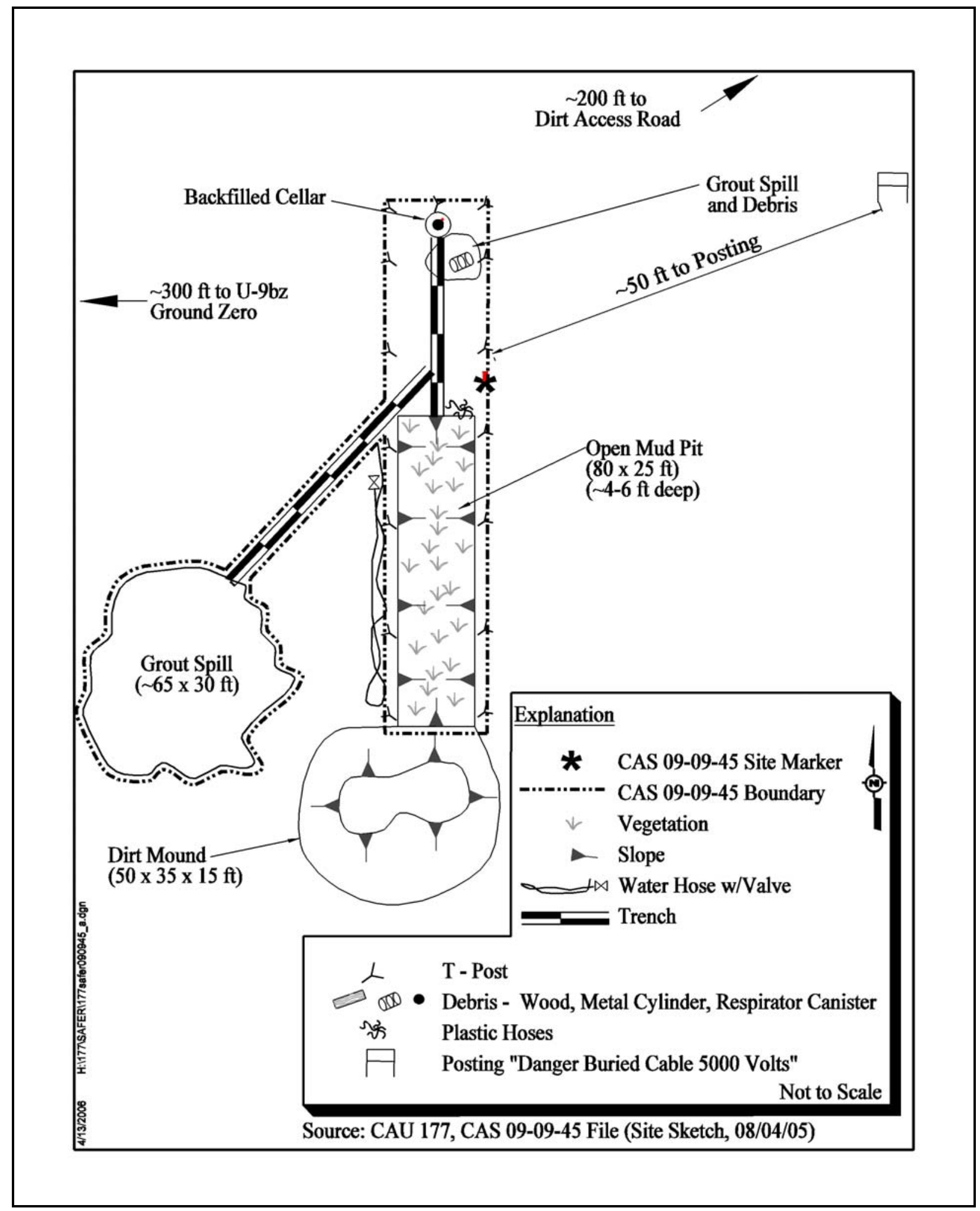

Figure 2-3

Corrective Action Site 09-09-45, U-9bz PS \#1A Mud Pit (1) and Cellar 


\subsection{CAS 09-23-05, Mud Pit and Cellar}

\subsubsection{Description and Location}

The site consists of the environmental releases associated with a mud pit and cellar within a fenced Underground RMA that is located approximately $90 \mathrm{ft}$ west of the U-9ch crater in Area 9. The mud pit has been backfilled and measures 45 by $43 \mathrm{ft}$. The boundaries of the mud pit are obscure; however, the dimensions are based on observations of a slightly subsided area believed to represent the backfilled mud pit. The cellar has been backfilled with native soil, level with the ground surface, and contains drill stemming that extends about $1 \mathrm{ft}$ above grade. The cellar casing is exposed, but it appears that the concrete foundation has been removed. Debris present includes yellow rope just west of the mud pit and pieces of scrap metal. See Figure 2-4 for a diagram of CAS 09-23-05.

\subsubsection{History and Process Knowledge}

The mud pit and cellar of this CAS are associated with post-test drilling of borehole U-9ch PS \#1A. This borehole has been plugged by the Borehole Management Program (BN, 2006). Cathay was the associated underground weapons related test that was conducted by LLNL on October 8, 1971, and resulted in formation of the U-9ch crater. No releases were reported for this test (DOE/NV, 1996).

\subsubsection{Available Characterization Information}

Results of a walkover geophysical survey have identified a distinct anomaly due to the partially buried cellar. The data indicate additional pieces of metallic debris are likely present in the shallow subsurface but not in significant size or quantity. The survey also suggests that the area contains no significant subsurface metallic features such as pipelines or debris (Fahringer, 2005).

No sampling or radiological walkover surveys have been conducted at this CAS.

\subsection{CAS 09-23-08, Mud Pit and Cellar}

\subsubsection{Description and Location}

The site consists of the environmental releases associated with a mud pit and cellar within a fenced Underground RMA located in Area 9, approximately $75 \mathrm{ft}$ east of Old Mercury Highway and 


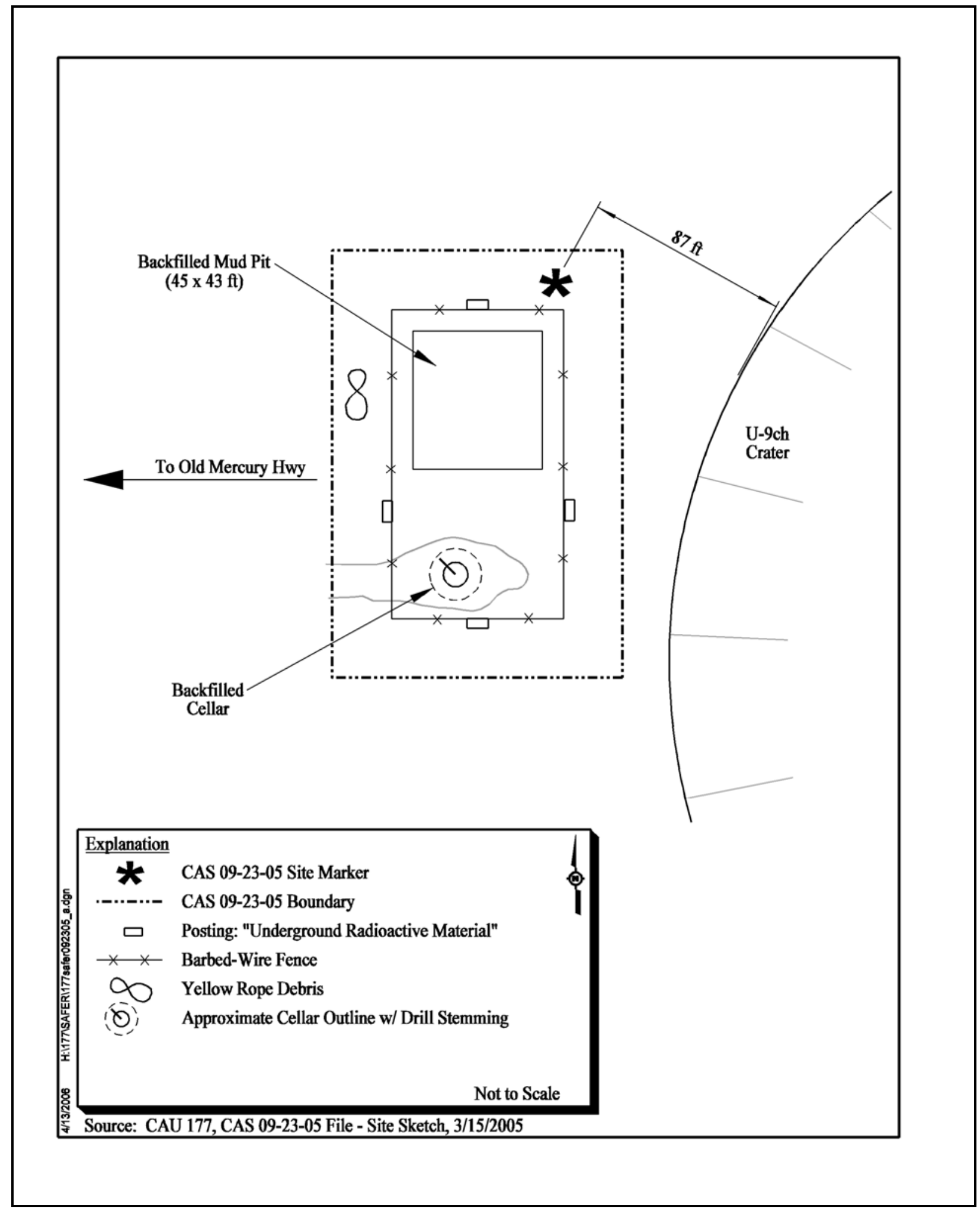

Figure 2-4

Corrective Action Site 09-23-05, Mud Pit and Cellar 
approximately $75 \mathrm{ft}$ west of the U-9itsw22 crater. The mud pit measuring 65 by $35 \mathrm{ft}$ has been backfilled and is slightly subsided compared to the surrounding ground surface. A dirt mound related to the excavation is located at the north end of the mud pit. The cellar has been backfilled with native soil that is level with the ground surface, and its casing and concrete foundation are exposed. No debris has been identified. See Figure 2-5 for a diagram of CAS 09-23-08.

\subsubsection{History and Process Knowledge}

The mud pit and cellar are associated with post-test drilling of borehole U-9itsw22 PS \#1A. This borehole has been plugged by the Borehole Management Program (BN, 2006). Haplopappus was the associated underground weapons related test that was conducted by LLNL June 28, 1972, and resulted in formation of the U-9itsw22 crater. No releases were reported for this test (DOE/NV, 1996 and 2000b).

\subsubsection{Available Characterization Information}

Results of a walkover geophysical survey have identified an anomaly due to the partially buried cellar. Another distinct anomaly measuring approximately 3 by $7 \mathrm{ft}$ is located near the center of the south end of the mud pit. The source of this anomaly is suspected to be buried metallic debris. The data indicate additional pieces of metallic debris are likely present in the shallow subsurface but not in significant size or quantity. Variations in conductivity throughout the survey area suggest that the area contains no significant subsurface metallic features such as pipelines.

No sampling or radiological walkover surveys have been conducted at this CAS.

\subsection{CAS 09-23-09, U-9itsx20 PS\#1A Cellar}

\subsubsection{Description and Location}

The site consists of the environmental releases associated with a cellar located in Area 9, $100 \mathrm{ft}$ northeast of the U-9itsx20 crater. The cellar casing is exposed within a concrete foundation and has been backfilled level to the ground surface. The cellar is located within a 50- by $36-\mathrm{ft}$ fenced Underground RMA. No debris present at this CAS. See Figure 2-6 for a diagram of CAS 09-23-09. 


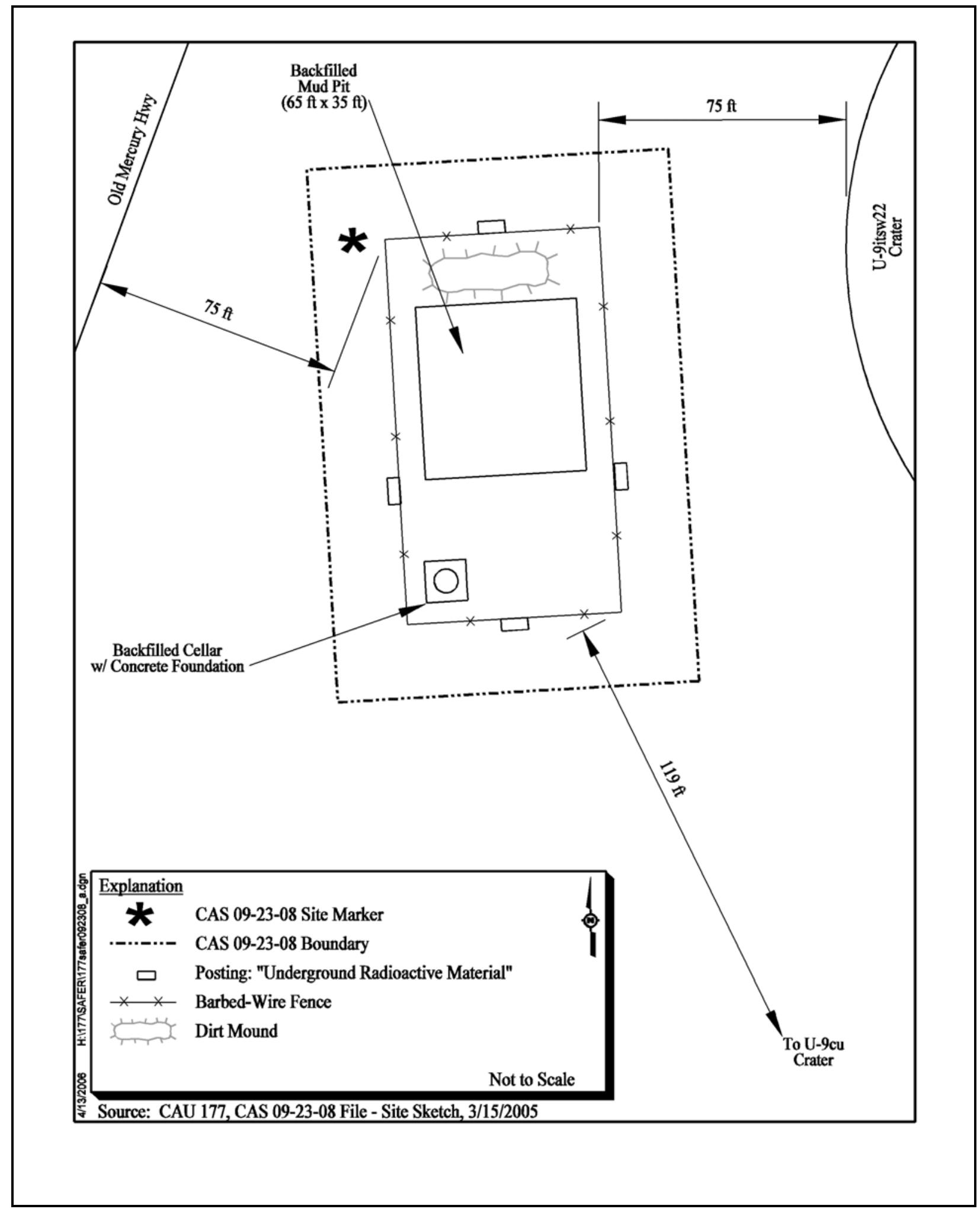

Figure 2-5

Corrective Action Site 09-23-08, Mud Pit and Cellar 


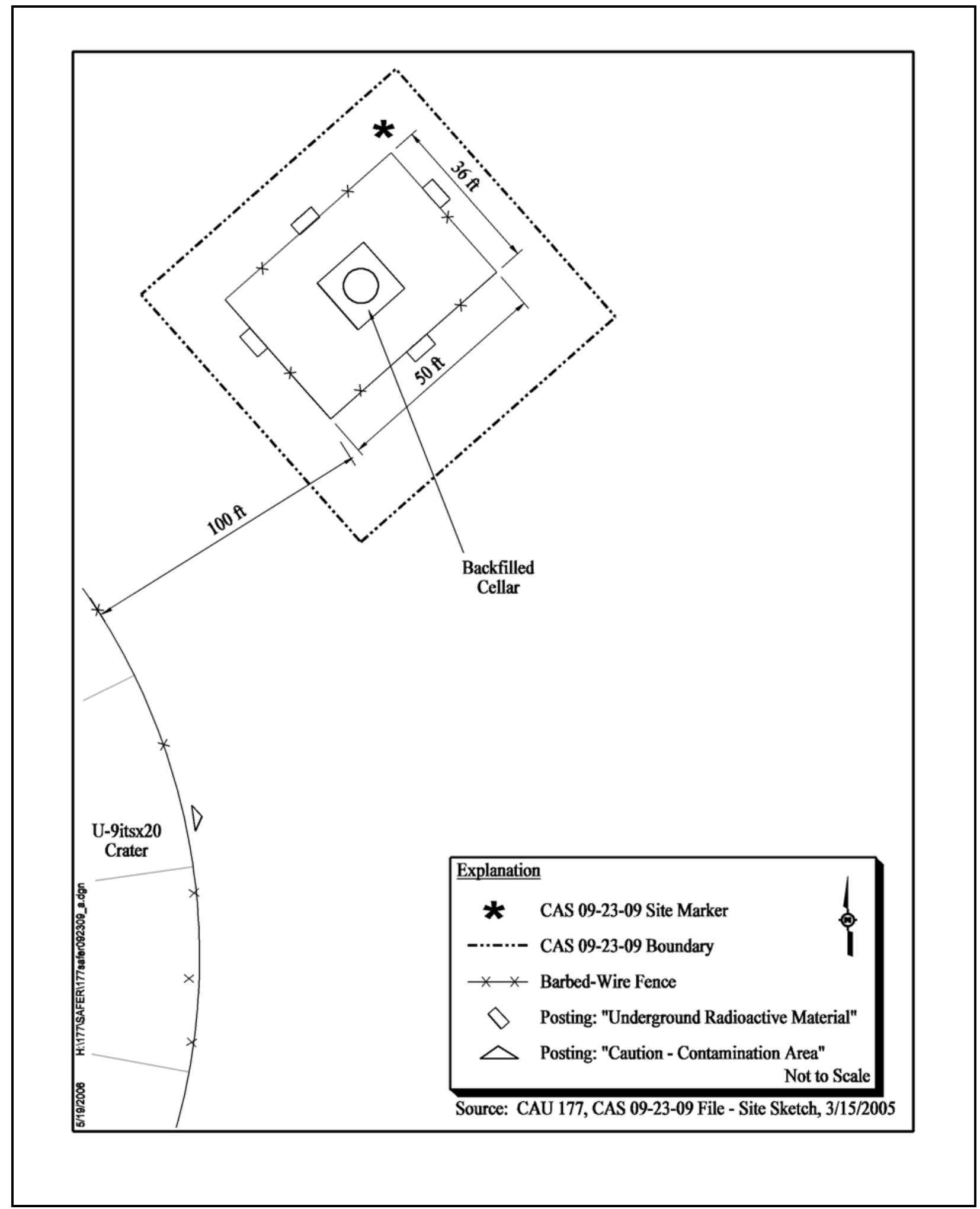

Figure 2-6

Corrective Action Site 09-23-09, U-9itsx20 PS\#1A Cellar 


\subsubsection{History and Process Knowledge}

The cellar is associated with post-test drilling of borehole U-9itsx20 PS \#1A. This borehole has been plugged by the Borehole Management Program (BN, 2006). Hod-B (Red) was the associated underground weapons related test that was conducted by LLNL on May 1, 1970, and resulted in formation of the U-9itsx20 crater. No releases were reported for this test (DOE/NV, 1996 and 2000b).

\subsubsection{Available Characterization Information}

Results of a walkover geophysical survey identified a distinct anomaly located southeast of the fenced area; however, this feature is outside the scope of the CAS (Fahringer, 2005).

No sampling or radiological walkover surveys have been conducted at this CAS.

\subsection{CAS 10-23-02, Mud Pit and Cellar}

\subsubsection{Description and Location}

The site consists of the environmental releases associated with a mud pit and two cellars within a fenced Underground RMA located in Area 8, approximately $100 \mathrm{ft}$ north of the U-10am3 ground zero. The open mud pit measures 41 by 21 by $5 \mathrm{ft}$ and contains vegetation along its walls and base. The cellars are located $20 \mathrm{ft}$ west and approximately $50 \mathrm{ft}$ north of the mud pit, respectively. The cellars have been backfilled with native soil that forms a small mound above the ground surface. The casing of the west cellar and the concrete foundation of both cellars are exposed. Debris present includes potential leftover drill stemming, scrap corrugated metal, water hoses, a pile of corroded yellow rope, and numerous cables. See Figure 2-7 for a diagram of CAS 10-23-02.

\subsubsection{History and Process Knowledge}

The mud pit and cellars are associated with post-test drilling of the U-10am3 PS \#1A and U-10am4 PS \#1A boreholes. These boreholes have not been plugged but are candidates for plugback through the Borehole Management Program (BN, 2006). Tun-C and Tun-D (part of the Tun-A, B, C, and D simultaneous tests) are the associated underground tests that were conducted by LLNL on December 10, 1969 (DOE/NV, 2000b). 


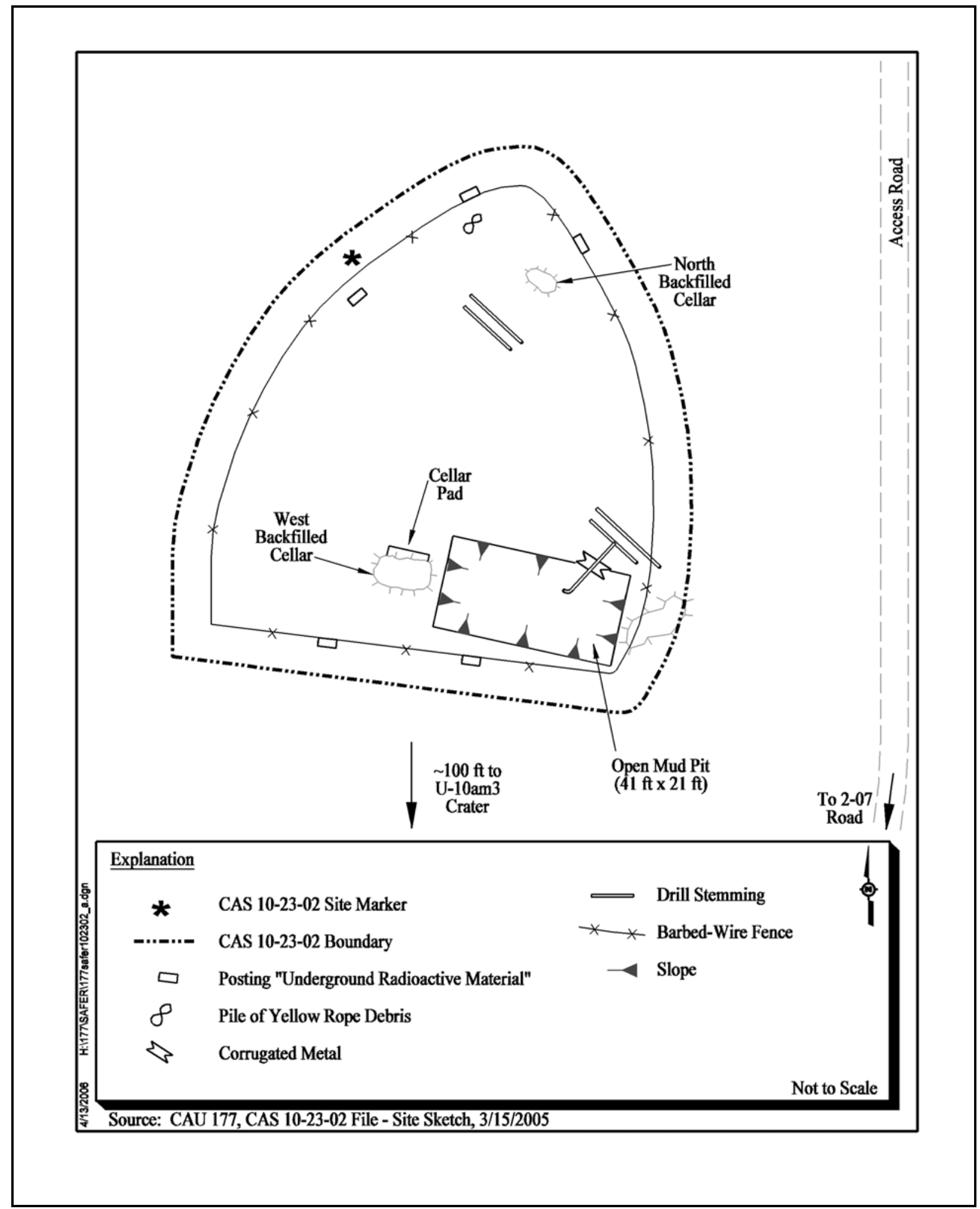

Figure 2-7

Corrective Action Site 10-23-02, Mud Pit and Cellar 
A test release for the Tun-B and -C tests were reported. After post-test drilling began, another release was reported as a result of gas sampling operations. These releases began on December 11, 1969, and lasted for two days (DOE/NV, 1996). It is unknown whether these releases have affected the associated and nearby post-test mud pit and cellars of CAS 10-23-02.

\subsubsection{Available Characterization Information}

There have been no sampling, geophysical, or radiological walkover surveys conducted at this CAS.

\subsection{CAS 10-23-03, Mud Pit and Cellar}

\subsubsection{Description and Location}

This site consists of the environmental releases associated with an open mud pit and backfilled cellar within a fenced Underground RMA located in Area 8, approximately $200 \mathrm{ft}$ north of the U-10am1 crater. The mud pit measures 42 by $17 \mathrm{ft}$ and is approximately $5 \mathrm{ft}$ deep. The base of the pit is covered with vegetation. A dirt mound located at the east end of the mud pit is believed to be associated with the excavation. The cellar is located $26 \mathrm{ft}$ west of the mud pit and has been backfilled with native soil to approximately $2 \mathrm{ft}$ above grade, forming a mound. A utility pipe, which is believed to be connected to drill stemming in the borehole, extends approximately $3 \mathrm{ft}$ above grade. The cellar casing and concrete foundation are partially exposed under the mound.

A metal 12-in. diameter, 18-in. long container is located on the ground surface approximately $10 \mathrm{ft}$ east of the cellar. The use and contents of this container are unknown; however, a pressure gauge on it suggests that it may have been used to regulate water or gas pressure. Other debris present includes a rusted metal staircase, a pile of corroded yellow rope, a pile of coiled barbed wire, and rubber hoses that are partially buried by soil. See Figure 2-8 for a diagram of CAS 10-23-03.

\subsubsection{History and Process Knowledge}

The mud pit and cellar are associated with post-test drilling of the U-10am1 PS \#1A borehole, which has not been plugged, but is a candidate for plugback through the Borehole Management Program (BN, 2006). Tun-A (part of the Tun-A, B, C, and D simultaneous tests) is the associated underground test that was conducted by LLNL on December 10, 1969 (DOE/NV, 2000b). 


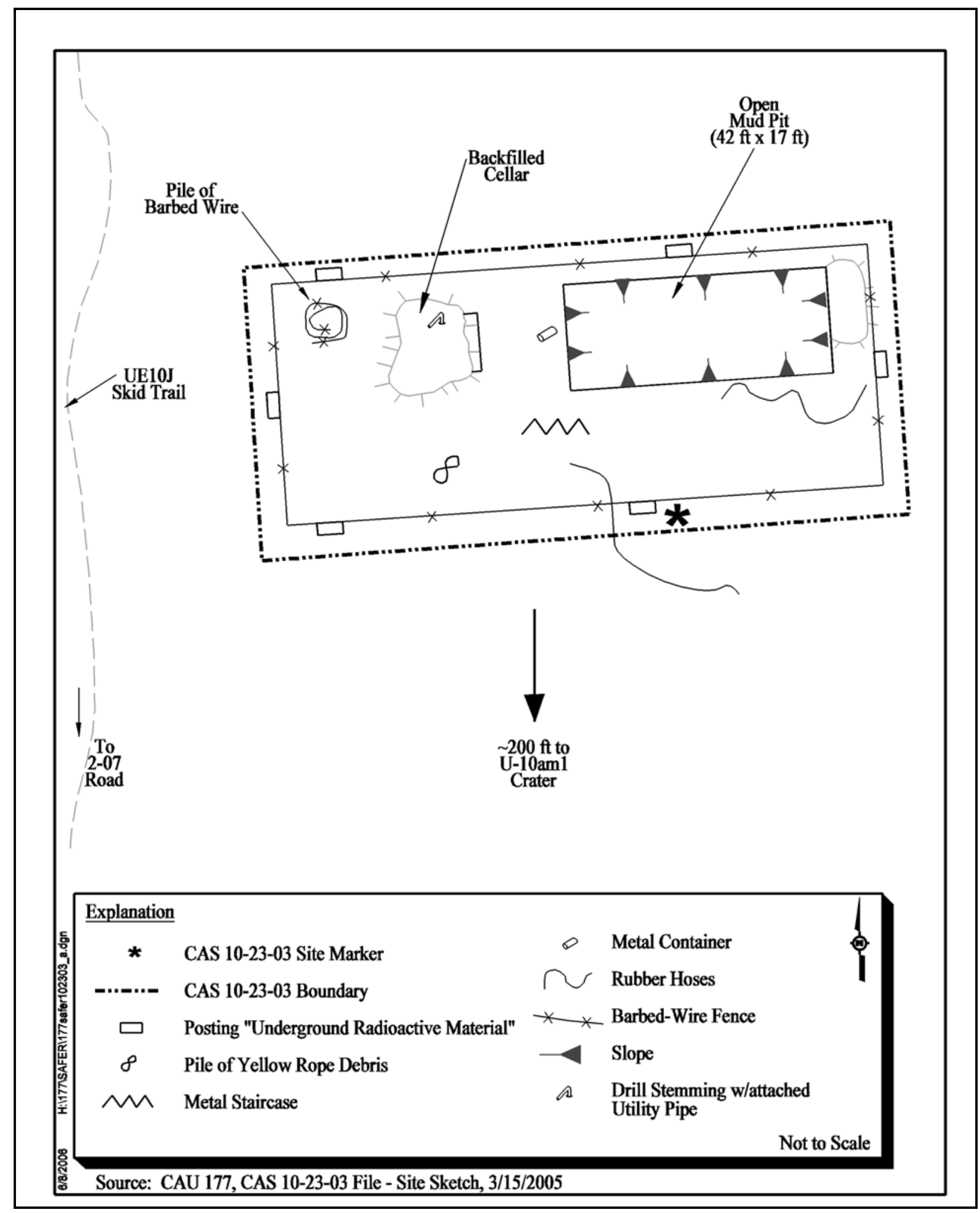

Figure 2-8

Corrective Action Site 10-23-03, Mud Pit and Cellar 
Test-related releases of radiological effluent that may have impacted this CAS are described above for CAS 10-23-02.

\subsubsection{Available Characterization Information}

There have been no sampling, geophysical, or radiological walkover surveys conducted at this CAS.

\subsection{CAS 19-23-01, Mud Pit and Cellar}

\subsubsection{Description and Location}

The site consists of the environmental releases associated with a mud pit and cellar located in Area 19, approximately $850 \mathrm{ft}$ northeast of U-19ys crater. A dirt mound located approximately $40 \mathrm{ft}$ east of the cellar is believed to be the location of the backfilled mud pit. This mound measures 90 by $31 \mathrm{ft}$ and extends approximately $5 \mathrm{ft}$ above grade. At the east end of the suspected mud pit is a subsided area that contains dry mud and partially buried debris including scrap plastic, wood, metal, and a steel beam. It is unknown whether the mud is natural or drilling mud. The cellar is located approximately $40 \mathrm{ft}$ west of the mud pit and has been backfilled with soil that is level with the ground surface. The cellar is cased with corrugated metal, which opens to the east facing the associated mud pit. Only the cellar is fenced and posted "Underground RMA.” A single “Controlled Area” posting is located on the east side of the cellar. See Figure 2-9 for a diagram of CAS 19-23-01.

\subsubsection{History and Process Knowledge}

The mud pit and cellar are associated with post-test drilling of the U-19ys PS \#1D borehole, which has been plugged through the Borehole Management Program (BN, 2006). Panir is the associated underground test that was conducted by LLNL on August 31, 1978, and resulted in the U-19ys crater. No releases were reported for this test (DOE/NV, 2000b).

\subsubsection{Available Characterization Information}

Results of a walkover geophysical survey have identified two surface metallic features and additional small anomalies that surround the fenced cellar; however, none of the anomalies appear to be of significant size or depth to warrant further investigation. Due to the small size and likely interference 


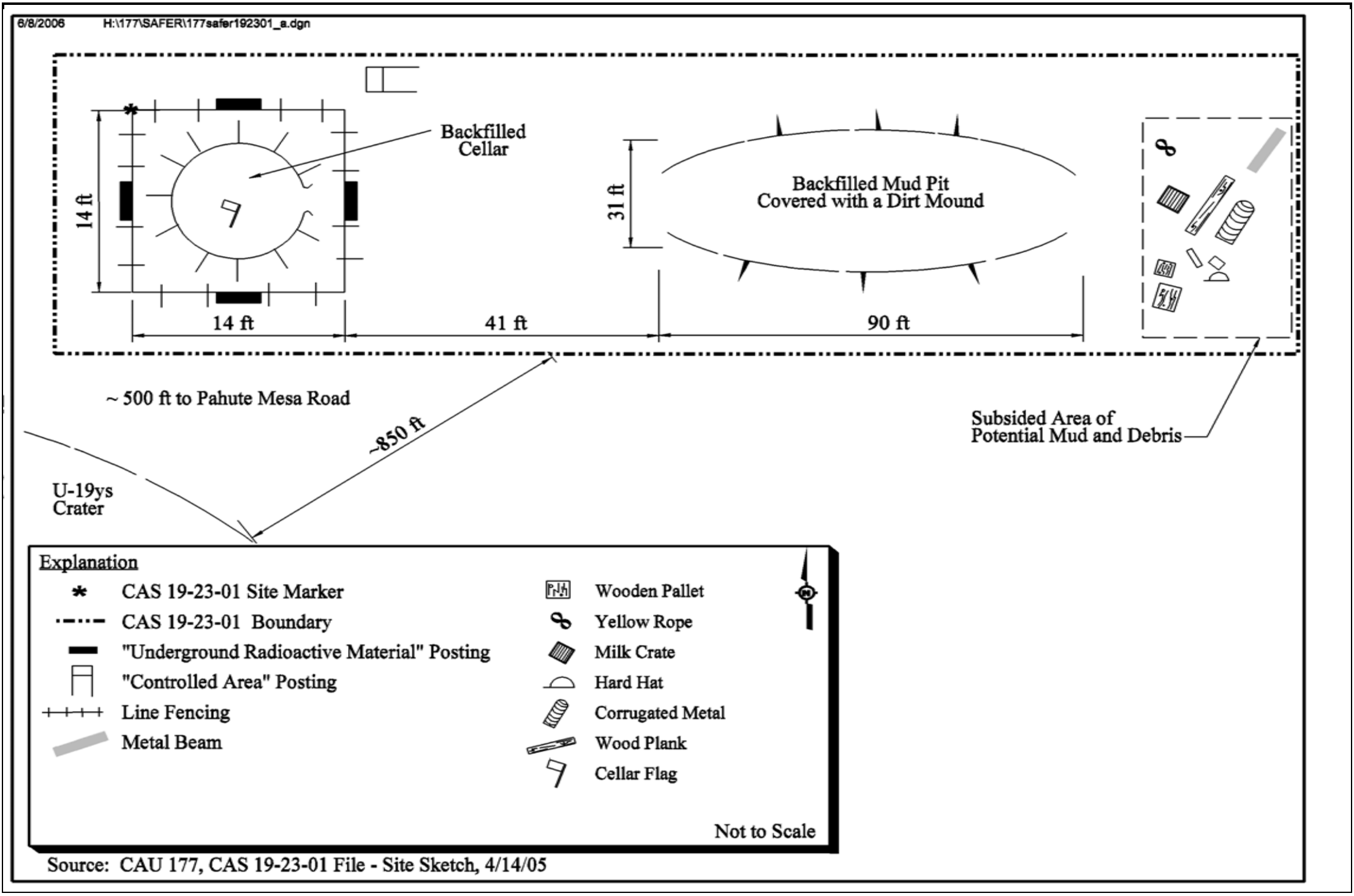

Figure 2-9

Corrective Action Site 19-23-01, Mud Pit and Cellar 
from the metal fence, data were not collected within the fenced area where the cellar is located. No additional metallic piping or utilities within the surveyed area were identified (Fahringer, 2005).

There have been no sampling or radiological walkover surveys conducted at this CAS

\subsection{CAS 19-23-02, Cellar and Waste Storage Area}

\subsubsection{Description and Location}

The site consists of the environmental releases associated with a cellar located in Area 19, $978 \mathrm{ft}$ north of the U-19ay ground zero. There is no evidence of the waste storage area originally described by Reynolds Electrical \& Engineering Co., Inc. (REECo) (REECo, 1991), and the fencing and radiological postings have also been removed. The cellar is located $28 \mathrm{ft}$ west of its associated backfilled mud pit, which is a separate CAS (19-09-20) that is being investigated in CAU 531. The cellar has been backfilled to be level with the ground surface and its casing opens in the direction of the mud pit. There is no debris present at this CAS. See Figure 2-10 for a diagram of CAS 19-23-02.

\subsubsection{History and Process Knowledge}

The cellar is associated with post-test drilling of the U-19ay PS \#1A borehole, which has been plugged through the Borehole Management Program (BN, 2006). Amarillo is the associated underground test that was conducted by LANL on June 27, 1989. No releases were reported for this test (DOE/NV, 1996 and 2000b).

This CAS was originally identified on October 2, 1990, to be a posted radiation contamination area, which includes a small mud pit, covered cellar, and waste storage area (REECo, 1991). However, a May 25, 1995, field visit reported that the radiological postings and waste had been removed. It is therefore believed that backfilling, and removal of postings and waste occurred some time between 1990 and 1995. It was common practice to remove radiological postings if a radiological survey did not detect elevated readings. This was likely the case at CAS 19-23-02.

\subsubsection{Available Characterization Information}

Results of the geophysical survey have determined two surface metallic features. The first anomaly is that of the backfilled cellar and the second is located approximately 8 meters to the south and is 


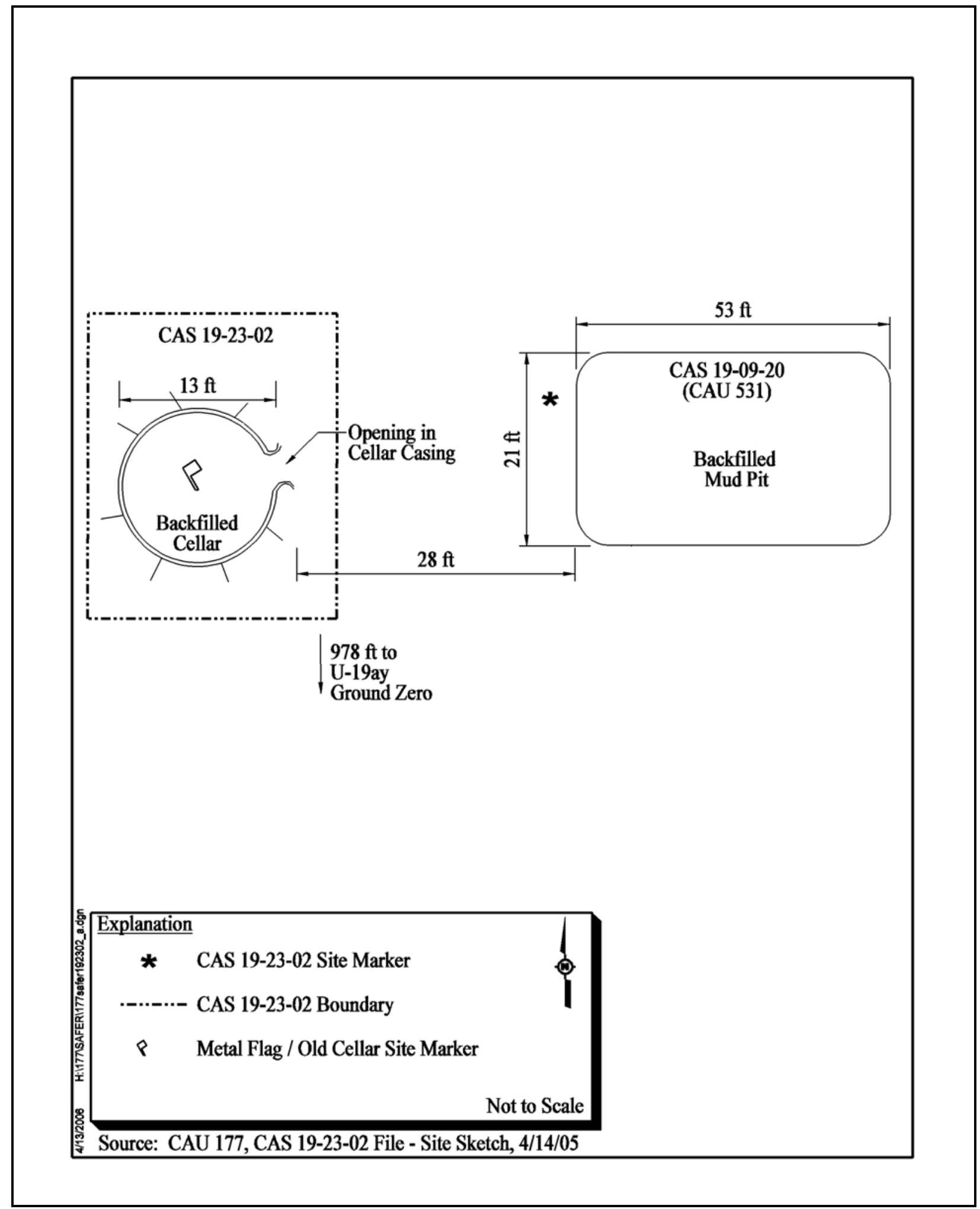

Figure 2-10

Corrective Action Site 19-23-02, Cellar and Waste Storage Area 
outside the scope of this CAS. No additional metallic piping or utilities within the surveyed area were identified (Fahringer, 2005).

There have been no sampling or radiological walkover surveys conducted at this CAS.

\subsection{CAS 19-23-03, Cellar with Casing}

\subsubsection{Description and Location}

The site consists of the environmental releases associated with an open cellar within a 17-by-16-ft fenced Underground RMA located in Area 19, 300 yards from U-19ac ground zero. The mud pit associated with this cellar is being investigated as CAS 19-09-28 as part of CAU 533. The cellar cavity is lined with corrugated metal and contains drill stemming oriented at an angle that extends approximately $3 \mathrm{ft}$ above grade. The stemming has been welded to two stability bars attached to the inside of the cellar wall. A wooden ladder that is oriented upright against the inside of the cellar was used to estimate that the cellar is $12 \mathrm{ft}$ deep. The base of the cellar is covered with soil and miscellaneous pieces of debris. Debris present includes a wooden sawhorse next to two large metal storage boxes that rest on a trailer located just north of the cellar. An area southeast of the cellar is being used to store drill stemming on the ground. See Figure 2-11 for a diagram of CAS 19-23-03.

\subsubsection{History and Process Knowledge}

The cellar is associated with post-test drilling of the U-19ac PS \#1A borehole, which is a candidate for plugback through the Borehole Management Program (BN, 2006). Tierra is the associated underground test that was conducted by LLNL on December 15, 1984. A late-time seepage release detected on site only was reported for the Tierra test. The seepage occurred intermittently between December 26, 1984, and January 4, 1986. (DOE/NV, 1996).

\subsubsection{Available Characterization Information}

There have been no sampling, radiological, or geophysical walkover surveys conducted at this CAS. 


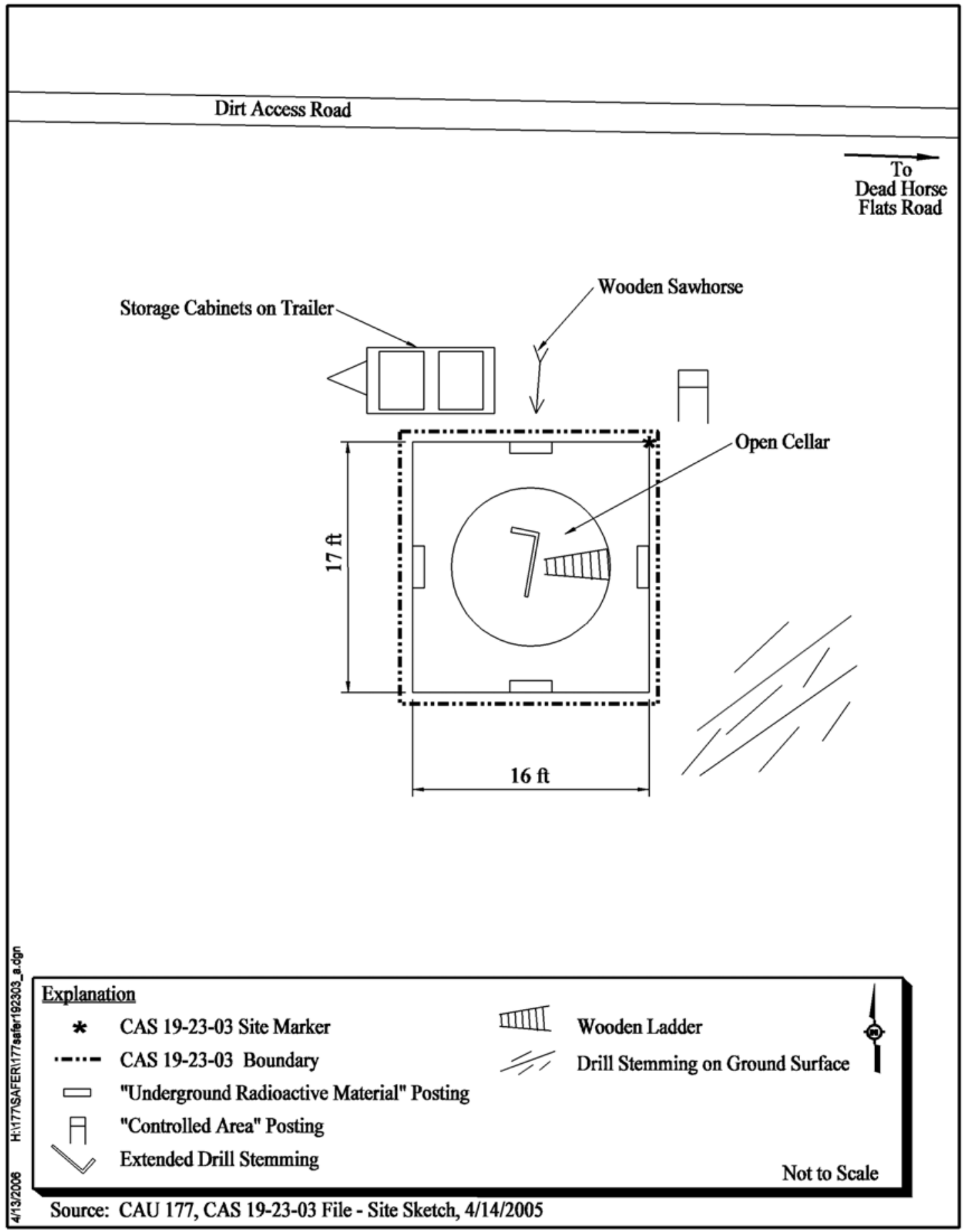

Figure 2-11

Corrective Action Site 19-23-03, Cellar with Casing 


\subsection{CAS 20-23-07, Cellar}

\subsubsection{Description and Location}

The site consists of the environmental releases associated with a cellar located in Area 20, approximately $750 \mathrm{ft}$ south of the U-20bd ground zero. The radiation contamination signs and fence that surrounded the post-test pad area as originally photographed by REECo are no longer present. The baker tank pictured in the REECo photograph has also been removed (REECo, 1991). The cellar is located $23 \mathrm{ft}$ east of its associated mud pit, which is included in CAU 533, CAS 20-09-26. The cellar is open, and contains drill stemming that extends approximately $2 \mathrm{ft}$ above the base of the cellar and is oriented at an angle. The depth to the base of the cellar is approximately $10 \mathrm{ft}$. The floor of the cellar is covered with soil and contains several pieces of miscellaneous debris. The cellar is surrounded by orange snow fencing that measures an 18 by $16 \mathrm{ft}$ area and has a "Caution Cellar 20BD” sign attached to it. A steel tower approximately $15 \mathrm{ft}$ high is adjacent to the cellar and is anchored to the ground by guy wires, two of which are in the snow-fenced cellar area. Two wooden planks partially rest over the east side of the cellar opening. See Figure 2-12 for a diagram of CAS 20-23-07.

\subsubsection{History and Process Knowledge}

The cellar is associated with post-test drilling of the U-20bd PS \#1A borehole, which has not yet been plugged by the Borehole Management Program (BN, 2006). Bullion is the associated underground test that was conducted by LLNL on June 13, 1990 (DOE/NV, 2000b).

\subsubsection{Available Characterization Information}

There have been no sampling, geophysical, or radiological walkover surveys for this CAS. 


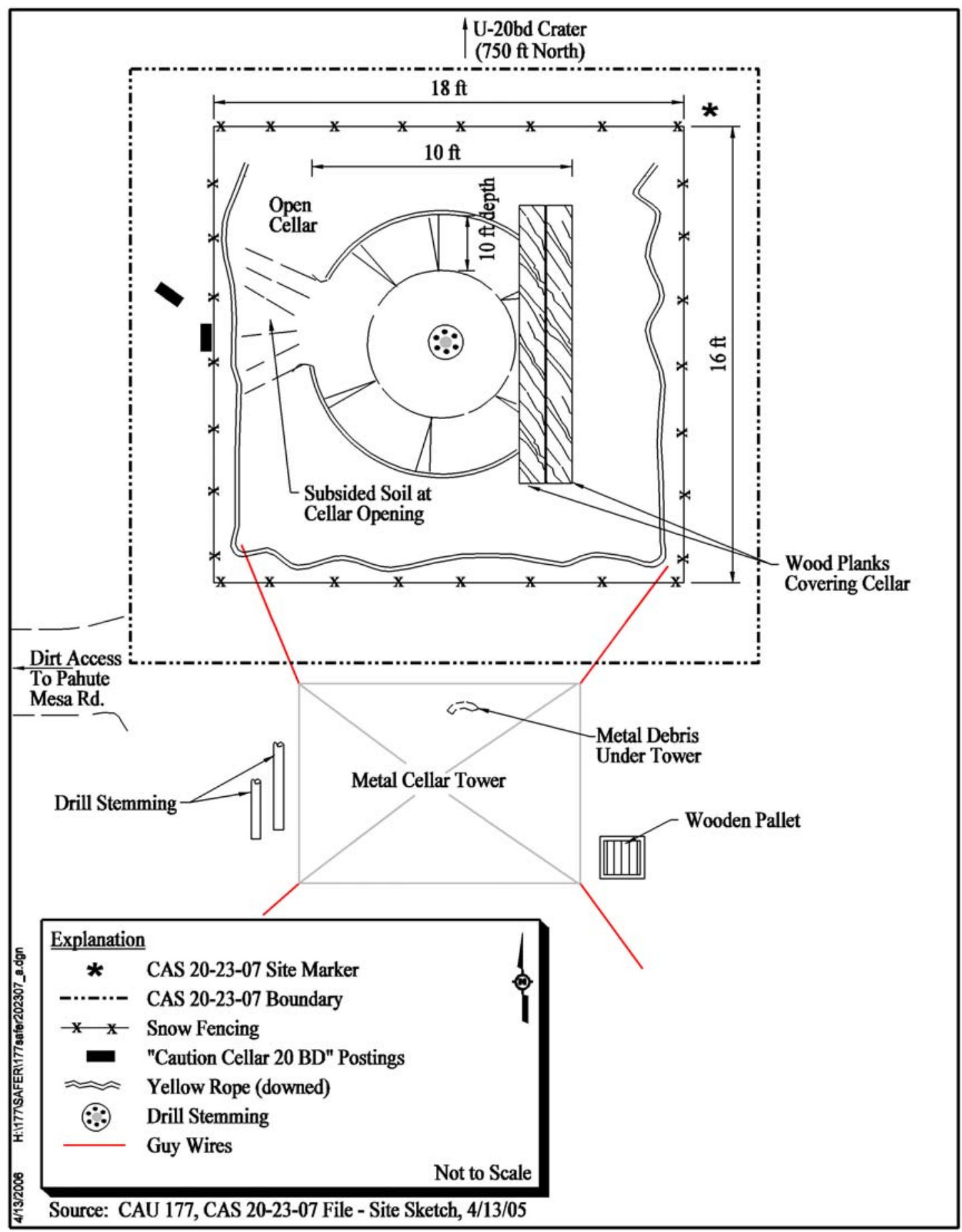

Figure 2-12

Corrective Action Site 20-23-07, Cellar 


\subsection{Data Quality Objectives}

\subsection{Summary of DQO Analysis}

This section contains a summary of the DQO process that is presented in Appendix B. The DQO process is a strategic planning approach based on the scientific method that is designed to ensure that the data collected will provide sufficient and reliable information to identify, evaluate, and technically defend the recommendation of viable corrective actions (e.g., NFA, clean closure, or closure in place).

The DQO strategy for CAU 177 was developed at a meeting on February 21, 2006. The DQOs were developed to identify data needs, clearly define the intended use of the environmental data, and design a data collection program that will satisfy these purposes. During the DQO discussions for this CAU, the informational inputs or data needs to resolve problem statements and decision statements were documented.

The problem statement for CAU 177 is: "Existing information on the nature and extent of potential contamination is insufficient to validate the assumptions used to select the corrective action alternatives of NFA or closure in place, or to verify that closure objectives were met." To address this question, the resolution of two decision statements is required:

- Decision I: “Is any COC present in environmental media within a mud pit or cellar?” For the judgmental sampling design, any analytical result for a COPC above the FAL will result in that COPC being designated as a COC. For the probabilistic sampling design, any COPC that has a 95 percent upper confidence limit (UCL) of the average exceeding the FAL will result in that COPC being designated as a COC.

- Decision II: "Is sufficient information available to confirm that closure objectives were met?" Sufficient information is defined to include:

- Identifying the lateral and vertical extent of COC contamination in media, if present

- The information needed to characterize investigation derived waste (IDW) for disposal

- The information needed to determine remediation waste types 
The presence of a COC would require a corrective action. A corrective action may also be necessary if there is a potential for wastes that are present at a site to impose COCs into site environmental media if the wastes were to be released. To evaluate the potential for site wastes to result in the introduction of a COC to the surrounding environmental media, the following conservative assumptions were made:

- That any containment of the wastes would fail at some point and the wastes would be released to the surrounding media.

- That the resulting concentration of contaminants in the surrounding media would be equal to the concentration of contaminants in the waste.

- That any liquid waste contaminant concentrations exceeding the Resource Conservation and Recovery Act (RCRA) toxicity characteristic concentration would result in COCs in the surrounding media.

Waste solids containing a contaminant exceeding an equivalent FAL concentration would be considered to be potential source material and would require a corrective action. Waste liquids with contaminant concentrations exceeding an equivalent toxicity characteristic action level would be considered to be potential source material and would require a corrective action.

Decision I samples will be submitted to analytical laboratories for the analyses listed in Table 3-1. If any stains or other indicators of contamination are identified at mud pits, then samples will be submitted for all the analyses listed in Table 3-1. Decision II samples will be submitted for the analysis of all unbounded COCs. In addition, samples will be submitted for analyses as needed to support waste management or health and safety decisions.

The data quality indicators (DQIs) of precision, accuracy, representativeness, completeness, comparability, and sensitivity needed to satisfy DQO requirements are discussed in Section 7.2. Laboratory data will be assessed in the Closure Report to confirm or refute the conceptual site model (CSM) and determine whether the DQO data needs were met.

To satisfy the DQI of sensitivity (presented in Section 7.2.6), the analytical methods must be sufficient to detect contamination that is present in the samples at concentrations equal to the corresponding FALs. Analytical methods and minimum detectable concentrations (MDCs) for each CAU 177 COPC are provided in Tables 7-2 and 7-3. The MDC is the lowest concentration of a 
Table 3-1

Analytical Program ${ }^{a}$

\begin{tabular}{|c|c|c|}
\hline Analyses $^{b}$ & Mud Pits & Cellars \\
\hline \multicolumn{3}{|c|}{ Organic COPCs } \\
\hline Total Petroleum Hydrocarbons-Diesel-Range Organics & --- & $\mathrm{X}$ \\
\hline Total Petroleum Hydrocarbons-Gasoline-Range Organics & --- & $\mathrm{X}$ \\
\hline Polychlorinated Biphenyls & --- & $\mathrm{X}$ \\
\hline Semivolatile Organic Compounds ${ }^{c}$ & --- & $\mathrm{X}$ \\
\hline Volatile Organic Compounds ${ }^{c}$ & --- & $X$ \\
\hline \multicolumn{3}{|c|}{ Inorganic COPCs } \\
\hline Total Resource Conservation and Recovery Act Metals ${ }^{c}$ & --- & $\mathrm{X}$ \\
\hline Total Beryllium ${ }^{c}$ & --- & $\mathrm{X}$ \\
\hline \multicolumn{3}{|c|}{ Radionuclide COPCs } \\
\hline Gamma Emitters & $\mathrm{X}$ & $X$ \\
\hline Isotopic Uranium & $\mathrm{X}$ & $x$ \\
\hline Isotopic Plutonium & $x$ & $x$ \\
\hline Strontium-90 & $x$ & $X$ \\
\hline
\end{tabular}

${ }^{a}$ The contaminants of potential concern are the analytes reported from the analytical methods listed.

${ }^{b}$ If the volume of material is limited, prioritization of the analyses will be necessary.

'May also include Toxicity Characteristic Leaching Procedure analytes if sample is collected for waste management purposes.

$X$ - Required analytical method

$---=$ Analyses will not be performed at this feature.

COPC $=$ Contaminant of potential concern

chemical or radionuclide parameter that can be detected in a sample within an acceptable level of error. Due to changes in analytical methodology and changes in analytical laboratory contracts, information in Tables 7-2 and 7-3 that varies from corresponding information in the Industrial Sites Quality Assurance Project Plan (QAPP) will supersede that information in the QAPP (NNSA/NV, 2002). 


\subsection{Results of the DQO Analysis}

\subsubsection{Action Level Determination and Basis}

The PALs presented in this section are to be used for site screening purposes. They are not necessarily intended to be used as cleanup action levels or FALs. However, they are useful in screening out contaminants that are not present in sufficient concentrations to warrant further evaluation, therefore streamlining the consideration of remedial alternatives. The RBCA process used to establish FALs is described in the Industrial Sites Project Establishment of Final Action Levels (NNSA/NSO, 2006). This process conforms with Nevada Administrative Code (NAC) Section 445A.227, which lists the requirements for sites with soil contamination (NAC, 2005). For the evaluation of corrective actions, NAC Section 445A.22705 requires the use of American Society for Testing and Materials (ASTM) Method E1739-95 to “conduct an evaluation of the site, based on the risk it poses to public health and the environment, to determine the necessary remediation standards (i.e., FALs) or to establish that corrective action is not necessary” (ASTM, 1995).

This RBCA process, summarized in Figure 3-1, defines three tiers (or levels) of evaluation involving increasingly sophisticated analyses:

- Tier 1 evaluation - sample results from source areas (highest concentrations) are compared to action levels based on generic (non-site-specific) conditions (i.e., the PALs established in the SAFER). The FALs may then be established as the Tier 1 action levels, or the FALs may be calculated using a Tier 2 evaluation.

- $\quad$ Tier 2 evaluation - conducted by calculating Tier 2 site-specific target levels (SSTLs) using site-specific information as inputs to the same or similar methodology used to calculate Tier 1 action levels. The Tier 2 SSTLs are then compared to individual sample results from reasonable points of exposure (as opposed to the source areas as is done in Tier 1) on a point-by-point basis. Total TPH concentrations will not be used for risk-based decisions under Tier 2 or Tier 3. Rather, the individual chemicals of concern will be compared to the SSTLs.

- Tier 3 evaluation - conducted by calculating Tier 3 SSTLs on the basis of more sophisticated risk analyses using methodologies described in Method E1739-95 that consider site-, pathway-, and receptor-specific parameters.

This process includes a provision for conducting an interim remedial action if necessary and appropriate. The decision to conduct an interim action may be made at any time during the 


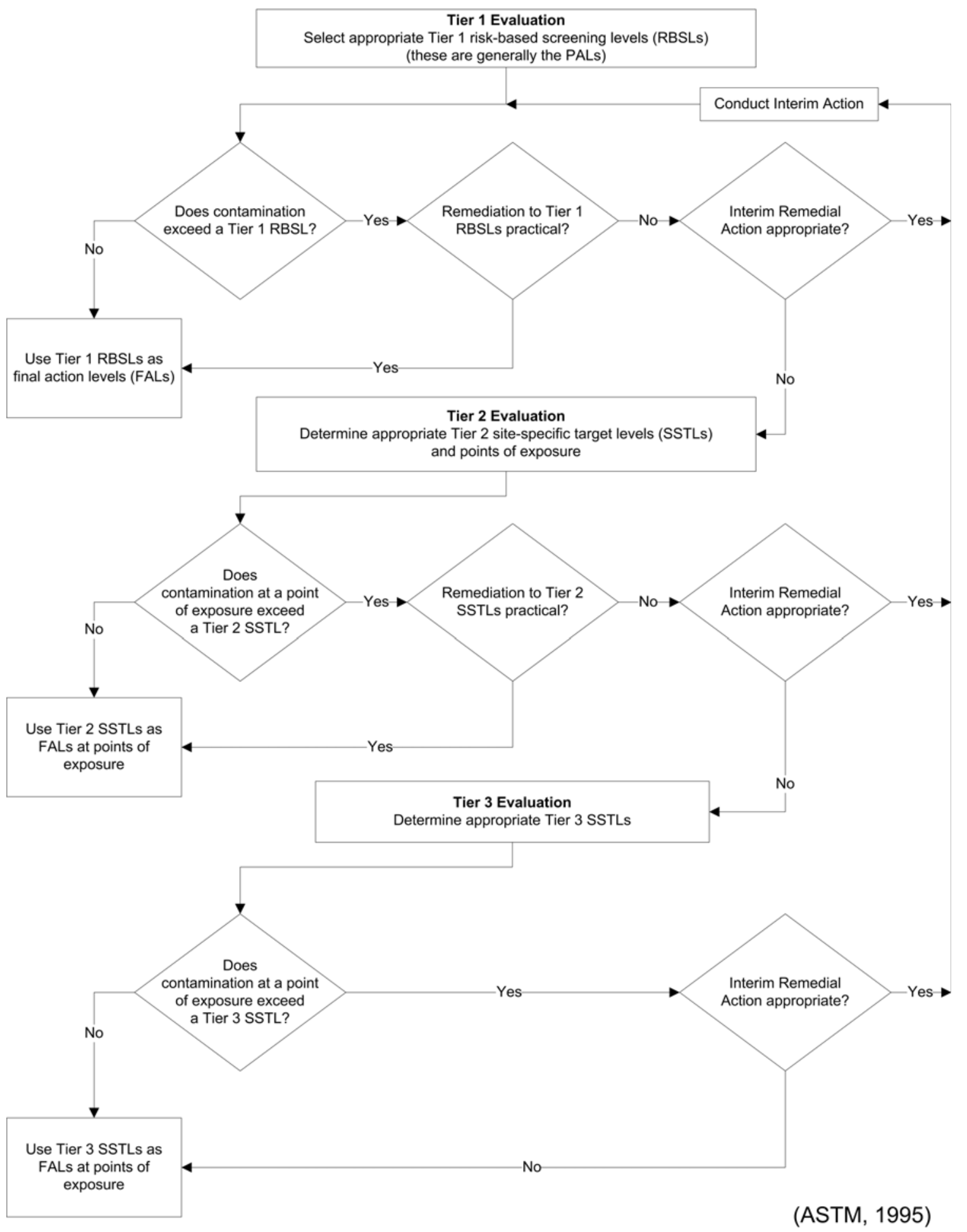

Figure 3-1

Risk-Based Corrective Action Decision Process 
investigation and at any level (tier) of analysis. Concurrence of the decision-makers listed in Section B.2.1 will be obtained before any interim action is implemented. Evaluation of DQO decisions will be based on conditions at the site following completion of any interim actions. Any interim actions conducted will be reported in the investigation report. The FALs (along with the basis for their selection) will be proposed in the investigation report, where they will be compared to laboratory results in the evaluation of potential corrective actions.

\subsubsection{Chemical PALs}

Except as noted herein, the chemical PALs are defined as the U.S. Environmental Protection Agency (EPA) Region 9 Risk-Based Preliminary Remediation Goals (PRGs) for chemical contaminants in industrial soils (EPA, 2004). Background concentrations for RCRA metals will be used instead of PRGs when natural background concentrations exceed the PRG, as is often the case with arsenic on the NTS. Background is considered the mean plus two standard deviations of the mean for sediment samples collected by the Nevada Bureau of Mines and Geology throughout the Nevada Test and Training Range (formerly the Nellis Air Force Range) (NBMG, 1998; Moore, 1999). For detected chemical COPCs without established PRGs, the protocol used by the EPA Region 9 in establishing PRGs (or similar) will be used to establish PALs. If used, this process will be documented in the Closure Report.

\subsubsection{Total Petroleum Hydrocarbon PALs}

The PAL for TPH is 100 parts per million (ppm) as listed in NAC 445A.2272 (NAC, 2005).

\subsubsection{Radionuclide PALs}

The PALs for radiological contaminants (other than tritium) are based on (a) the National Council on Radiation Protection and Measurement Report No. 129 recommended screening limits for construction, commercial, industrial land-use scenarios (NCRP, 1999) using 25 millirem per year dose constraint (Murphy, 2004) and the generic guidelines for residual concentration of radionuclides in DOE Order 5400.5 (DOE, 1993). These PALs are based on the construction, commercial, and industrial land-use scenario provided in the guidance and are appropriate for the NTS based on the future land uses presented in Section B.2.2.6. The radiological PALs for CAU 177 are listed in Table 7-2. 
Solid media such as concrete and/or structures may pose a potential radiological exposure risk to site workers if contaminated. The radiological PAL for solid media will be defined as the unrestricted-release criteria defined in the NV/YMP RadCon Manual (NNSA/NSO, 2004b).

\subsubsection{Hypothesis Test}

The null hypothesis is that closure objectives have not been met. Sufficient evidence to prove the null hypothesis wrong is:

- the identification of the lateral and vertical extent of COC contamination in media, if present

- sufficient information to properly dispose of IDW and remediation waste.

\subsubsection{Statistical Model}

A judgmental sampling design will be implemented to select sample locations and evaluate DQO decisions for all cellars (CASs 08-23-01, 09-09-45, 09-23-05, 09-23-08, 09-23-09, 10-23-02, 10-23-03, 19-23-01, 19-23-02, 19-23-03, and 20-23-07). A judgmental sampling approach will be implemented for mud pits if unexpected biasing factors are identified.

A probabilistic sampling scheme will be implemented to select sample locations and evaluate DQO decisions for all mud pits (CASs 08-23-01, 09-09-45, 09-23-05, 09-23-08, 10-23-02, 10-23-03, 19-23-01). Both sampling designs will assume that the data are not normally distributed and that the statistical test will be to compare results to a fixed threshold (FALs).

\subsubsection{Design Description/Option}

\subsubsection{Judgmental Sampling}

Because individual sample results, rather than an average concentration, will be used to compare to FALs at the CASs undergoing judgmental sampling, statistical methods to generate site characteristics will not be used. Section 0.4.4 of the EPA Data Quality Objectives Process for Hazardous Waste Site Investigations (EPA, 2002) guidance states that the use of statistical methods may not be warranted by program guidelines or site-specific sampling objectives. The need for statistical methods is dependent upon the decisions being made. Section 7.1 of the EPA QA/G-4HW guidance states that a nonprobabilistic (judgmental) sampling design is developed when there is 
sufficient information on the contamination sources and history to develop a valid CSM and to select specific sampling locations. This design is used to confirm the existence of contamination at specific locations and provide information (such as extent of contamination) about specific areas of the site.

All sample locations will be selected to satisfy the DQI of representativeness in that samples collected from selected locations will best represent the populations of interest as defined in Section B.8.2. To meet this criterion for judgmentally sampled sites, a biased sampling strategy will be used for Decision I samples to target areas with the highest potential for contamination, if it is present anywhere in the CAS. Sample locations will be determined based on process knowledge, previously acquired data, or the field-screening and biasing factors listed in Section 4.2. If biasing factors are present in soils below locations where Decision I samples were removed, additional Decision I soil samples will be collected at depth intervals selected by the Site Supervisor (SS) based on biasing factors to a depth where the biasing factors are no longer present. The SS has the discretion to modify the judgmental sample locations, but only if the modified locations meet the decision needs and criteria stipulated in this DQO.

\subsubsection{Probabilistic Sampling}

For probabilistically sampled mud pits, randomly selected sample locations will be chosen, with locations specified by the Visual Sample Plan (VSP) software (PNNL, 2005). If a location contains a shallow, hard object (e.g., rock, caliche or buried concrete) the SS will establish the location at the nearest place that a surface sample can be obtained. The information provided from probabilistic sampling allows for establishing contaminant concentrations that represent the site as a whole.

\subsubsection{Conceptual Site Model and Drawing}

The CSM describes the most probable scenario for current conditions at each site and defines the assumptions that are the basis for identifying the future land use, contaminant sources, release mechanisms, migration pathways, exposure points, and exposure routes. The CSM is also used to support appropriate sampling strategies and data collection methods. A single CSM was developed for CAU 177 using information from the physical setting, potential contaminant sources, release information, process knowledge, information from similar sites, and physical and chemical properties of the potentially affected media and COPCs. Figure 3-2 depicts a flow diagram of the CSM that 
illustrates the complete, potential, and incomplete pathways for transporting contaminants to receptors. The dominant pathway is exposure of NTS workers or visitors to contaminated residual mud or surface soils through inhalation, ingestion, or dermal contact. The primary release mechanism is the direct release of drilling mud to mud pits, or drill rig fluids and decontamination rinsate to cellars. Surface water is not expected to be impacted by a release as there are no nearby drainages at any CASs. Subsurface media is not expected to be impacted and would only be a pathway if it were excavated. Contaminants are also not expected to reach regional aquifers because leaching of contaminants through soil is limited. Figure 3-3 depicts a graphical representation of the CSM. A detailed discussion of the elements of the CSM can be found in Section B.2.2 and Table B.2-2. 


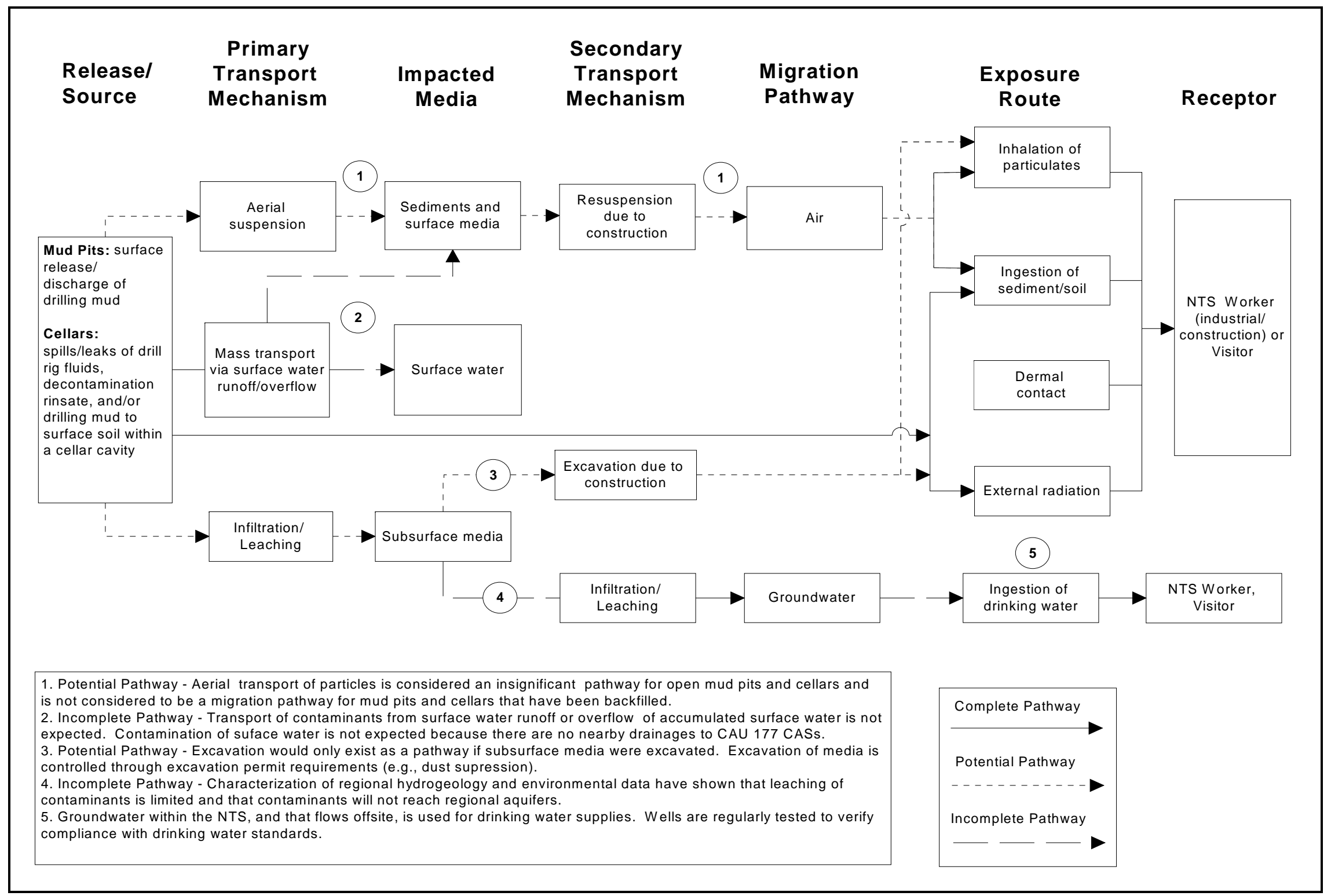

Figure 3-2 


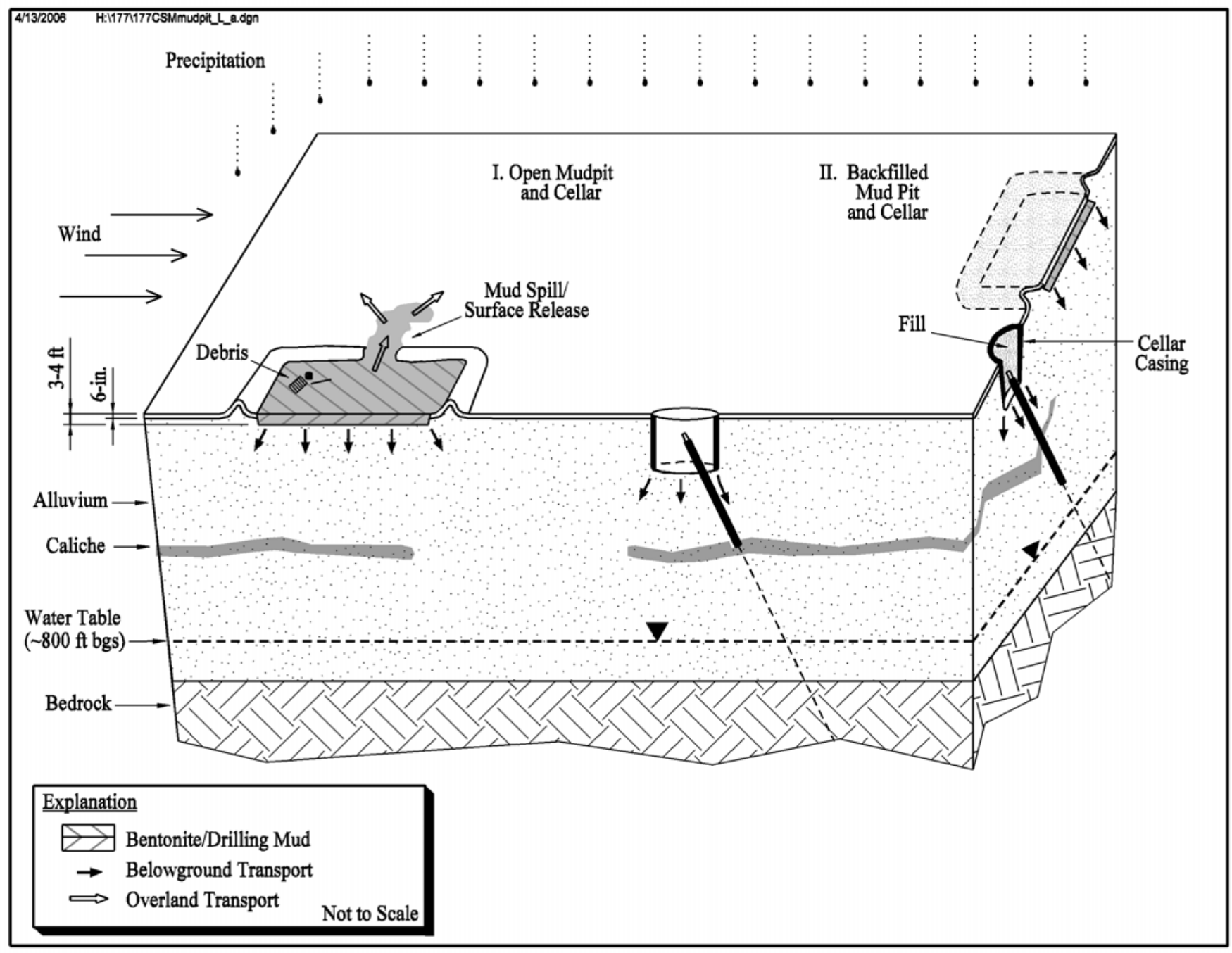

Figure 3-3

Conceptual Site Model Diagram for CAU 177 


\subsection{Field Activities and Closure Objectives}

This section of the SAFER Plan provides a description of the field activities and closure objectives for CAU 177. The objectives for the field activities are to determine whether COCs exist and, if so, define the extent so that closure alternatives may be implemented. For CASs that consist of a mud pit and cellar, the closure objective is to close the mud pits and cellars independent of one another utilizing the NFA alternative with a contingency for closure in place with appropriate administrative controls. The rationale for the field activities and sampling approaches presented in this section are based on the CSM. All sampling activities will be conducted in compliance with the Industrial Sites QAPP (NNSA/NV, 2002) and other applicable, approved procedures and instructions.

\subsection{Contaminants of Potential Concern}

The COPCs applicable to Decision I environmental samples from each mud pit and cellar of CAU 177 are defined as the analytes reported from the analyses stipulated in Table 3-1. The list of COPCs is intended to encompass contaminants that are potentially present at each CAS. These contaminants were identified during the planning process through the review of site history, process knowledge, personal interviews, past investigation efforts (where available), and inferred activities associated with the CASs. As a result of this review, it was decided that only radiological contaminants are expected to be present at CAU 177 mud pits, as shown in Table 3-1. Because complete information regarding activities performed at the CAU 177 cellars is not available, a broad suite of COPCs was included in the contaminant lists to reduce the uncertainty (Table B.4-2).

During the review of previous information and investigations, some of the COPCs were identified as targeted analytes at specific CASs. Targeted analytes are those COPCs for which evidence in the available site and process information suggests that they may be reasonably suspected to be present at a given CAS. The targeted analytes are required to meet a more stringent completeness criteria than other COPCs, thus providing greater protection against a decision error (see Section 7.2.1). For this investigation, Eu-152 and Pu-239 have been identified as targeted analytes for all CASs (Table 4-1) based on preliminary sampling results from a previous investigation of CAS 09-09-41 and 09-09-45 (SNJV, Date Unknown). 
Table 4-1

Targeted Analytes for All CAU 177 CASs

\begin{tabular}{|c|c|c|}
\hline Feature & Chemical Targeted Analyte(s) & Radiological Targeted Analyte(s) $^{\mathrm{a}}$ \\
\hline \hline Mud Pit & None & Europium-152, Plutonium-239 \\
\hline Cellar & None & Europium-152, Plutonium-239 \\
\hline
\end{tabular}

${ }^{a}$ The evidence for radiological target analytes at mud pits and cellars is from previous sampling results of CAS 09-09-41 and CAS 09-09-45. See Sections 2.3.3 and 2.4.3.

Source: SNJV, Date Unknown

\subsection{Remediation}

The DQOs developed for CAU 177 identified data gaps that require additional data collection before identifying and implementing the preferred closure alternative for each CAS. A decision point approach, based on the DQOs, has been chosen to address the data collection activities. The presence of contamination, if any, is assumed to be confined to the spatial boundaries of the sites as defined in the DQO process and CSM. According to DQO guidelines (Appendix B), probabilistic sampling will be conducted at all mud pits, and judgmental sampling will be conducted at all cellars and at mud pits where unexpected biasing factors are identified.

If COCs are identified within a CAS based on the initial investigation results, that CAS will be further assessed before implementing closure activities. If COPCs are not present at concentrations exceeding FALs, the CAS will be recommended for NFA. The objective of the initial investigation strategy is to determine whether COCs are present. Laboratory analytical results will be used to confirm the presence or absence of COCs.

The judgmental and probabilistic sampling strategies are presented in Appendix B. Predetermined biased sample locations may be justified by the SS, based on the criteria for satisfying DQO data needs listed in Appendix B. Additional samples may be collected for waste management characterization and disposal purposes. 


\subsubsection{Field Activities}

Field activities at each CAS will consist of collecting and analyzing samples at mud pits and cellars to generate the information necessary to satisfy the DQO data needs (Appendix B). Samples collected at mud pits will be located systematically throughout each pit based on a triangular grid pattern. This ensures the probabilistic sampling approach will yield radiological concentrations that are considered to be characteristic of the mud pit. All samples will be surface samples of the residual mud (0 to 12 in. bgs). For those mud pits that have been backfilled, sample collection will involve digging through the cover material to obtain a sample that extends from the cover/residual mud interface to 12 in. below the interface. If the interface between the cover material and mud is not recognizable, then a subsurface sample will be collected at the depth where mud is expected to be located based on the dimensions of similar NTS mud pits. Field screening may also be used to select subsurface sample locations, where a mud horizon is not recognizable. Additional biased samples may be collected in areas of obvious debris, spills, or soil staining, located within or adjacent to the mud pit. Figure B.8-1 shows an example of a predetermined layout of surface sample locations to be collected at mud pits. Refer to Figures C.1-1 through C.1-10 for the actual VSP generated sample locations at each mud pit.

Samples collected at cellars will be from surface soil ( 0 to 12 in.) at the base of open cellars. For backfilled cellars, sample collection will involve excavation or drilling through the cover material to obtain a sample from the first 12 in. of soil directly below the cover material. If the interface between the cover material and impacted soil is not recognizable, then a subsurface sample will be collected at the depth where the cellar bottom is expected to be located based on the dimensions of similar open cellars. Access restrictions related to the presence of drill stemming in the cellar cavity will be considered for selecting sample locations (see Figure B.8-2).

The SS has the discretion to modify sample locations or decide whether additional samples are needed but only if the modified locations meet the decision needs and criteria stipulated in the DQOs (Appendix B). Modifications to the investigative strategy may be required should unexpected field conditions be encountered at any CAS. Significant modifications shall be justified and documented on a Record of Technical Change (ROTC) before implementation. If an unexpected condition indicates that conditions are significantly different than the corresponding CSM, the activity will be rescoped and the identified decision-makers will be notified. 


\subsubsection{Site Preparation Activities}

Before collecting soil samples as part of the field investigation, the following site preparation activities must be completed:

- Construction of temporary site exclusion zones

- Removal of fencing (including T-posts) at applicable CASs for heavy equipment access

- Removal of dirt mounds, if present, covering backfilled mud pits or cellars if it hinders sample collection methods

- Removal of easily managed, non-hazardous, and non-radioactive debris, including vegetation, (e.g., tumbleweeds). For open mud pits and cellars, vegetation will be removed only if it hinders access to the predetermined sample locations or obscures the visual surveys. For backfilled features, vegetation will be removed from just the locations to be sampled

- Visual surveys at each mud pit and cellar that is to be sampled to identify any staining, discoloration, or any other indication of potential contamination

- Radiological surveys at the sample locations within each mud pit and cellar for health and safety purposes

\subsection{Verification}

The information necessary to satisfy the closure criteria will be generated for each mud pit and cellar by collecting and analyzing samples generated during a field investigation. If a COC is present and removal of the COC is feasible, verification sampling of remaining environmental media will be required. The verification samples will be collected from the approximate center of the bottom of the excavation below the stained area and at lateral boundaries. The final locations and numbers of verification samples to be collected will be determined in the field based on the presence of any biasing factors as listed in Section B.4.2.1.1 of Appendix B, the size of the excavation, site conditions, and the professional judgment of the SS. All verification sample locations must meet the DQO decision needs and criteria stipulated in Appendix B. The number and location of verification samples will be justified in the Closure Report.

For a cellar, if a COC is present and removal of the COC is not feasible, information on the extent of COC contamination will be obtained by collecting step-out (Decision II) samples. Decision II 
sampling will consist of further defining the extent of contamination where COCs have been confirmed. Step-out (Decision II) sampling locations at each CAS will be selected based on the CSM, biasing factors, field-screening results (FSRs), existing data, and the outer boundary sample locations where COCs were detected. In general, step-out sample locations will be arranged in a triangular pattern around areas containing a COC at distances based on site conditions, COC concentrations, process knowledge, and other biasing factors. If COCs extend beyond step-out locations, additional Decision II samples will be collected from locations further from the source. If a spatial boundary is reached, the CSM is shown to be inadequate, or the SS determines that extent sampling needs to be re-evaluated, work will be temporarily suspended, NDEP will be notified, and the investigation strategy will be re-evaluated. Decision II sampling is not required for mud pits because of the probabilistic sampling planned and the assumption that contaminants, if present, are bound within the matrix of the residual drilling mud; therefore, the extent of contamination would be defined as the structural boundaries of the mud pit.

The closure objectives will have been met and the CAS will be proposed for closure if the following conditions are true:

- A COC is not present at a CAS, or a COC is present and the extent of each COC has been defined.

- Information is sufficient to characterize remediation waste and IDW for disposal.

Because this SAFER Plan only addresses contamination originating from the CAU, it may be necessary to distinguish overlapping contamination originating from other sources. For example, widespread surface radiological contamination originating from atmospheric tests will not be addressed in the CAU 177 investigation. To determine whether contamination is from the CAU or from other sources, soil samples may be collected from background locations at selected CASs; however, this is not expected for CAU 177.

Modifications to the investigative strategy may be required should unexpected field conditions be encountered at any CAS. Significant modifications shall be justified and documented on an ROTC before implementation. If an unexpected condition indicates that conditions are significantly different than the corresponding CSM, the activity will be rescoped and the identified decision-makers will be notified. 


\subsection{Closure}

The following activities, at a minimum, have been identified for closure of the CAU 177 mud pits and cellars. The decision logic behind the activities is provided in Figure 1-2:

- If no COCs are present, the mud pit or cellar will be closed with NFA.

- If a COC is present, the extent of COC contamination will be determined and closure in place will be implemented and documented in the SAFER Closure Report.

Following completion of the SAFER investigation and waste management activities, the following actions will be implemented before closure of the site Real Estate/Operations Permit:

- All equipment, wastes, debris, and materials associated with the investigation will be removed.

- Site will be graded to pre-investigation condition (unless changed condition is necessary under a corrective action).

- Site will be inspected and certified that restoration activities have been completed.

\subsection{Duration}

The following is a tentative duration of activities (in work days) for SAFER activities:

Table 4-2

CAU 177 SAFER Project Duration

\begin{tabular}{|c|c|}
\hline Duration (days) & Activity \\
\hline \hline 10 & Site Preparation \\
\hline 76 & Field Work Preparation and Mobilization \\
\hline 20 & Sampling \\
\hline 160 & Data Assessment \\
\hline 180 & Waste Management \\
\hline
\end{tabular}




\subsection{Reports and Records Availability}

Historic information and documents referenced in this plan are retained in the NNSA/NSO project files in Las Vegas, Nevada, and can be obtained through written request to the NNSA/NSO Federal Sub-Project Director. This document is available in the DOE public reading rooms located in Las Vegas and Carson City, Nevada, or by contacting the appropriate DOE Project Manager. The NDEP maintains the official Administrative Record for all activities conducted under the auspices of the FFACO. 


\subsection{Investigation/Remediation Waste Management}

Management of IDW and remediation waste will be based on regulatory requirements, field observations, process knowledge, and laboratory results from CAU 177 investigation samples.

Disposable sampling equipment, personal protective equipment (PPE), and rinsate are considered potentially contaminated waste only by virtue of contact with potentially contaminated media (e.g., soil) or potentially contaminated debris (e.g., construction materials). Therefore, sampling and analysis of IDW, separate from analyses of site investigation samples, may not be necessary for all IDW. However, if associated investigation samples are found to contain contaminants above regulatory levels, conservative estimates of total waste contaminant concentrations may be made based on the mass of the waste, the amount of contaminated media contained in the waste, and the maximum concentration of contamination found in the media. Direct samples of IDW may also be taken to support waste characterization.

Sanitary, hazardous, radioactive, and/or mixed waste, if generated, will be managed and disposed of in accordance with DOE Orders, U.S. Department of Transportation (DOT) regulations, state and federal waste regulations, and agreements and permits between DOE and NDEP.

\subsection{Waste Minimization}

Investigation activities are planned to minimize IDW generation. This will be accomplished by incorporating the use of process knowledge, visual examination, and/or radiological survey and swipe results. When possible, disturbed media (such as soil removed during trenching) or debris will be returned to its original location. Contained media (e.g., soil managed as waste) as well as other IDW will be segregated to the greatest extent possible to minimize generation of hazardous, radioactive, or mixed waste. Hazardous material used at the sites will be controlled in order to limit unnecessary generation of hazardous or mixed waste. Administrative controls, including decontamination procedures and waste characterization strategies, will minimize waste generated during investigations. 


\subsection{Potential Waste Streams}

Waste generated during the corrective action activities will include the following potential waste streams:

- Personal protective equipment and disposable sampling equipment (e.g., plastic, paper, sample containers, aluminum foil, spoons, bowls)

- Decontamination rinsate

- Environmental media (e.g., soil)

- Surface debris in investigation area (e.g., lead brick)

- Field-screening waste (e.g., spent solvent, disposable sampling equipment, and/or PPE contaminated by field-screening activities)

The on-site management and ultimate disposition of wastes will be determined based on a determination of the waste type (e.g., sanitary, low-level, hazardous, hydrocarbon, mixed), or the combination of waste types. A determination of the waste type will be guided by several factors, including, but not limited to: the analytical results of samples directly or indirectly associated with the waste, historical site knowledge, knowledge of the waste generation process, field observations, field-monitoring/screening results, and/or radiological survey/swipe results.

Table 4-2 of the NV/YMP RadCon Manual (NNSA/NSO, 2004b) shall be used to determine whether such materials may be declared nonradioactive. On-site IDW management requirements by waste type are detailed in the following sections. Applicable waste management regulations and requirements are listed in Table 6-1.

\subsubsection{Sanitary Waste}

Sanitary IDW generated at each CAS will be collected, managed, and disposed of in accordance with the sanitary waste management regulations and the permits for operation of the NTS 10c Industrial Waste Landfill.

Office trash and lunch waste will be placed in the dumpster to be transported to the sanitary landfill for disposal. Sanitary IDW generated at each CAS will only be collected in plastic bags, sealed, 
Table 6-1

Waste Management Regulations and Requirements

\begin{tabular}{|c|c|c|}
\hline Waste Type & Federal Regulation & Additional Requirements \\
\hline Solid (nonhazardous) & N/A & $\begin{array}{c}\text { NRS }^{\mathrm{a}} 444.440-444.620 \\
\text { NAC }^{\mathrm{b}} 444.570-444.7499 \\
\text { NTS Landfill Permit SW13.097.04 } \\
\text { NTS Landfill Permit SW13.097.03 }\end{array}$ \\
\hline Liquid/Rinsate (nonhazardous) & N/A & $\begin{array}{l}\text { Water Pollution Control General Permit } \\
\text { GNEV93001, Rev. 3iii }\end{array}$ \\
\hline Hazardous & $\begin{array}{c}\text { RCRA }^{f} \\
40 \text { CFR 260-282 }\end{array}$ & $\begin{array}{c}\text { NRS }^{\mathrm{a}} 459.400-459.600 \\
\text { NAC }^{\mathrm{b}} 444.850-444.8746 \\
\text { POC }^{\mathrm{g}}\end{array}$ \\
\hline Low-Level Radioactive & N/A & DOE Orders and NTSWAC ${ }^{h}$ \\
\hline Mixed & $\begin{array}{c}\text { RCRA }^{f} \\
40 \text { CFR 260-282 }\end{array}$ & $\begin{array}{l}\text { NTSWAC } \\
\text { POC }^{\mathrm{h}}\end{array}$ \\
\hline Hydrocarbon & N/A & NTS Landfill Permit SW13.097.02 \\
\hline Polychlorinated Biphenyls & $\begin{array}{l}\text { TSCA }^{\mathrm{j}} \\
40 \text { CFR } 761\end{array}$ & $\begin{array}{l}N_{R S}^{a} 459.400-459.600 \\
\text { NAC }^{b} 444.940-444.9555\end{array}$ \\
\hline Asbestos & $\begin{array}{c}\text { TSCA }^{\mathrm{j}} \\
40 \text { CFR } 763\end{array}$ & $\begin{array}{l}\text { NRS }^{a} 618.750-618.840 \\
\text { NAC }^{b} 444.965-444.976\end{array}$ \\
\hline
\end{tabular}

${ }^{a}$ Nevada Revised Statutes (NRS, 2005a, b, c)

${ }^{\mathrm{b}}$ Nevada Administrative Code (NAC, 2004a, b, c, d)

${ }^{\mathrm{c} A r e a} 23$ Class II Solid Waste Disposal Site (NDEP, 1997a)

${ }^{\text {dA Area }} 9$ Class III Solid Waste Disposal Site (NDEP, 1997c)

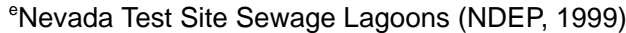

${ }^{\mathrm{f}}$ Resource Conservation and Recovery Act (CFR, 2005a)

${ }^{9}$ Nevada Test Site Performance Objective for the Certification of Nonradioactive Hazardous Waste (BN, 1995)

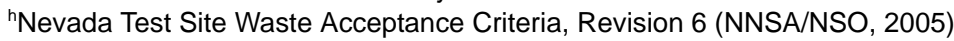

'Area 6 Class III Solid Waste Disposal Site for hydrocarbon waste (NDEP, 1997b)

'Toxic Substance Control Act (CFR, 2005b, c)

CFR $=$ Code of Federal Regulations

DOE $=$ U.S. Department of Energy

N/A = Not applicable

NAC $=$ Nevada Administrative Code

NDEP $=$ Nevada Division of Environmental Protection

NRS = Nevada Revised Statutes

NTS $=$ Nevada Test Site

NTSWAC = Nevada Test Site Waste Acceptance Criteria

$\mathrm{POC}=$ Performance Objective for the Certification of Nonradioactive Hazardous Waste

RCRA = Resource Conservation and Recovery Act

TSCA = Toxic Substance Control Act 
labeled with the CAS number from each site in which it was generated, and dated. The waste will then be placed in a roll-off box located in Mercury or other approved roll-off box location. The number of bags of sanitary IDW placed in the roll-off box will be counted as they are placed in the roll-off box, noted in a log, and documented in the Field Activity Daily Log. These logs will provide necessary tracking information for ultimate disposal in the 10c Industrial Waste Landfill.

\subsubsection{Low-Level Radioactive Waste}

Radiological swipe surveys and/or direct-scan surveys shall be conducted on reusable sampling equipment, PPE, decontamination liners, and disposable sampling equipment waste streams exiting a radiologically controlled area. This allows for the immediate segregation of radioactive waste from waste that may be unrestricted regarding radiological release. Removable contamination limits, as defined in Table 4-2 of the current version of the NV/YMP RadCon Manual (NNSA/NSO, 2004b), will be used to determine whether such waste may be declared unrestricted regarding radiological release versus being declared radioactive waste. Direct sampling of the waste may be conducted to aid in determining whether a particular waste unit (e.g., drum of soil) contains low-level radioactive waste, as necessary. Waste that is determined to be below the values of Table 4-2, by direct radiological survey/swipe results or through process knowledge, will not be managed as potential radioactive waste but will be managed in accordance with the appropriate section of this document. Wastes in excess of Table 4-2 values will be managed as potential radioactive waste and be managed in accordance with this section and any other applicable sections of this document.

Low-level radioactive waste, if generated, will be managed in accordance with the contractor-specific waste certification program plan, DOE Orders, and the requirements of the current version of the Nevada Test Site Waste Acceptance Criteria (NTSWAC) (NNSA/NV, 2005a). Potential radioactive waste drums containing soil, PPE, disposable sampling equipment, and/or rinsate may be staged at a designated RMA or radiologically controlled area when full or at the end of an investigation phase. The waste drums will remain at the designated RMA pending certification and disposal under NTSWAC requirements (NNSA/NV, 2005a). 


\subsubsection{Hazardous Waste}

Suspected hazardous waste will be placed in DOT-compliant containers. All containerized hazardous waste will be handled, inspected, and managed in accordance with Title 40 Code of Federal Regulations (CFR) 265, Subpart I (CFR, 2005a). This provision includes managing the waste in containers compatible with the waste type, and segregating incompatible waste types so that in the event of a spill, leak, or release, incompatible wastes shall not contact one another. Corrective Action Unit 177 will have waste storage areas established according to the needs of the project. Satellite accumulation areas (SAAs) and hazardous waste accumulation areas (HWAAs) will be managed consistent with the requirements of Federal and State regulations (CFR, 2005a; NAC, 2004b). They will be properly controlled for access and equipped with spill kits and appropriate spill containment.

The HWAAs will be covered under a site-specific emergency response and contingency action plan until such time that the waste is determined to be nonhazardous or all containers of hazardous waste have been removed from the storage area. Hazardous wastes will be characterized in accordance with the requirements of Title 40 CFR 261 (CFR, 2005a). No RCRA "listed” wastes have yet been identified at CAU 177. Any waste determined to be hazardous will be transported in accordance with RCRA and DOT to a permitted treatment, storage, and disposal facility (CFR, 2005a).

\subsubsection{Hydrocarbon Waste}

Hydrocarbon waste containing more than 100 milligrams per kilogram $(\mathrm{mg} / \mathrm{kg})$ of TPH will be managed on site in a drum or other appropriate container until fully characterized. Hydrocarbon waste may be disposed of at a designated hydrocarbon landfill (NDEP, 1997b), an appropriate hydrocarbon waste management facility (e.g., recycling facility), or other method in accordance with Nevada regulations.

\subsubsection{Mixed Low-Level Waste}

Mixed waste, if generated, shall be managed and dispositioned according to the requirements of RCRA (CFR, 2005a) or subject to agreements between NNSA/NSO and the State of Nevada, as well as DOE requirements for radioactive waste. The waste will be marked with the words "Hazardous Waste Pending Analysis and Radioactive Waste Pending Analysis.” Waste characterized as mixed will not be stored for a period of time that exceeds the requirements of RCRA unless subject to 
agreements between NNSA/NSO and the State of Nevada. The mixed waste shall be transported via an approved hazardous waste/radioactive waste transporter to the NTS transuranic waste storage pad for storage pending treatment or disposal. Mixed waste with hazardous waste constituent concentrations below Land Disposal Restrictions may be disposed of at the NTS Area 5 Radioactive Waste Management Site if the waste meets the requirements of the NTSWAC (NNSA/NSO, 2005). Mixed waste constituent concentrations exceeding Land Disposal Restrictions will require development of a treatment and disposal plan under the requirements of the Mutual Consent Agreement between DOE and the State of Nevada (NDEP, 1995).

\subsubsection{Polychlorinated Biphenyls}

The management of polychlorinated biphenyls (PCBs) is governed by the Toxic Substances Control Act (TSCA) (USC, 1976) and its implementing regulations at 40 CFR 761 (CFR, 2005b). Polychlorinated biphenyls contamination may be found as a sole contaminant or in combination with any of the types of waste discussed in this document. For example, PCBs may be a co-contaminant in soil that contains a RCRA “characteristic” waste (PCB/hazardous waste), or in soil that contains radioactive wastes ( $\mathrm{PCB} /$ radioactive waste), or even in mixed waste ( $\mathrm{PCB} /$ radioactive/hazardous waste). The IDW will initially be evaluated using analytical results for media samples from the investigation. If any type of PCB waste is generated, it will be managed according to 40 CFR 761 (CFR, 2005b) as well as State of Nevada requirements (NAC, 2004c), guidance, and agreements with NNSA/NSO. 


\subsection{Quality Assurance/Quality Control}

The overall objective of the characterization activities described in this SAFER Plan is to collect accurate and defensible data to support the selection and implementation of a closure alternative for each CAS in CAU 177. Sections 7.1 and 7.2 discuss the collection of required quality control (QC) samples in the field and quality assurance (QA) requirements for laboratory/analytical data to achieve closure. Unless otherwise stated in this SAFER Plan or required by the results of the DQO process (see Appendix B), this investigation will adhere to the Industrial Sites QAPP (NNSA/NV, 2002).

\subsection{Sample Collection Activities}

Field QC samples will be collected in accordance with established procedures. Field QC samples are collected and analyzed to aid in determining the validity of environmental sample results. The number of required QC samples depends on the types and number of environmental samples collected. The minimum frequency of collecting and analyzing QC samples for this investigation, as determined in the DQO process, include:

- Trip blanks (1 per sample cooler containing volatile organic compound [VOC] environmental samples)

- Equipment rinsate blanks (1 per sampling event for each type of decontamination procedure)

- $\quad$ Source blanks (1 per lot of source material that contacts sampled media)

- Field duplicates (1 per 20 environmental samples or 1 per CAS per matrix, if less than 20 collected)

- Field blanks (1 per 20 environmental samples or 1 per day)

- Laboratory QC samples (1 per 20 environmental samples or 1 per CAS per matrix, if less than 20 collected)

Additional QC samples may be submitted based on site conditions at the discretion of the Task Manager or SS. Field QC samples shall be analyzed using the same analytical procedures implemented for associated environmental samples. Additional details regarding field QC samples are available in the Industrial Sites QAPP (NNSA/NV, 2002). 


\subsection{Applicable Laboratory/Analytical Data Quality Indicators}

The DQIs are qualitative and quantitative descriptors used in interpreting the degree of acceptability or utility of data. Data quality indicators are used to evaluate the entire measurement system and laboratory measurement processes (i.e., analytical method performance) as well as to evaluate individual analytical results (i.e., parameter performance). The quality and usability of data used to make DQO decisions will be assessed based on the following DQIs:

- Precision

- Accuracy/bias

- Representativeness

- Comparability

- Completeness

- Sensitivity

Table 7-1 provides the established analytical method/measurement system performance criteria for each of the DQIs and the potential impacts to the decision if the criteria are not met. The following subsections discuss each of the DQIs that will be used to assess the quality of laboratory data. Due to changes in analytical methodology and changes in analytical laboratory contracts, criteria for precision and accuracy in Tables 7-2 and 7-3 that vary from corresponding information in the Industrial Sites QAPP will supersede that information in the Industrial Sites QAPP (NNSA/NV, 2002).

\subsubsection{Precision}

Precision is a measure of the repeatability of the analysis process from sample collection through analysis results. Determinations of precision will be made for laboratory duplicate samples. The laboratory sample duplicates are an aliquot, or subset, of a field sample generated in the laboratory. They are not a separate sample but a split, or portion, of an existing sample. Typically, laboratory duplicate QC samples may include matrix spike duplicate and laboratory control sample (LCS) duplicate samples for organic, inorganic, and radiological analyses.

Precision is a quantitative measure used to assess overall analytical method and field sampling performance as well as to assess the need to "flag" (qualify) individual parameter results when corresponding QC sample results are not within established control limits. The criteria used for the 
Table 7-1

Data Quality Indicator Performance Metrics

\begin{tabular}{|c|c|c|}
\hline $\begin{array}{l}\text { Data Quality } \\
\text { Indicator }\end{array}$ & Performance Metric & $\begin{array}{l}\text { Potential Impact on Decision } \\
\text { if Performance Metric Not Met }\end{array}$ \\
\hline Precision & $\begin{array}{l}\text { At least } 80 \% \text { of the sample results for each } \\
\text { measured analyte are not qualified for } \\
\text { precision based on the RPD criteria as } \\
\text { specified in Section } 7.2 .1 \text {. }\end{array}$ & $\begin{array}{l}\text { If the performance metric is not met, the } \\
\text { affected analytical results from each affected } \\
\text { CAS will be assessed to determine whether } \\
\text { there is sufficient confidence in analytical } \\
\text { results to use the data in making DQO } \\
\text { decisions. }\end{array}$ \\
\hline Accuracy & $\begin{array}{l}\text { At least } 80 \% \text { of the sample results for each } \\
\text { measured analyte are not qualified for } \\
\text { accuracy based on the criteria specified in } \\
\text { Section } 7.2 .2 \text {. }\end{array}$ & $\begin{array}{l}\text { If the performance metric is not met, the } \\
\text { affected analytical results from each affected } \\
\text { CAS will be assessed to determine whether } \\
\text { there is sufficient confidence in analytical } \\
\text { results to use the data in making DQO } \\
\text { decisions. }\end{array}$ \\
\hline Sensitivity & $\begin{array}{l}\text { Laboratory detection limits are less than or } \\
\text { equal to respective FALs. }\end{array}$ & $\begin{array}{l}\text { Cannot determine whether COCs are present } \\
\text { or migrating at levels of concern. }\end{array}$ \\
\hline Comparability & $\begin{array}{l}\text { Sampling, handling, preparation, analysis, } \\
\text { reporting, and data validation are performed } \\
\text { using standard methods and procedures. }\end{array}$ & $\begin{array}{l}\text { Inability to combine data with data obtained } \\
\text { from other sources and/or inability to compare } \\
\text { data to regulatory action levels. }\end{array}$ \\
\hline Representativeness & $\begin{array}{l}\text { Samples contain contaminants at } \\
\text { concentrations present in the environmental } \\
\text { media from which they were collected. }\end{array}$ & $\begin{array}{l}\text { Analytical results will not represent true site } \\
\text { conditions. Inability to make appropriate DQO } \\
\text { decisions. }\end{array}$ \\
\hline Completeness & $\begin{array}{l}80 \% \text { of the CAS-specific COPC analytes } \\
\text { have valid results. } \\
100 \% \text { of CAS-specific targeted analytes } \\
\text { have valid results. }\end{array}$ & $\begin{array}{l}\text { Cannot support/defend decision on whether } \\
\text { COCs are present. }\end{array}$ \\
\hline Extent Completeness & $\begin{array}{l}100 \% \text { of COC analytes used to define } \\
\text { extent have valid results. }\end{array}$ & $\begin{array}{l}\text { Extent of contamination cannot be accurately } \\
\text { determined. }\end{array}$ \\
\hline $\begin{array}{l}\text { Clean Closure } \\
\text { Completeness }\end{array}$ & $\begin{array}{l}100 \% \text { of targeted analytes have valid } \\
\text { results. }\end{array}$ & $\begin{array}{l}\text { Cannot determine whether COCs remain in } \\
\text { soil. }\end{array}$ \\
\hline
\end{tabular}

$\mathrm{COC}=$ Contaminant of concern

$\mathrm{COPC}=$ Contaminant of potential concern

$\mathrm{DQO}=$ Data quality objective

$\mathrm{RPD}=$ Relative percent difference

assessment of chemical precision when both results are greater than or equal to $5 \mathrm{x}$ reporting limit (RL) is 20 percent and 35 percent for aqueous and soil samples, respectively. When either result is less than 5x RL, a control limit of $\pm 1 x$ RL and $\pm 2 x$ RL for aqueous and soil samples, respectively, is applied to the absolute difference.

The criteria used for the assessment of radiological precision when both results are greater than or equal to 5x MDC is 20 percent and 35 percent for aqueous and soil samples, respectively. When 
Table 7-2

Analytical Requirements for Radionuclides for CAU 177

\begin{tabular}{|c|c|c|c|c|c|c|}
\hline ParameterlAnalyte & Matrix & $\begin{array}{l}\text { Analytical } \\
\text { Method }\end{array}$ & MDC $^{a}$ & $P A L^{b, c}$ & $\begin{array}{c}\text { Laboratory } \\
\text { Precision (RPD) }\end{array}$ & $\begin{array}{l}\text { Percent } \\
\text { Recovery } \\
(\% \mathrm{R})\end{array}$ \\
\hline \multicolumn{7}{|c|}{ Gamma Spectroscopy } \\
\hline Americium-241 & Soil & HASL-300 & $2.0 \mathrm{pCi} / \mathrm{g}^{\mathrm{e}}$ & $12.7 \mathrm{pCi} / \mathrm{g}$ & \multirow{4}{*}{$\begin{array}{c}\text { Relative Percent } \\
\text { Difference (RPD) } \\
35 \% \\
\text { Normalized } \\
\text { Difference } \\
-2<N D<2^{\dagger}\end{array}$} & \multirow{4}{*}{$\begin{array}{c}\text { Laboratory } \\
\text { Control Sample } \\
\text { Recovery } \\
\text { 80-1209 Percent } \\
\text { Recovery (\%R) }\end{array}$} \\
\hline Cesium-137 & Soil & HASL-300 ${ }^{d}$ & $0.5 \mathrm{pCi} / \mathrm{g}^{\mathrm{e}}$ & $12.2 \mathrm{pCi} / \mathrm{g}$ & & \\
\hline Cobalt-60 & Soil & HASL-300 ${ }^{d}$ & $0.5 \mathrm{pCi} / \mathrm{g}^{\mathrm{e}}$ & $2.68 \mathrm{pCi} / \mathrm{g}$ & & \\
\hline Europium-152 & Soil & HASL-300 ${ }^{d}$ & $4.0 \mathrm{pCi} / \mathrm{g}^{\mathrm{e}}$ & $5.7 \mathrm{pCi} / \mathrm{g}$ & & \\
\hline \multicolumn{7}{|c|}{ Other Radionuclides } \\
\hline Plutonium-238 & Soil & $\begin{array}{c}\text { ASTM } \\
\text { C1001-00 }\end{array}$ & $0.05 \mathrm{pCi} / \mathrm{g}$ & $13.0 \mathrm{pCi} / \mathrm{g}$ & \multirow{6}{*}{$\begin{array}{c}\text { Relative Percent } \\
\text { Difference (RPD) } \\
35 \% \\
\text { Normalized } \\
\text { Difference } \\
-2<\mathrm{ND}<2^{\dagger}\end{array}$} & \multirow{6}{*}{$\begin{array}{c}\text { Laboratory } \\
\text { Control Sample } \\
\text { Recovery } \\
\text { 80-1209 Percent } \\
\text { Recovery (\%R) } \\
\\
\text { Chemical Yield } \\
30-105^{\mathrm{i}} \% \mathrm{R} \\
\text { (not applicable } \\
\text { for tritium) }\end{array}$} \\
\hline Plutonium-239/240 & Soil & $\begin{array}{c}\text { ASTM } \\
\text { C1001-00 }\end{array}$ & $0.05 \mathrm{pCi} / \mathrm{g}$ & $12.7 \mathrm{pCi} / \mathrm{g}$ & & \\
\hline Strontium-90 & Soil & HASL-300 ${ }^{d}$ & $0.5 \mathrm{pCi} / \mathrm{g}$ & $838 \mathrm{pCi} / \mathrm{g}$ & & \\
\hline Uranium-234 & Soil & $\begin{array}{c}\text { ASTM } \\
\text { C1000-02 }\end{array}$ & $0.05 \mathrm{pCi} / \mathrm{g}$ & $143 \mathrm{pCi} / \mathrm{g}$ & & \\
\hline Uranium-235 & Soil & $\begin{array}{c}\text { ASTM } \\
\text { C1000-02 }\end{array}$ & $0.05 \mathrm{pCi} / \mathrm{g}$ & $17.6 \mathrm{pCi} / \mathrm{g}$ & & \\
\hline Uranium-238 & Soil & $\begin{array}{c}\text { ASTM } \\
\text { C1000-02 }\end{array}$ & $0.05 \mathrm{pCi} / \mathrm{g}$ & $105 \mathrm{pCi} / \mathrm{g}$ & & \\
\hline
\end{tabular}

${ }^{a}$ The MDC is the lowest concentration of a radionuclide, if present in a sample, that can be detected with a 95 percent confidence level.

${ }^{\mathrm{b}}$ The PALs for soil are based on the National Council for Radiation Protection and Measurement (NCRP) Report No. 129 Recommended Screening Limits for Contaminated Soil and Review of Factors Relevant to Site-Specific Studies (NCRP, 1999) scaled to $25 \mathrm{mrem} / \mathrm{yr}$ dose and the guidelines for residual concentration of radionuclides in DOE Order 5400.5 (DOE, 1993).

'PALs for liquids will be developed as needed.

${ }^{\mathrm{d}}$ The Procedures Manual of the Environmental Measurements Laboratory, HASL-300 (DOE, 1997).

${ }^{\mathrm{e}} \mathrm{MDC}$ s vary depending on the presence of other gamma-emitting radionuclides in the sample and are relative to the MDC for cesium-137.

${ }^{f} \mathrm{ND}$ is not RPD, it is another measure of precision used to evaluate duplicate analyses. The ND is calculated as the difference between two results divided by the square root of the sum of the squares of their total propagated uncertainties. Evaluation of Radiochemical Data Usability (Paar and Porterfield, 1997).

${ }^{9}$ EPA Contract Laboratory Program Statement of Work for Inorganic Analysis (EPA, 1988a; 1994a; and 1995).

hStandard Test Method for Radiochemical Determination of Plutonium in Soil by Alpha Spectroscopy (ASTM, 2002).

'General Radiochemistry and Routine Analytical Services Protocol (GRASP) (EG\&G Rocky Flats, 1991). The chemical yield only applies to plutonium, uranium and strontium.

'Standard Test Method for Radiochemical Determination of Uranium Isotopes in Soil by Alpha Spectrometry (ASTM, 2000).

ASTM = American Society for Testing and Materials

$\mathrm{MDC}=$ Minimum detectable concentration

$\mathrm{mrem} / \mathrm{yr}=$ Millirem per year

ND $=$ Normalized difference

$\mathrm{PAL}=$ Preliminary action level

$\mathrm{pCi} / \mathrm{g}=$ Picocuries per gram 
Table 7-3

Analytical Requirements for Chemical COPCs for CAU 177* (Page 1 of 2)

\begin{tabular}{|c|c|c|c|c|c|}
\hline Parameter/Analyte & $\begin{array}{l}\text { Medium } \\
\text { or } \\
\text { Matrix }\end{array}$ & $\begin{array}{l}\text { Analytical } \\
\text { Method }\end{array}$ & $\begin{array}{c}\text { Minimum } \\
\text { Detectable } \\
\text { Concentration } \\
\text { (MDC) }\end{array}$ & $\begin{array}{l}\text { Laboratory } \\
\text { Precision } \\
\text { (RPD) }^{\mathrm{a}}\end{array}$ & $\begin{array}{c}\text { Percent } \\
\text { Recovery } \\
(\% \mathrm{R})^{\mathrm{b}}\end{array}$ \\
\hline \multicolumn{6}{|c|}{ ORGANICS } \\
\hline \multirow{2}{*}{ Total Volatile Organic Compounds } & Aqueous & \multirow{2}{*}{$8260 B^{c}$} & \multirow{2}{*}{$\begin{array}{l}\text { Parameter-specific } \\
\text { EQLs }^{\mathrm{d}}\end{array}$} & \multirow{2}{*}{ Lab-specific $^{\mathrm{e}}$} & \multirow{2}{*}{ Lab-specific $^{e}$} \\
\hline & Soil & & & & \\
\hline \multirow{2}{*}{$\begin{array}{l}\text { Total Semivolatile Organic } \\
\text { Compounds }\end{array}$} & Aqueous & \multirow{2}{*}{$8270 C^{c}$} & \multirow{2}{*}{$\begin{array}{l}\text { Parameter-specific } \\
\text { EQLs }^{d}\end{array}$} & \multirow{2}{*}{ Lab-specific $^{e}$} & \multirow{2}{*}{ Lab-specific $^{e}$} \\
\hline & Soil & & & & \\
\hline \multirow{2}{*}{ Polychlorinated Biphenyls } & Aqueous & \multirow{2}{*}{$8082^{c}$} & \multirow{2}{*}{$\begin{array}{l}\text { Parameter-specific } \\
\text { EQLs }^{f}\end{array}$} & \multirow{2}{*}{ Lab-specific $^{\mathrm{e}}$} & \multirow{2}{*}{ Lab-specific $^{\mathrm{e}}$} \\
\hline & Soil & & & & \\
\hline $\begin{array}{l}\text { Total Petroleum Hydrocarbons- } \\
\text { Gasoline-Range Organics }\end{array}$ & Soil & $\begin{array}{c}\text { 8015B } \\
\text { modified }^{c}\end{array}$ & $0.5 \mathrm{mg} / \mathrm{kg}^{\mathrm{g}}$ & Lab-specific $^{\mathrm{e}}$ & Lab-specific $^{\mathrm{e}}$ \\
\hline $\begin{array}{c}\text { Total Petroleum Hydrocarbons- } \\
\text { Diesel-Range Organics }\end{array}$ & Soil & $\begin{array}{c}\text { 8015B } \\
\text { modified }^{\mathrm{c}}\end{array}$ & $25 \mathrm{mg} / \mathrm{kg}^{\mathrm{g}}$ & Lab-specific $^{\mathrm{e}}$ & Lab-specific $^{e}$ \\
\hline \multicolumn{6}{|c|}{ INORGANICS } \\
\hline \multicolumn{6}{|c|}{ Total RCRA Metals, plus Beryllium } \\
\hline \multirow{2}{*}{ Arsenic } & Aqueous & $6010 B^{c}$ & $0.01 \mathrm{mg} / \mathrm{L}^{\mathrm{g}, \mathrm{h}}$ & \multirow{18}{*}{$\begin{array}{c}\text { RPD } 35 \%{ }^{\mathrm{g}} \\
\text { (soil) and } \\
20 \%{ }^{\mathrm{h}} \\
\text { (aqueous) } \\
\text { Absolute } \\
\text { Difference } \\
<2 \times \mathrm{xL} \text { (soil) } \\
\text { and <RL } \\
\text { (aqueous) }\end{array}$} & \multirow{18}{*}{$\begin{array}{c}\text { Matrix Spike } \\
\text { Recovery } \\
\text { at } \\
75-125^{\mathrm{h}}\end{array}$} \\
\hline & Soil & $6010 B^{c}$ & $1 \mathrm{mg} / \mathrm{kg}^{\mathrm{g}, \mathrm{h}}$ & & \\
\hline \multirow{2}{*}{ Barium } & Aqueous & $6010 B^{c}$ & $0.20 \mathrm{mg} / \mathrm{L}^{\mathrm{g}, \mathrm{h}}$ & & \\
\hline & Soil & $6010 B^{c}$ & $20 \mathrm{mg} / \mathrm{kg}^{\mathrm{g}, \mathrm{h}}$ & & \\
\hline \multirow{2}{*}{ Beryllium } & Aqueous & $6010 B^{c}$ & $0.005 \mathrm{mg} / \mathrm{L}^{\mathrm{g}, \mathrm{h}}$ & & \\
\hline & Soil & $6010 B^{c}$ & $0.5 \mathrm{mg} / \mathrm{kg}^{\mathrm{g}, \mathrm{h}}$ & & \\
\hline \multirow{2}{*}{ Cadmium } & Aqueous & $6010 B^{c}$ & $0.005 \mathrm{mg} / \mathrm{L}^{\mathrm{g}, \mathrm{h}}$ & & \\
\hline & Soil & $6010 B^{c}$ & $0.5 \mathrm{mg} / \mathrm{L}^{\mathrm{g}, \mathrm{h}}$ & & \\
\hline \multirow{2}{*}{ Chromium } & Aqueous & $6010 B^{c}$ & $0.01 \mathrm{mg} / \mathrm{L}^{\mathrm{g}, \mathrm{h}}$ & & \\
\hline & Soil & $6010 B^{c}$ & $1 \mathrm{mg} / \mathrm{kg}^{\mathrm{g}, \mathrm{h}}$ & & \\
\hline \multirow{2}{*}{ Lead } & Aqueous & $6010 B^{c}$ & $0.003 \mathrm{mg} / \mathrm{L}^{\mathrm{g}, \mathrm{h}}$ & & \\
\hline & Soil & $6010 B^{c}$ & $0.3 \mathrm{mg} / \mathrm{kg}^{\mathrm{g}, \mathrm{h}}$ & & \\
\hline \multirow{2}{*}{ Mercury } & Aqueous & $7470 A^{c}$ & $0.0002 \mathrm{mg} / \mathrm{L}^{\mathrm{g}, \mathrm{h}}$ & & \\
\hline & Soil & $7471 A^{c}$ & $0.1 \mathrm{mg} / \mathrm{kg}^{\mathrm{g}, \mathrm{h}}$ & & \\
\hline \multirow{2}{*}{ Selenium } & Aqueous & $6010 B^{c}$ & $0.005 \mathrm{mg} / \mathrm{L}^{\mathrm{g}, \mathrm{h}}$ & & \\
\hline & Soil & $6010 B^{c}$ & $0.5 \mathrm{mg} / \mathrm{kg}^{\mathrm{g}, \mathrm{h}}$ & & \\
\hline \multirow{2}{*}{ Silver } & Aqueous & $6010 B^{c}$ & $0.01 \mathrm{mg} / \mathrm{L}^{\mathrm{g}, \mathrm{h}}$ & & \\
\hline & Soil & $6010 B^{c}$ & $1 \mathrm{mg} / \mathrm{kg}^{\mathrm{g}, \mathrm{h}}$ & & \\
\hline
\end{tabular}




\section{Table 7-3 \\ Analytical Requirements for Chemical COPCs for CAU 177*}

(Page 2 of 2)

\begin{tabular}{||c|c|c|c|c|c|}
\hline Parameter/Analyte & $\begin{array}{c}\text { Medium } \\
\text { or } \\
\text { Matrix }\end{array}$ & $\begin{array}{c}\text { Analytical } \\
\text { Method }\end{array}$ & $\begin{array}{c}\text { Minimum } \\
\text { Detectable } \\
\text { Concentration } \\
\text { (MDC) }\end{array}$ & $\begin{array}{c}\text { Laboratory } \\
\text { Precision } \\
\text { (RPD) }\end{array}$ & $\begin{array}{c}\text { Percent } \\
\text { Recovery } \\
(\% R)^{\mathrm{b}}\end{array}$ \\
\hline
\end{tabular}

See Table 7-2 for the analytical requirements for radionuclides.

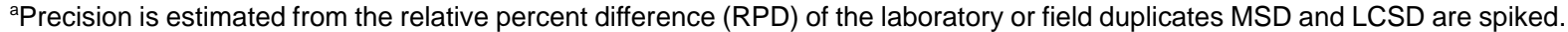
It is calculated by: $R P D=100 \times\left(\left|A_{1}-A_{2}\right|\right) /\left[\left(A_{1}+A_{2}\right) / 2\right]$, where $A_{1}=$ Concentration of the parameter in the initial sample aliquot, $A_{2}=$ Concentration of the parameter in the duplicate sample aliquot.

${ }^{\mathrm{b}}$ Accuracy is assessed from the percent recovery (\%R) of parameters spiked into a blank or sample matrix of interest, or from the recovery of surrogate compounds spiked into each sample. The recovery of each spiked parameter is calculated by: $\% R=100$ $x\left(A_{s}-A_{u} / A_{n}\right)$, where $A_{s}=$ Concentration of the parameter in the spiked sample, $A_{u}=$ Concentration of the parameter in the unspiked sample, $A_{n}=$ Concentration increase that should result from spiking the sample.

'U.S. EPA Test Methods for Evaluating Solid Waste Physical/Chemical Methods, 3rd Edition, Parts 1-4, (SW-846) CD ROM, Washington, DC (EPA,1996).

dEstimated Quantitation Limit as given in SW-846 (EPA, 1996).

${ }^{\mathrm{e}} \mathrm{RPD}$ and \%R Performance Criteria are developed and generated in-house by the laboratory according to approved laboratory procedures.

'EPA Contract Laboratory Program Statement of Work for Organic Analysis (EPA, 1988b, 1991, and 1994b).

9Industrial Sites Quality Assurance Project Plan (NNSA/NV, 2002).

hEPA Contract Laboratory Program Statement of Work for Inorganic Analysis (EPA, 1995).

$\mathrm{EQL}=$ Estimated quantitation limit

LCSD = Laboratory control sample duplicate

$\mathrm{mg} / \mathrm{L}=$ Milligrams per liter

$\mathrm{mg} / \mathrm{kg}=$ Milligrams per kilogram

MSD = Matrix spike duplicate

$\mathrm{N} / \mathrm{A}=$ Not applicable

RCRA = Resource Conservation and Recovery Act

either result is less than 5x MDC, the normalized difference (ND) should be between -2 and +2 for aqueous and soil samples.

Any values outside the specified criteria do not necessarily result in the qualification of analytical data. It is only one factor in making an overall judgment about the quality of the reported analytical results. The performance metric for assessing the DQI of precision on DQO decisions (see Table 7-1) is that at least 80 percent of sample results for each measured contaminant are not qualified due to duplicates exceeding the criteria. If this performance is not met, an assessment will be conducted in the investigation report on the impacts to DQO decisions specific to affected contaminants and CASs.

\subsubsection{Accuracy}

Accuracy is a measure of the closeness of an individual measurement to the true value. It is used to assess the performance of laboratory measurement processes. 
Accuracy is determined by analyzing a reference material of known parameter concentration or by reanalyzing a sample to which a material of known concentration or amount of parameter has been added (spiked). Accuracy will be evaluated based on results from three types of spiked samples: matrix spike (MS), LCS, and surrogate. The LCS is analyzed with the field samples using the same sample preparation, reagents, and analytical methods employed for the samples. One LCS will be prepared with each batch of samples for analysis by a specific measurement.

The criteria used for the assessment of inorganic chemical accuracy are 75 to 125 percent for MS recoveries and 80 to 120 percent for spiked LCS recoveries. For organic chemical accuracy, MS and spiked LCS laboratory-specific percent recovery criteria developed and generated in-house by the laboratory according to approved laboratory procedures are applied. The criteria used for the assessment of radiochemical accuracy are 80-120 percent for spiked LCS and MS recoveries.

Any values outside the specified criteria do not necessarily result in the qualification of analytical data. It is only one factor in making an overall judgment about the quality of the reported analytical results. Factors beyond laboratory control, such as sample matrix effects, can cause the measured values to be outside of the established criteria. Therefore, the entire sampling and analytical process may be evaluated when determining the usability of the affected data.

The performance metric for assessing the DQI of accuracy on DQO decisions (see Table 7-1) is that at least 80 percent of the sample results for each measured contaminant are not qualified for accuracy. If this performance is not met, an assessment will be conducted in the investigation report on the impacts to DQO decisions specific to affected contaminants and CASs.

\subsubsection{Representativeness}

Representativeness is the degree to which sample characteristics accurately and precisely represent a characteristics of a population or an environmental condition (EPA, 1987). Representativeness is assured by a carefully developing the sampling strategy during the DQO process such that false negative and false positive decision errors are minimized. 
The criteria listed in DQO Step 6 - Tolerable Limits on Decision Errors (see Section B.7.0) are:

- For Decision I judgmental sampling, having a high degree of confidence that the sample locations selected will identify COCs if present anywhere within the CAS.

- For Decision I probabilistic sampling, having a high degree of confidence that the sample locations selected will represent any contamination of the CAS.

- Having a high degree of confidence that analyses conducted will be sufficient to detect any COCs present in the samples.

- For Decision II, having a high degree of confidence that the sample locations selected will identify the extent of COCs.

These are qualitative measures that will be used to assess measurement system performance for representativeness. The assessment of this qualitative criterion will be presented in the Closure Report.

\subsubsection{Completeness}

Completeness is defined as generating sufficient data of the appropriate quality to satisfy the data needs identified in the DQOs. For judgmental sampling, completeness will be evaluated using both a quantitative measure and a qualitative assessment. The quantitative measurement to be used to evaluate completeness is presented in Table 7-1 and is based on the percentage of measurements made that are judged to be valid. The completeness goal for targeted analytes and the remaining COPCs is 100 percent and 80 percent, respectively. If these criteria are not achieved, the dataset will be assessed for potential impacts on making DQO decisions. The qualitative assessment of completeness is an evaluation of the sufficiency of information available to make DQO decisions. This assessment will be based on meeting the data needs identified in the DQOs and will be presented in the Closure Report.

For the probabilistic sampling approach, the completeness goal is the calculated minimum sample size required to produce a valid statistical comparison of the sample mean to the FAL. The methodology for determining the minimum required sample size is described in Appendix C. 


\subsubsection{Comparability}

Comparability is a qualitative parameter expressing the confidence with which one dataset can be compared to another (EPA, 1987). The criteria for the evaluation of comparability will be that all sampling, handling, preparation, analysis, reporting, and data validation were performed using approved standard methods and procedures. This will ensure that data from this project can be compared to regulatory action levels that were developed based on data generated using the same or comparable methods and procedures. An evaluation of comparability will be presented in the Closure Report.

\subsubsection{Sensitivity}

Sensitivity is the capability of a method or instrument to discriminate between measurement responses representing different levels of the variable of interest (EPA, 2001). The evaluation criteria for this parameter will be that measurement sensitivity (detection limits) will be less than or equal to the corresponding FALs. If this criterion is not achieved, the affected data will be assessed for usability and potential impacts on meeting site characterization objectives. This assessment will be presented in the Closure Report. 


\subsection{References}

AAS, see American Aerial Survey, Inc.

ASTM, see American Society for Testing and Materials.

American Aerial Survey, Inc. 1969. Aerial photograph U9BZ PRE TEST of the U-9bz emplacement hole, prior to detonation (CAS 09-09-41). 30 January.

American Society for Testing and Materials. 1995. Standard Guide for Risk-Based Corrective Action Applied at Petroleum Release Sites/American Society for Testing and Materials, ASTM E1739-95 (Reapproved 2002). Philadelphia, PA.

American Society for Testing and Materials. 2000. Standard Test Method for Radiochemical Determination of Uranium Isotopes in Soil by Alpha Spectroscopy, C1000-2000.

Philadelphia, PA.

American Society for Testing and Materials. 2002. Standard Test Method for Radiochemical Determination of Plutonium in Soil by Alpha Spectroscopy, C1001-2000. Philadelphia, PA.

BN, see Bechtel Nevada.

Bechtel Nevada. 1995. Nevada Test Site Performance Objective for Certification of Nonradioactive Hazardous Waste, G-E11/96.01, Rev. 0. Las Vegas, NV.

Bechtel Nevada. 2006. Redbook. As accessed at https://ntsweb.nv.doe.gov/apps/redbook/default.htm on 16 February. Las Vegas, NV.

CFR, see Code of Federal Regulations.

Carpenter, J., Los Alamos National Laboratory. 2001. Record of Telecon with B. Bailey (IT Corporation) regarding NTS Mud Pits. Las Vegas, NV.

Code of Federal Regulations. 2005a. Title 40 CFR, "Protection of the Environment," Parts 260-282, "Hazardous Waste Management System: General.” Washington, DC: U.S. Government Printing Office.

Code of Federal Regulations. 2005b. Title 40 CFR, "Protection of the Environment,” Parts 761, "PCBs." Washington, DC: U.S. Government Printing Office.

Code of Federal Regulations. 2005c. Title 40 CFR, Parts 763 “Protection of the Environment,” Parts 763, “Asbestos.” Washington, DC: U.S. Government Printing Office. 
DOE, see U.S. Department of Energy.

DOE/NV, see U.S. Department of Energy, Nevada Operations Office.

EG\&G, see EG\&G Energy Measurements, Inc.

EPA, see U.S. Environmental Protection Agency.

EG\&G Energy Measurements, Inc. 1989. NTS Yucca Flat Aerial Photograph Perf. \#6612-163. 23 September. U.S. Department of Energy.

EG\&G Rocky Flats. 1991. General Radiochemistry and Routine Analytical Services Protocol (GRASP), Version 2.1. July. Golden, CO.

FFACO, see Federal Facility Agreement and Consent Order.

Fahringer, P., Stoller-Navarro Joint Venture. 2005. Memorandum to A Gire and N. Nastanski (SNJV) entitled, “CAU 177 Geophysics- Memorandum of Findings,” 6 June. Las Vegas, NV.

Federal Facility Agreement and Consent Order. 1996 (as amended). Agreed to by the State of Nevada, the U.S. Department of Energy, and the U.S. Department of Defense.

LLNL, see Lawrence Livermore National Laboratory.

Lawrence Livermore National Laboratory. 1984. Postshot Drilling Handbook, January. Livermore, CA.

Moore, J. 1999. Memorandum to M. Todd (SAIC) entitled, "Background Concentrations for NTS and TTR Soil Samples,” 3 February. Las Vegas, NV: IT Corporation.

Murphy, T., Nevada Division of Environmental Protection. 2004. Letter to R.M. Bangerter, Jr. (NNSA/NSO) entitled, "Review of Industrial Sites Project Document 'Guidance for Calculating Industrial Sites Project Remediation Goals for Radionuclides in Soil Using the Residual Radiation (RESRAD) Computer Code,'” 19 November. Las Vegas, NV.

NAC, see Nevada Administrative Code.

NBMG, see Nevada Bureau of Mines and Geology.

NCRP, see National Council on Radiation Protection and Measurements.

NDEP, see Nevada Division of Environmental Protection.

NNSA/NSO, see U.S. Department of Energy, National Nuclear Security Administration Nevada Site Office. 
NNSA/NV, see U.S. Department of Energy, National Nuclear Security Administration Nevada Operations Office.

NRS, see Nevada Revised Statutes.

National Council on Radiation Protection and Measurements. 1999. Recommended Screening Limits for Contaminated Surface Soil and Review Factors Relevant to Site-Specific Studies, Report No. 129. Bethesda, MD.

Nevada Administrative Code. 2004a. NAC 444.570 - 444.7499, “Solid Waste Disposal.” Carson City, NV.

Nevada Administrative Code. 2004b. NAC 444.850 - 444.8746, “Disposal of Hazardous Waste.” Carson City, NV.

Nevada Administrative Code. 2004c. NAC 444.940-444.9555, “Polychlorinated Biphenyls.” Carson City, NV.

Nevada Administrative Code. 2004d. NAC 444.965-444.976, “Disposal of Asbestos.” Carson City, NV.

Nevada Administrative Code. 2005. NAC 445A.2272, “Contamination of Soil: Establishment of Action Levels.” Carson City, NV.

Nevada Bureau of Mines and Geology. 1998. Mineral and Energy Resource Assessment of the Nellis Air Force Range, Open-File Report 98-1. Reno, NV.

Nevada Division of Environmental Protection. 1995. Mutual Consent Agreement Between the State of Nevada and the U.S. Department of Energy for the Storage of Low-Level Land Disposal Restricted Mixed Waste, 7 June. Transmittal from P. Liebendorfer (NDEP) to D. Elle (DOE/NV). Carson City, NV.

Nevada Division of Environmental Protection. 1997a. Class II Solid Waste Disposal Site for Municipal and Industrial Solid Waste, Area 23 of the NTS, Permit SW 1309704. Carson City, NV.

Nevada Division of Environmental Protection. 1997b (as amended in August 2000). Class III Solid Waste Disposal Site for Hydrocarbon Burdened Soils, Area 6 of the NTS, Permit SW 1309702. Carson City, NV.

Nevada Division of Environmental Protection. 1997c (as amended in August 2000). Class III Solid Waste Disposal Site; U10C, Area 9 of the NTS, Permit SW 13097 03. Carson City, NV.

Nevada Division of Environmental Protection. 1999. State of Nevada Water Pollution Control General Permit, Permit No. GNEV93001. Carson City, NV. 
Nevada Revised Statutes. 2005a. NRS 444.440 - 444.620, "Collection and Disposal of Solid Waste." Carson City, NV.

Nevada Revised Statutes. 2005b. NRS 459.400 - 459.600, "Disposal of Hazardous Waste.” Carson City, NV.

Nevada Revised Statutes. 2005c. NRS 618.750 - 618.801, “Control of Asbestos.” Carson City, NV.

Nicosia, W., Shaw Environmental, Inc., 2003. Memorandum to M. England (Shaw) entitled, "Radiological Land Area Surveys of Summer 2003 Mud Pit Project at the Nevada Test Site," 1 August. Las Vegas, NV.

PNNL, see Pacific Northwest National Laboratory.

Paar, J.G., and D.R. Porterfield. 1997. Evaluation of Radiochemical Data Usability, April, ES/ER/MS-5.

Pacific Northwest National Laboratory. 2005. Visual Sample Plan Version 4.0 User’s Guide. September. PNNL-14002. Richland, WA.

REECo, see Reynolds Electrical \& Engineering Co., Inc.

Reynolds Electrical and Engineering Co., Inc. 1991. Inventory of Inactive and Abandoned Facilities and Waste Sites Areas 16-20, Volume 4 of 5. April. Las Vegas, NV.

Reynolds Electrical \& Engineering Co., Inc. 1994. Area 3 Waste Impoundment - Historical Information. Prepared by C.G. Postle. Las Vegas, NV.

SNJV, see Stoller-Navarro Joint Venture.

Stoller-Navarro Joint Venture. Date Unknown. Whitepaper: Assessment of NTS Mud Pit CASs in CAUs 530, 531, 532, 533, 534, and 535 That Are Potentially Contaminated with Radionuclides. 7 July. Las Vegas, NV.

Sorom, E.R., Reynolds Electrical \& Engineering Co., Inc. 1992. Memorandum to L. Whiteside (IT) entitled, "Contaminated Areas Report," 10 October. Las Vegas, NV.

USC, see United States Code.

USGS and DOE, see U.S. Geological Survey and U.S. Department of Energy.

United States Code. 1976. 15 USC 2601 et seq., “Toxic Substances Control Act,” Enacted by Public Law No. 94-469, as amended. Washington, DC: U.S. Government Printing Office. 
U.S. Department of Energy. 1993. DOE Order 5440.5, Change 2, Radiation Protection of the Public and the Environment. Washington, DC: U.S. Government Printing Office.

U.S. Department of Energy. 1997. The Procedures Manual of the Environmental Measurements Laboratory Procedures Manual, HASL-300, 28th Ed., Vol. I. New York, NY.

U.S. Department of Energy, National Nuclear Security Administration Nevada Operations Office. 2002. Industrial Sites Quality Assurance Project Plan, DOE/NV--372. Las Vegas, NV.

U.S. Department of Energy, National Nuclear Security Administration Nevada Site Office. 2003a. Closure Report for Corrective Action Unit 355: Area 2 Cellars/Mud Pits, Nevada Test Site, Nevada, DOE/NV--934-Rev. 0. November. Las Vegas, NV.

U.S. Department of Energy, National Nuclear Security Administration Nevada Site Office. 2003b. Closure Report for Corrective Action Unit 358: Area 18, 19, 20 Cellars/Mud Pits, Nevada Test Site, Nevada, Draft. November. Las Vegas, NV.

U.S. Department of Energy, National Nuclear Security Administration Nevada Site Office. 2004a. Mud Pit Risk-Based Closure Strategy Report, Nevada Test Site, Nevada, DOE/NV--991. Las Vegas, NV.

U.S. Department of Energy, National Nuclear Security Administration Nevada Site Office. 2004b. NV/YMP Radiological Control Manual, DOE/NV--11718-079, Rev. 5. Las Vegas, NV.

U.S. Department of Energy, National Nuclear Security Administration Nevada Site Office. 2005. Nevada Test Site Waste Acceptance Criteria, DOE/NV--325, Rev. 6. Las Vegas, NV.

U.S. Department of Energy, National Nuclear Security Administration Nevada Site Office. 2006. Industrial Sites Project Establishment of Final Action Levels. February. Las Vegas, NV.

U.S. Department of Energy, Nevada Operations Office. 1996. Radiological Effluents Released From U.S. Continental Tests 1961 through 1992. August. Las Vegas, NV.

U.S. Department of Energy, Nevada Operations Office. 1998. Evaluation of Potential Hydrocarbon Transport at the UC-4 Emplacement Hole, Central Nevada Test Area, DOE/NV-11508-43. Prepared by B.F. Lyles, G.Pohll, D.Sloop, C. Papelis. Las Vegas, NV.

U.S. Department of Energy, Nevada Operations Office. 2000a. Nevada Test Site Contaminated Land Areas Report, Volume I, DOE/NV/11718-481-Vol 1. December. Las Vegas, NV.

U.S. Department of Energy, Nevada Operations Office. 2000b. United States Nuclear Tests July 1945 through September 1992. December. Las Vegas, NV.

U.S. Department of Energy, Nevada Operations Office. 2001. Mud Pit Strategy, Nevada Test Site, Nevada, DOE/NV-684. Las Vegas, NV. 
U.S. Environmental Protection Agency. 1987. Data Quality Objectives for Remedial Response Activities, EPA/540/G-87/003. Washington, DC.

U.S. Environmental Protection Agency. 1988a. Contract Laboratory Program Statement of Work for Inorganic Analysis, SOW No. 788, EPA/540/R-94/093. Washington, DC.

U.S. Environmental Protection Agency. 1988b. Contract Laboratory Program Statement of Work for Organic Analysis, SOW No. 2/88, EPA/540/R-94//096. Washington, DC.

U.S. Environmental Protection Agency. 1991. Contract Laboratory Program Statement of Work for Organic Analysis, OLMO 1.8, EPA/540/R-94/078. Washington, DC.

U.S. Environmental Protection Agency. 1994a. Contract Laboratory Program Statement of Work for Inorganic Analysis, ILMO 3.0, EPA/540/R-94/076. Washington, DC.

U.S. Environmental Protection Agency. 1994b. Contract Laboratory Program Statement of Work for Organic Analysis, OLMO 3.1, EPA/540/R-94/073. Washington, DC.

U.S. Environmental Protection Agency. 1995. Contract Laboratory Program Statement of Work for Inorganic Analysis, ILMO 4.0, EPA/540/R-95/121. Washington, DC.

U.S. Environmental Protection Agency. 1996. Test Methods for Evaluating Solid Waste, Physical/Chemical Methods, SW-846, $3^{\text {rd }}$ Edition (which includes updates to 1986, 1992, and 1994 revisions), CD-ROM PB97-501928GEI. Washington, DC.

U.S. Environmental Protection Agency. 2001. Guidance on Data Quality Indicators, EPA QA/G-5i. Washington, DC.

U.S. Environmental Protection Agency. 2002. Data Quality Objectives Process for Hazardous Waste Site Investigations. EPA QA/G4. Washington, DC.

U.S. Environmental Protection Agency. 2004. EPA Region 9 Preliminary Remediation Goals (PRGs). As accessed at http://www.epa.gov/region09/waste/sfund/prg/index.html on 2 February 2006. San Francisco, CA.

U.S. Geological Survey and U.S. Department of Energy. 2005. “USGS/USDOE Cooperative Studies in Nevada Periodic Water Levels -- Nevada Test Site Map.” As accessed at http://nevada.usgs.gov/doe_nv/doe_nv/ntsmap.htm on 2 February 2006.

Wilkes, M., Bechtel Nevada. 2000a. Record of meeting with B. Bailey (IT) regarding mud pits at the NTS, 3 November. Las Vegas, NV.

Wilkes, M., Bechtel Nevada. 2000b. Record of meeting with B. Bailey (IT) regarding mud pits at the NTS, 9 November. Las Vegas, NV. 
CAU 177 SAFER Plan

Section: 8.0

Revision: 0

Date: June 2006

Page 73 of 73

Witt, J., Science Applications International Corporation. 2000. Record of meeting with B. Bailey (IT) concerning mud pit usage, 19 October. Las Vegas, NV. 


\section{Appendix A \\ Project Organization}




\section{A.1 Project Organization}

The NNSA/NSO Acting Federal Sub-Project Director and the NNSA/NSO Task Manager is Sabine Curtis. She can be contacted at (702) 295-0461.

The identification of the project Health and Safety Officer and the QA Officer can be found in the appropriate plan. However, personnel are subject to change and it is suggested that the appropriate DOE Project Manager be contacted for further information. The Task Manager will be identified in the FFACO Monthly Activity Report before the start of field activities. 


\section{Appendix B \\ Data Quality Objective Process}




\section{B.1.0 Introduction}

The DQO process described in this appendix is a seven-step systematic planning process based on the scientific method that was used to plan data collection activities and define performance criteria for the CAU 177, Mud Pits and Cellars, field investigation. The DQOs are designed to ensure that the data collected will provide sufficient and reliable information to determine the appropriate corrective actions, to verify the adequacy of existing information, to provide sufficient data to implement the corrective actions, and to verify that closure was achieved.

The seven steps of the DQO process presented in Sections B.2.0 through B.8.0 were developed in accordance with EPA Guidance for the Data Quality Objectives Process (EPA QA/G-4) (EPA, 2000b) and EPA Guidance for Quality Assurance Project Plans (EPA QA/G-5) (EPA, 2002b). The DQO process presented herein is based on the EPA Quality System Document for DQOs entitled Data Quality Objectives Process for Hazardous Waste Site Investigations (EPA QA/G-4HW) (EPA, 2000a) and the CAS-specific information presented in Section B.2.0.

In general, the procedures used in the DQO process provide:

- A scientific basis for making inferences about a site (or portion of a site) based on environmental data or process knowledge

- A basis for defining decision performance criteria and assessing the achieved decision quality of the data collection design

- Criteria for knowing when site investigators should stop data collection (i.e., when sufficient information is available to support decisions)

- A basis for demonstrating an acceptable level of confidence in the sampling approach to generate the appropriate quantity and quality of information necessary to minimize the potential for making decision errors 


\section{B.2.0 Step 1 - State the Problem}

The problem statement for CAU 177 is: "Existing information on the nature and extent of potential contamination is insufficient to validate the assumptions used to select the corrective action alternatives of NFA or closure in place, or to verify that closure objectives were met.”

\section{B.2.1 Planning Team Members}

The DQO planning team consists of representatives from NDEP, NNSA/NSO, Stoller-Navarro Joint Venture (SNJV), and Bechtel Nevada (BN). The primary decision-makers are the NDEP and NNSA/NSO representatives. Table B.2-1 lists representatives from each organization in attendance at the February 21, 2006, DQO meeting.

Table B.2-1

Data Quality Objective Meeting Participants for CAU 177

February 21, 2006

(Page 1 of 2)

\begin{tabular}{|c|c|}
\hline Affiliation & Department/Project Team Function \\
\hline NDEP & NDEP Representative \\
\hline NNSA/NSO & $\begin{array}{c}\text { Environmental Restoration Project Federal Industrial Sites Sub-Project Task } \\
\text { Manager }\end{array}$ \\
\hline $\mathrm{BN}$ & Environmental Restoration Deputy Project Manager \\
\hline $\mathrm{BN}$ & Environmental Restoration Field Support Manager \\
\hline SNJV & Industrial Sites Project Manager \\
\hline SNJV & Industrial Sites Technical Coordinator \\
\hline SNJV & Industrial Sites (CAU 177) Task Co-leads (2) \\
\hline SNJV & Federal Facility Agreement and Consent Order Representative \\
\hline SNJV & Quality Assurance Representative \\
\hline SNJV & Analytical Services Chemical Data Validator \\
\hline SNJV & Analytical Services Radiological Data Validator \\
\hline SNJV & Health and Safety Group Representative \\
\hline SNJV & Environmental Compliance and Waste Management Representative \\
\hline SNJV & Radiation Services Health Physicist \\
\hline
\end{tabular}




\section{Table B.2-1 \\ Data Quality Objective Meeting Participants for CAU 177 \\ February 21, 2006}

(Page 2 of 2)

\begin{tabular}{|c|c|}
\hline Affiliation & Department/Project Team Function \\
\hline
\end{tabular}

BN = Bechtel Nevada

NDEP = Nevada Division of Environmental Protection

NNSA/NSO = U.S. Department of Energy, National Security Administration Nevada Site Office

SNJV = Stoller-Navarro Joint Venture

\section{B.2.2 Conceptual Site Model}

The CSM is used to organize and communicate information about site characteristics. It reflects the best interpretation of available information at any point in time. The CSM is a primary vehicle for communicating assumptions about release mechanisms, potential migration pathways, or specific constraints. It provides a summary of how and where contaminants are expected to move, and what impacts such movement may have. It is the basis for assessing how contaminants could reach receptors both in the present and future. The CSM describes the most probable scenario for current conditions at each site and defines the assumptions that are the basis for identifying appropriate sampling strategy and data collection methods. Accurate CSMs are important as they serve as the basis for all subsequent inputs and decisions throughout the DQO process.

The CSM was developed for CAU 177 using information from the physical setting, potential contaminant sources, release information, historical background information, knowledge from similar sites, and physical and chemical properties of the potentially affected media and COPCs.

The CSM represents contamination of the surrounding environment due to migration of contaminants that either are currently, or were formerly, present at each of the CASs. Migration of contaminants to areas not presently impacted can occur through infiltration and percolation of contaminants into the soil profile, lateral transportation (overland flow) of some contaminants as a result of surface water runoff or overflow of accumulated surface water in mud pits or cellars, or wind-borne resuspension of contaminated surface particles. 
The CSM consists of:

- Potential contaminant releases, including media subsequently affected

- Release mechanisms (the conditions associated with the release)

- Potential contaminant source characteristics, including contaminants suspected to be present

- Site characteristics, including physical and meteorological information

- Migration pathways and transport mechanisms that describe the potential for migration and where the contamination may be transported

- The locations of points of exposure where individuals or populations may come in contact with a COC associated with a CAS

- Routes of exposure

If additional elements are identified during the investigation that are outside the scope of this CSM, the situation will be reviewed and a recommendation will be made as to how to proceed. In such cases, NDEP and NNSA/NSO will be notified and given the opportunity to comment on and concur with the recommendation.

The applicability of this CSM to the mud pits and cellars is summarized in Table B.2-2 and discussed below. Table B.2-2 provides information on CSM elements that will be used throughout the remaining steps of the DQO process. Figure B.2-1 represents site conditions applicable to the CSM.

\section{B.2.2.1 Contaminant Release}

The mud pits and cellars of CAU 177 are suspected to contain radiologically contaminated media generated by activities associated with nuclear testing. With the exception of two mud pits from which preliminary sample results indicate radiological contamination, the only indication of radiological contamination at the other CASs is the posting or former posting of Underground RMA signage.

There have been no inorganic or organic COPCs identified for NTS mud pits based on the conclusions of the Mud Pit Risk-Based Closure Strategy Report (RBCSR) (NNSA/NSO, 2004) and the available documentation from the investigation of CAUs 530-535, Mud Pits. Results of the 
Table B.2-2

Conceptual Site Model Description of Elements for All CASs in CAU 177

(Page 1 of 2)

\begin{tabular}{|c|c|}
\hline CAS Description & Mud Pits and Cellars \\
\hline CAU Status & Sites are inactive and abandoned \\
\hline Future Land Use & Nuclear and High Explosives Test Zone (DOE/NV, 1998b) \\
\hline $\begin{array}{c}\text { Sources of } \\
\text { Potential Soil } \\
\text { Contamination }\end{array}$ & $\begin{array}{l}\text { Mud Pit: Primary source for radiological contamination is a release of drilling mud associated with } \\
\text { post-test drilling activities subsequent to underground nuclear testing. Other contributors to } \\
\text { contamination may include a release of radiological effluents from an underground test, or fallout } \\
\text { from an atmospheric test. Organic or inorganic contamination is not expected at mud pits. } \\
\text { Cellar: Primary source for chemical contamination is a direct release of drill rig fluids (hydraulic } \\
\text { fluid, oils, greases, diesel fuel). Other contributors may include the decontamination of drilling } \\
\text { equipment over the cellar cavity, or discarding of potentially hazardous drilling materials. The } \\
\text { primary source for radiological contamination is an accidental release of contaminated drilling mud } \\
\text { via spills, or leaks from drilling hoses or tubing. Other contributors may include a release of } \\
\text { radiological effluents from an underground test, or fallout from an atmospheric test. }\end{array}$ \\
\hline $\begin{array}{l}\text { Location of } \\
\text { Contamination/ } \\
\text { Release Point }\end{array}$ & $\begin{array}{l}\text { Mud Pit: Residual drilling mud contained within the boundaries of the mud pit walls/berms, or at } \\
\text { drilling mud spills adjacent to the mud pit. If a backfilled mud pit, the mud would be located directly } \\
\text { beneath the cover material (typically } 4-5 \mathrm{ft} \text { bgs). } \\
\text { Cellar: Surface and shallow subsurface soils at the base of the cellar (typically } 10-12 \mathrm{ft} \text { bgs) } \\
\text { contained within the boundaries of the corrugated metal casing (typically } 10 \mathrm{ft} \text { in diameter). }\end{array}$ \\
\hline Amount Released & Unknown \\
\hline Affected Media & $\begin{array}{l}\text { Mud Pit: Residual mud contained in the boundaries of the mud pit. Underlying soils are not } \\
\text { expected to have been affected due to properties of drilling mud. } \\
\text { Cellar: Surface and shallow subsurface soil at the base of the cellar. }\end{array}$ \\
\hline $\begin{array}{c}\text { Potential } \\
\text { Contaminants }\end{array}$ & $\begin{array}{l}\text { Mud Pit: Limited to radionuclides (gamma-emitters, isotopic uranium, plutonium, and } \\
\text { strontium-90). } \\
\text { Cellar: Contaminants include VOCs, SVOCs, PCBs, metals, TPH, and radionuclides } \\
\text { (gamma-emitters, isotopic uranium, plutonium, and strontium-90). }\end{array}$ \\
\hline $\begin{array}{c}\text { Transport } \\
\text { Mechanisms }\end{array}$ & $\begin{array}{l}\text { - Infiltration and percolation of precipitation through affected media serves as the major } \\
\text { driving force for contamination to migrate vertically. Due to the low precipitation and high } \\
\text { evaporation rates of the arid environment, percolation of infiltrated precipitation is limited } \\
\text { and is not considered a significant mechanism regarding the transport of contaminants to } \\
\text { groundwater. } \\
\text { - Lateral transportation of some contaminants may occur as a result of surface water runoff } \\
\text { or overflow of surface water accumulated in the mud pits and cellars. } \\
\text { - Evaporation of volatile components may release contaminants to the air. } \\
\text { - Wind blowing over open mud pits and cellars may resuspend contaminated surface soil } \\
\text { particles. }\end{array}$ \\
\hline
\end{tabular}


Table B.2-2

Conceptual Site Model Description of Elements for All CASs in CAU 177

(Page 2 of 2)

\begin{tabular}{|c|c|c|c|}
\hline CAS Description & \multicolumn{3}{|c|}{ Mud Pits and Cellars } \\
\hline $\begin{array}{l}\text { Migration } \\
\text { Pathways }\end{array}$ & \multicolumn{3}{|c|}{$\begin{array}{l}\text { - Vertical migration of contaminants through the affected media in mud pits and cellars is } \\
\text { considered insignificant due to the arid climate of the Nevada Test Site. Cover material } \\
\text { for backfilled mud pits and cellars could also significantly prevent percolation of } \\
\text { precipitation as a driving force. Also, vertical migration of contaminants through drilling } \\
\text { mud into the underlying soil is not expected due to the physical properties of the drilling } \\
\text { mud. } \\
\text { - Without a breach in the berms of a mud pit, or a large rainfall event that would cause } \\
\text { overtopping of the mud pit or cellar, potential lateral migration, or overland flow is } \\
\text { considered to be limited. } \\
\text { Evaporation as a migration pathway would only be applicable to open cellars; however, } \\
\text { this pathway is considered insignificant because the volatile components of TPH are } \\
\text { expected to have weathered away. Contaminants of potential concern for mud pits do not } \\
\text { include vapor phases. Previous sampling has eliminated VOCs as COPCs for mud pits. } \\
\text { Wind transport of resuspended particles is considered an insignificant pathway because } \\
\text { the affected media in mud pits and cellars is protected by berms and } 10-12 \mathrm{ft} \text { bgs metal } \\
\text { casing, respectively. A release of contaminants to the air is not considered a complete } \\
\text { migration pathway for mud pits and cellars that have been backfilled because the affected } \\
\text { media is covered. }\end{array}$} \\
\hline $\begin{array}{l}\text { Lateral and } \\
\text { Vertical Extent of } \\
\text { Contamination }\end{array}$ & $\begin{array}{l}\text { - The la } \\
\text { of the } \\
\text { The la } \\
\text { that st } \\
\text { - The ve } \\
\text { expec } \\
\text { Conta } \\
\text { be exp } \\
\text { contar } \\
\mathrm{ft} \text { bgs }\end{array}$ & $\begin{array}{l}\text { xtent of contamination in mud } p \\
t \text { unless there is a noticeable } b \\
\text { xtent of contamination in cellar } \\
\text { Is the cellar cavity. } \\
\text { extent of potential contaminatic } \\
\text { nfiltrate more than a few inche } \\
\text { n at a mud pit is expected to b } \\
\text { to migrate vertically downward } \\
n \text { is not expected because dep } \\
\text { erages approximately } 800 \mathrm{ft} b\end{array}$ & $\begin{array}{l}\text { s expected to be limited to the walls/berms } \\
\text { ch that would allow for overland transport. } \\
\text { expected to be limited by the metal casing } \\
\text { the affected media of a cellar is not } \\
\text { low the base of cellar, if at all. } \\
\text { und within the residual mud and would not } \\
\text { the underlying soil. Groundwater } \\
\text { groundwater varies between } 500 \text { to } 2,800 \\
\text { JSGS/DOE, 2005). }\end{array}$ \\
\hline $\begin{array}{l}\text { Exposure } \\
\text { Scenario }\end{array}$ & $\begin{array}{l}\text { The ex } \\
\text { occas } \\
\text { worke } \\
\text { the sit } \\
\text { visit b } \\
\text { scena } \\
\text { the fut } \\
\text { categc } \\
\text { - A site } \\
\text { equive }\end{array}$ & $\begin{array}{l}\text { scenario for all CASs is the O } \\
\text { ork activities at a site. This Sc } \\
\text { are not assigned to the area a } \\
\text { scenario assumes that this is } \\
\text { occasionally use for short-tern } \\
\text { lat it is a remote area with no a } \\
\text { id use designation is for outdo } \\
\text { as the Nuclear and High Explo } \\
\text { under the Occasional Use Are } \\
80 \text { hours (or } 10 \text { days) per yea }\end{array}$ & $\begin{array}{l}\text { sional Use Area Scenario, which assumes } \\
\text { rio addresses exposure to industrial } \\
\text { regular worksite but may occasionally use } \\
\text { area where the worker does not regularly } \\
\text { tivities. The criteria for this exposure } \\
\text { e improvements (NNSA/NSO, 2006) and } \\
\text { sts and/or military training exercises, } \\
\text { s Test Zone (DOE, 1998b). } \\
\text { cenario is assumed to be on the site for an } \\
5 \text { years (NNSA/NSO, 2006) }\end{array}$ \\
\hline $\begin{array}{l}\text { bgs }=\text { Below ground su } \\
\text { COPC = Contaminant }\end{array}$ & ntial concern & $\begin{array}{l}\mathrm{ft}=\text { Foot } \\
\mathrm{PCB}=\text { Polychlorinated biphenyl }\end{array}$ & $\begin{array}{l}\text { SVOC = Semivolatile organic compound } \\
\text { TPH = Total petroleum hydrocarbons } \\
\text { VOC = Volatile organic compound }\end{array}$ \\
\hline
\end{tabular}




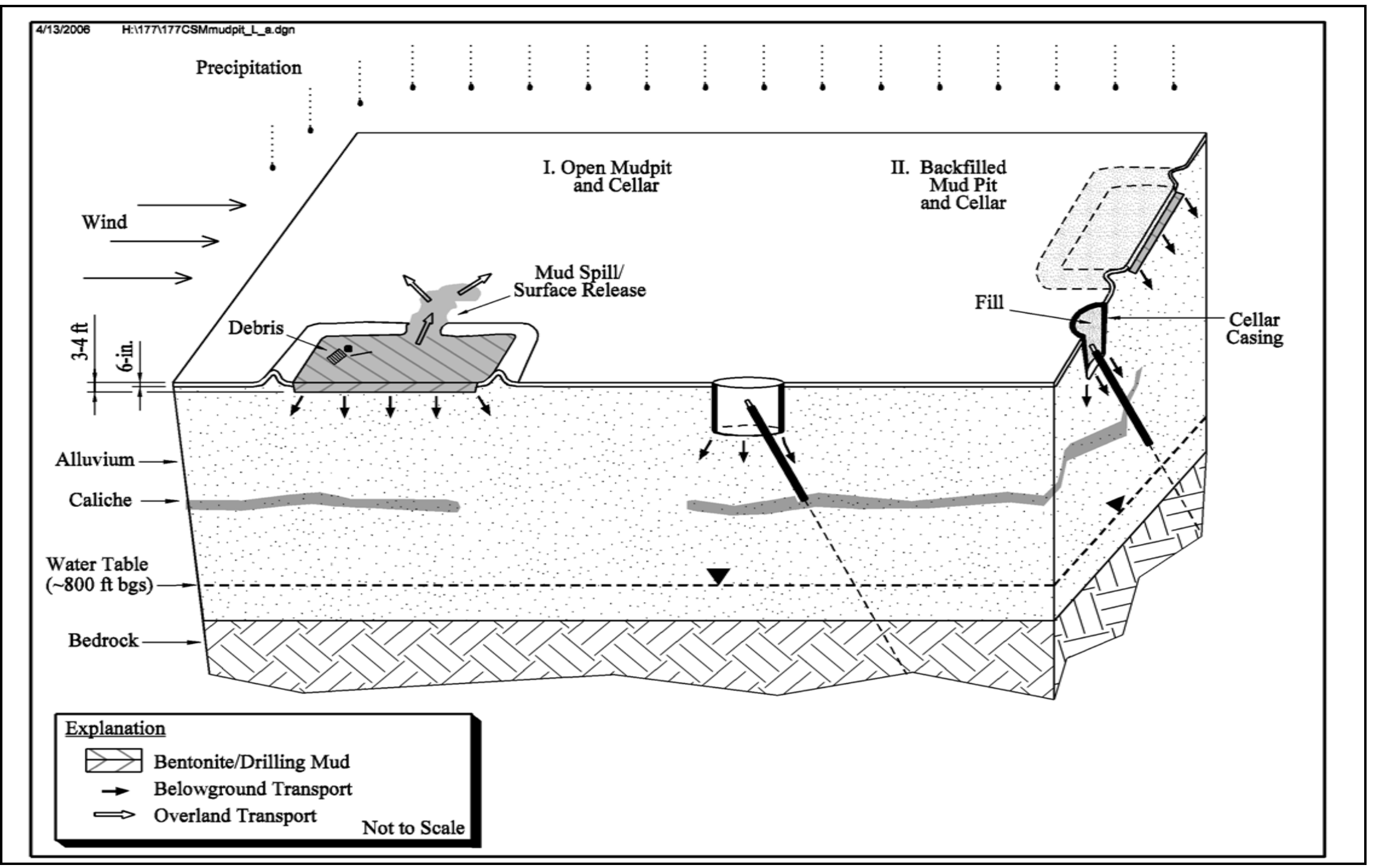

Figure B.2-1

Conceptual Site Model for CAU 177 
RBCSR have eliminated VOCs, semivolatile organic compounds (SVOCs), PCBs, and metals as COPCs from NTS mud pits based on the conclusion that there is no analytical or process knowledge to suggest these constituents are present at significant concentrations in residual mud. Although the risk assessment concluded that TPH does not pose an unacceptable risk to human health or the environment, it was the most frequently detected contaminant in residual mud. To be conservative, it was determined that the investigation of CAUs 530-535 would further evaluate the risk posed by TPH-DRO, the only COPC, and would verify the closure strategy of NFA for NTS mud pits. It was determined that sampling 52 of the 268 CASs would be an acceptable number to represent the entire population of mud pits (NNSA/NSO, 2005). Sampling results from this investigation have verified that TPH-DRO does not pose an unacceptable risk to human health or the environment, and therefore it is eliminated as a COPC for CAU 177 mud pits.

Because complete information regarding activities performed at the CAU 177 cellars is not available, chemical constituents will be included as COPCs in addition to radionuclides in order to fully characterize cellars and to reduce the uncertainty. As a result, this investigation will provide preliminary data for characterizing other identified cellars that may be included in future corrective action investigations.

The process associated with potential contamination at a mud pit is not the same process that may have contributed to contamination at a cellar. Therefore, the following sections will address the release of contaminants associated with each feature separately.

\section{B.2.2.1.1 Mud Pits}

The primary source of potential radiological contamination is the release of drilling mud that may have been in contact with radioactive rock and circulated from the borehole to the mud pit during post-test drilling. Process knowledge indicates that bentonite clay is a major ingredient in drilling mud (IMANA, 2004). In general, clay minerals have high porosity, low permeability, and the property of expanding several times its original volume when saturated with water. This clay-water mixture has a viscosity several times that of water, making it useful as a drilling fluid (DOE/NV 1998a). Based on the unique properties of bentonite and its prominent occurrence in drilling mud, it is believed that its use would help retard the migration of COPCs present in the mud. Furthermore, the layer of residual drilling mud contained within the mud pit is expected to act as a barrier to 
prevent the downward migration of contaminants into underlying native soil. The document Evaluation of Potential Hydrocarbon Transport at the UC-4 Emplacement Hole, Central Nevada Test Area (DOE/NV, 1998a) reports data that support the conclusion that contamination within drilling mud does not migrate significantly based on TPH release experiments.

The locations for a release of drilling mud are at the base of the excavated mud pit, or at drilling mud spills adjacent to the pits. The media affected by a release is typically the surface and shallow subsurface soil; however, due to the binding properties of bentonite, contamination is expected to be bound within the mud with no migration to the native soil adjacent to the floor and walls of the mud pits. Contamination, if any, is expected to be evenly dispersed and present at relatively uniform concentrations because the mud was homogenized as it was circulated. This suggests that surface samples of the residual mud would be representative of the mud throughout the depth of the mud pit. Contamination unrelated to the mud pit process may be localized beneath potentially hazardous discarded drilling materials, if present.

\section{B.2.2.1.2 Cellars}

A release of radiological or chemical contaminants to media within a cellar is not expected based on cellar processes; however, contamination, if any, can be attributed to accidental spills and leaks, or materials discarded during drilling activities.

The primary source of a release of radionuclides is suspected to be from radiologically contaminated drilling mud that either spilled or leaked into the cellar cavity as a result of careless activities or a failure of the circulation system. Typically, a release of drilling mud to the cellar would not occur because the drilling mud was recirculated from the borehole to the mud pit through a closed system. Although unlikely, another potential contributor of radiological contamination is a release of radiological effluents from underground tests through a vent or fissure, or fallout from an atmospheric test. The primary source of a chemical contaminant release is suspected to be from drill rig fluids such as hydraulic fluid, oils, greases, and potentially diesel fuel that was directly introduced to the cellar cavity through either spills or leaks, decontamination of drilling equipment over the cellar cavity, or discarded drilling materials. The organic components of these materials would show up in the analyses as VOCs, SVOCs, PCB, and TPH. If TPH is detected, the source may be either from 
drilling fluid known to contain diesel fuel as an additive (DOE/NV, 2001; NNSA/NSO, 2004), or from fluids associated with the drill rig as described above.

A release of either radiological or chemical contamination is expected to be located at the base of the cellar (typically 10 to $12 \mathrm{ft}$ bgs) and contained within the boundaries of the corrugated metal casing (typically $10 \mathrm{ft}$ in diameter). The affected media is expected to be the surface and shallow subsurface soil at the cellar bottom. Soil outside of the 10- to 12-ft-deep cellar casing is not expected to have been impacted because the casing acts as a barrier to contaminant migration. In the event of a release immediately adjacent to the cellar, the concrete foundation that surrounds the cellar casing would provide a barrier to contaminants migrating into the underlying soil. Contamination, if present, is expected to be contiguous to the respective release locations described for cellars and is expected to decrease with horizontal and vertical distance from the source.

Groundwater contamination is not considered a likely scenario at any CAS based on the depth to groundwater in Areas 8, 9, 19, and 20. Data from nearest wells indicate that groundwater levels are approximately 2,000 ft bgs for Area 8 CASs, may range from approximately 500 to 2,000 ft bgs for Area 9 CASs, and may range from 2,100 to 2,800 ft bgs for Area 19 and 20 CASs (USGS/DOE, 2005). Surface migration is not expected to be significant because the engineered structure of a mud pit and cellar would limit surface migration to within the physical barriers (i.e, mud pit berms and cellar casing).

\section{B.2.2.2 Potential Contaminants}

The COPCs for CAU 177 are defined as the analytes reported from the analyses identified in Table B.2-3. The analyses to be conducted are not CAS specific, but rather are dependent on whether a release is associated with the mud pit process or the cellar process because the targeted analytes vary for each of these processes. The list of COPCs is applicable to Decision I environmental samples from each mud pit and cellar, and is intended to encompass all of the contaminants that could potentially be present. These contaminants were identified during the planning process through the review of site history, process knowledge, personal interviews, past investigation efforts (where available), and inferred activities associated with the mud pit and cellar processes. Because complete information regarding activities performed at the cellars of CAU 177 is not available, contaminants 
Table B.2-3

Analytical Program ${ }^{\mathrm{a}}$

\begin{tabular}{|c|c|c|}
\hline Analyses $^{b}$ & Mud Pits & Cellars \\
\hline \multicolumn{3}{|c|}{ Organic COPCs } \\
\hline Total Petroleum Hydrocarbons-Diesel-Range Organics & --- & $\mathrm{X}$ \\
\hline Total Petroleum Hydrocarbons-Gasoline-Range Organics & --- & $\mathrm{X}$ \\
\hline Polychlorinated Biphenyls & --- & $\mathrm{X}$ \\
\hline Semivolatile Organic Compounds ${ }^{c}$ & --- & $\mathrm{x}$ \\
\hline Volatile Organic Compounds ${ }^{c}$ & --- & $x$ \\
\hline \multicolumn{3}{|c|}{ Inorganic COPCs } \\
\hline Total Resource Conservation and Recovery Act Metals ${ }^{c}$ & --- & $x$ \\
\hline Total Beryllium & --- & $\mathrm{X}$ \\
\hline \multicolumn{3}{|c|}{ Radionuclide COPCs } \\
\hline Gamma Emitters & $x$ & $\mathrm{X}$ \\
\hline Isotopic Uranium & $x$ & $x$ \\
\hline Isotopic Plutonium & $x$ & $x$ \\
\hline Strontium-90 & $x$ & $x$ \\
\hline
\end{tabular}

\footnotetext{
aThe contaminants of potential concern are the analytes reported from the analytical methods listed.

bIf the volume of material is limited, prioritization of the analyses will be necessary.

"May also include Toxicity Characteristic Leaching Procedure analytes if sample is collected for waste management purposes.

$X=$ Required analytical method

--- = Analyses will not be performed at this feature.

COPC $=$ Contaminant of potential concern
}

commonly detected at other similar NTS sites were included in the contaminant list to reduce the uncertainty.

Some COPCs are identified as targeted analytes, which are those contaminants for which evidence and/or process information suggests that they are reasonably suspected to be present at a given CAS. The targeted analytes are required to meet a more stringent completeness criteria than other COPCs thus providing greater protection against a decision error (see Section B.7.0). For this investigation, Eu-152 and Pu-239 have been identified as targeted analytes based on sampling results from a previous investigation of CAS 09-09-41 and CAS 09-09-45 (SNJV, Date Unknown). Europium-152 (CASs 09-09-41 and 09-09-45) and Pu-239 (CAS 09-09-45) were detected at concentrations that 
exceeded PALs in both surface (0 to 3 in.) and near surface (3 to 6 in.) soil samples, which demonstrates that contamination cannot be attributed solely to fallout from atmospheric testing. In addition to these radionuclides, any Decision II COC will also be treated as a targeted analyte. Targeted analytes for mud pits and cellars are identified in Table B.2-4.

Table B.2-4

Targeted Analytes for CAU 177

\begin{tabular}{|c|c|c|}
\hline Feature & Chemical Targeted Analyte(s) & Radiological Targeted Analyte(s) $^{\mathbf{a}}$ \\
\hline \hline Mud Pit & None & Europium-152, Plutonium-239 \\
\hline Cellar & None & Europium-152, Plutonium-239 \\
\hline
\end{tabular}

${ }^{\text {a }}$ The evidence for radiological target analytes at mud pits and cellars is from previous sampling results of CAS 09-09-41 and CAS 09-09-45. See Sections 2.3.3 and 2.4.3.

Source: SNJV, Date Unknown

\section{B.2.2.3 Contaminant Characteristics}

Contaminant characteristics include, but are not limited to: solubility, density, and adsorption potential. In general, contaminants with large particle size, low solubility, high affinity for media, and/or high density can be expected to be found relatively close to release points. Contaminants with small particle size, high solubility, low affinity for media, and/or low density are found further from release points or in low areas where evaporation of ponding will concentrate dissolved contaminants.

\section{B.2.2.4 Site Characteristics}

Site characteristics are the physical, topographical, and meteorological attributes and properties. Table B.2-5 lists the physical setting of the CAU 177 CASs. Listed for each CAS is whether it contains a mud pit, a cellar, or both, and whether that feature has been backfilled or left open. The practice of backfilling these features appears to be arbitrary and should only impact sampling logistics, hazard controls, and potentially migration pathways. In general, the mud pits and cellars are expected to have similar characteristics because they were all constructed within the surface and shallow subsurface soil of the NTS using comparable mud pit and cellar processes. All but one of the CAU 177 mud pits are post-test pits associated with a borehole (i.e., cellar) and thus, construction and drilling procedures were similar. The only variations between the post-test mud pits and the one 
disposal-type mud pit (CAS 09-09-41) is that the latter is larger in size and is not associated with a borehole.

Mud pit dimensions are listed in Table B.2-5; however, only the depth of the mud pit is of interest because it is an indicator of the depth at which mud would be expected to be encountered if the mud pit is backfilled. Residual drilling mud is expected to be present in all mud pits, but the amount remaining may vary. Soil that was excavated during construction of a mud pit was typically used to form earthen berms that surround the pit and act as a protective barrier.

The cellar dimensions reported in Table B.2-5 include the typical cellar diameter and its depth bgs based on visual observations from open cellars. The cellar cavities are expected to have been excavated to a depth of 10 to $12 \mathrm{ft}$ bgs, which is an indicator of the depth at which potentially impacted soil would be encountered if the cellar is backfilled. The cellars are lined with at least 10 to $12 \mathrm{ft}$ of corrugated metal casing that is typically $10 \mathrm{ft}$ in diameter and is set in a 14-by-14-by-1-ft concrete foundation at the ground surface. Soil is observed at the base of the open cellars of CAU 177; however, it has been documented in previous cellar investigations that a concrete floor may be beneath this layer of soil (NNSA/NSO, 2003a and b).

Common to most CASs of CAU 177 is that they are located within posted radiological areas. With the exception of CASs 09-09-41 and 09-09-45, which are located in the larger RMA in Area 9, all other CASs were posted as Underground RMAs by the BN RadCon organization (Table B.2-5). Since originally posted, CASs 19-23-02 and 20-23-07 have had Underground RMA postings removed, but the reason is uncertain. It is speculated that Underground RMAs were fenced and posted based on process knowledge that the mud pits and cellars were associated with the post-test borehole that extended into the underground area potentially affected by the associated nuclear test (Table B.2-5). The rationale for posting the area may have been that the borehole allowed for a pathway to media that was potentially radioactive. The fences and postings that delineate existing Underground RMAs are the responsibility of the BN RadCon organization and not the NNSA/NSO Environmental Restoration Project.

The boreholes within the cellars are under the control of the BN Borehole Management Program and are not included in the scope of the CAS. The current primary objective of this program is to plug and abandon NTS legacy boreholes for which there is no future use. The boreholes associated with six 
Table B.2-5

\section{Physical Setting of CAU 177 Corrective Action Sites}

\begin{tabular}{|c|c|c|c|c|c|c|c|c|c|c|c|c|}
\hline CAS & 08-23-01 & $09-23-05$ & $09-23-08$ & 09-23-09 & $10-23-02$ & $10-23-03$ & $19-23-01$ & $19-23-03$ & $09-09-41$ & $09-09-45$ & $19-23-02$ & $20-23-07$ \\
\hline Mud Pit & $\mathrm{O}$ & BF & BF & --- & $\mathrm{O}$ & $\mathrm{O}$ & BF & --- & $\mathrm{O}$ & $\mathrm{O}$ & --- & --- \\
\hline Cellar & BF & BF & BF & BF & $\mathrm{BF}(2)$ & $\mathrm{BF}$ & BF & $\mathrm{O}$ & --- & $\mathrm{BF}$ & BF & $\mathrm{O}$ \\
\hline $\begin{array}{c}\text { Mud Pit } \\
\text { Dimensions ( } \mathrm{ft} \text { ) }\end{array}$ & $100 \times 40 \times 6$ & $45 \times 43$ & $65 \times 35$ & N/A & $41 \times 21 \times 5$ & $42 \times 17 \times 5$ & $90 \times 30$ & $\mathrm{~N} / \mathrm{A}$ & $100 \times 50 \times 12$ & $80 \times 25 \times 4$ & N/A & N/A \\
\hline $\begin{array}{l}\text { Cellar Dimensions } \\
\text { (ft) }\end{array}$ & \multicolumn{12}{|c|}{ 10 ft in diameter, 10-12 ft deep } \\
\hline RAD Postings & \multicolumn{8}{|c|}{ Underground RMA } & \multicolumn{2}{|c|}{ RMA } & \multicolumn{2}{|c|}{ Postings Removed } \\
\hline Fence & $\sqrt{ }$ & $\sqrt{ }$ & $\sqrt{ }$ & $\sqrt{ }$ & $\sqrt{ }$ & $\sqrt{ }$ & $\sqrt{ }$ & $\sqrt{ }$ & & & & $\sqrt{ }$ \\
\hline Associated Test & $\begin{array}{c}\text { Cyathus } \\
1970\end{array}$ & $\begin{array}{c}\text { Cathay } \\
1971\end{array}$ & $\begin{array}{c}\text { Haplopappus } \\
1972\end{array}$ & $\begin{array}{c}\text { Hod-B (Red) } \\
1970\end{array}$ & $\begin{array}{c}\text { Tun-C,D } \\
1969\end{array}$ & $\begin{array}{c}\text { Tun-A } \\
1969\end{array}$ & $\begin{array}{l}\text { Panir } \\
1978\end{array}$ & $\begin{array}{l}\text { Tierra } \\
1984\end{array}$ & N/A & $\begin{array}{c}\text { Biggin } \\
1969\end{array}$ & $\begin{array}{c}\text { Amarillo } \\
1989\end{array}$ & $\begin{array}{c}\text { Bullion } \\
1990\end{array}$ \\
\hline Test Release & & & & & $\sqrt{ }$ & $\sqrt{ }$ & & $\sqrt{ }$ & N/A & & & \\
\hline
\end{tabular}

\begin{tabular}{|c|c|c|}
\hline \multicolumn{2}{|c|}{$\begin{aligned} \mathrm{O} & =\text { Open } \\
\mathrm{BF} & =\text { Backfilled } \\
--- & =\text { No feature with this CAS } \\
\mathrm{ft} & =\text { Foot }\end{aligned}$} & $\begin{array}{l}\text { N/A = Not applicable } \\
\text { RMA = Radioactive Mate } \\
\text { Test Release = Either a }\end{array}$ \\
\hline Backfilled MPs & $=3$ & Backfilled Cellars $=10$ \\
\hline Open MPs & $=5$ & Open Cellars $\quad=2$ \\
\hline Total & $=8$ & $=12$ \\
\hline
\end{tabular}


CASs (08-23-01, 09-09-45, 09-23-08, 09-23-09, 19-23-01, and 19-23-02) in CAU 177 have already been plugged. The boreholes associated with four CASs (09-23-05, 10-23-02, 10-23-03, and 19-23-03) are currently on the list of plugback candidates. One of two boreholes associated with CAS 10-23-02 and the borehole associated with CAS 20-23-07 are not currently scheduled for plugback activities.

The amount of infiltration at any specific NTS mud pit is expected to be minimal based on the physical properties of bentonite as well as the low precipitation and high evapotranspiration rates common at the NTS. 


\section{B.2.2.5 Migration Pathways And Transport Mechanisms}

An important element of the CSM is the expected fate and transport of contaminants (i.e., how contaminants migrate through media and where they can be expected in the environment). Fate and transport of contaminants are presented in the CSM as the migration pathways and transport mechanism that could potentially move the contaminants vertically and laterally throughout the various media. The pathways include air, surface water, and groundwater, and are the routes through which possible contamination could migrate from the site(s) to locations where a receptor might receive an exposure. Fate and transport are influenced by physical and chemical characteristics of the contaminants and media described in Sections B.2.2.3 and B.2.2.4. Given the characteristics of both the contaminants and the bentonite drilling mud, contaminant migration is expected to be limited.

Infiltration and percolation of precipitation serves as a driving force for the downward vertical migration of contaminants through the mud or underlying soil in the mud pits and cellars. The annual potential evapotranspiration at the Area 5 Radiological Waste Management Site has been estimated at 62.6 in. (Shott et al., 1997), but the precipitation for this region is between 3.5 and 6 in. per year (Winograd and Thordarson, 1975). Therefore, percolation of infiltrated precipitation at the NTS does not provide a significant mechanism for vertical migration of contaminants to groundwater (DOE/NV, 1992; NNSA/NSO, 2004). Cover material, depending on its thickness, for backfilled mud pits and cellars could significantly diminish infiltration and percolation of precipitation as a driving force for vertical migration of contaminants in the affected media. Also, if present, the concrete floor of a cellar would limit infiltration.

Lateral migration of contaminants through impacted media is expected to be limited to within the physical boundaries of the mud pits and cellars, identified as the walls/berms and metal casing, respectively. Lateral migration may occur as a result of overland flow or erosion and is dependent on the integrity of the mud pit berms and the depth to the base of the excavated cellar. Without a breach in the berm or a large rainfall event that would cause overtopping of the berm, lateral migration through media contained in or surrounding mud pits is expected to be insignificant. Similarly, without a large rainfall event that would cause the cellar cavity to fill with water and overflow, lateral migration through media contained in or surrounding cellars is not expected. Lateral migration of contaminants through the soil from beneath the cellar casing (i.e., 10 to $12 \mathrm{ft}$ bgs) is possible; however, vertical migration would dominate due to infiltration of precipitation through the soil. Also, 
where applicable, the process of backfilling mud pits and cellars following the completion of drilling activities, or plugback activities, would further limit the potential of lateral migration due to lack of a driving force.

Releases to the air may result from resuspension of contaminated surface soil particles with wind movement, or evaporation of the volatile components of TPH in regards to the cellars. Wind could potentially suspend surface soil particles and carry them beyond the boundaries of the mud pits and cellars. However, the mud pits were typically constructed by excavating native soils and creating a protective berm that surrounds the mud pits and reduces the potential for wind to disturb the mud pit surface. Similarly, the soil at the base of open cellars is protected by the metal casing located approximately 10 to $12 \mathrm{ft}$ bgs and, therefore, reduces the potential for wind disturbance. In regards to the open cellars, given the fact that they have been weathered for many years, it is highly unlikely that evaporation of TPH components is a significant migration pathway. A release of contaminants to the air is not considered an active transport mechanism for mud pits and cellars that have been backfilled because the overlying fill would prevent the resuspension of impacted media. Overall, airborne migration of contaminants is considered a minor transport mechanism for CAU 177.

\section{B.2.2.6 Exposure Scenarios}

Human receptors may be exposed to COPCs through oral ingestion, inhalation, or dermal contact (absorption) of drilling mud, soil, or debris due to inadvertent disturbance of these materials, or through irradiation by radioactive materials. The exposure of workers and visitors to site contaminants is very dependent upon the activites of the exposed individual at the site. Based on the future land use as identified in the Nevada Test Site Resource Management Plan (DOE/NV, 1998b), the areas in which all CAU 177 CASs are located are restricted to industrial uses.

The appropriate exposure scenarios for all CAU 177 CASs is the Occasional Use Area, due to each site being in a remote area with no active improvements and the future land use designation is for outdoor tests and/or military training exercises. There is still the possibility, however, that site workers could occupy these locations on an occasional and temporary basis such as a military exercise (NNSA/NSO, 2006). Investigation decisions will be based on the future land-use and exposure scenarios for CAU 177 that are provided in Table B.2-6. 
Table B.2-6

Future Land-Use and Exposure Scenarios

\begin{tabular}{|c|c|c|}
\hline $\begin{array}{l}\text { Corrective } \\
\text { Action Sites }\end{array}$ & Future Land-Use Zone & Exposure Scenario \\
\hline All CASs & $\begin{array}{l}\text { Nuclear and High Explosives Test } \\
\text { This area is designated within the } \\
\text { Nuclear Test Zone for additional } \\
\text { underground nuclear weapons tests } \\
\text { and outdoor high-explosive tests. This } \\
\text { zone includes compatible defense and } \\
\text { nondefense research, development, } \\
\text { and testing activities }\end{array}$ & $\begin{array}{l}\text { Occasional Use Area } \\
\text { This exposure scenario assumes exposure to industrial } \\
\text { workers who are not assigned to the area as a regular } \\
\text { worksite but may occasionally use the site for intermittent } \\
\text { or short-term activities. } \\
\text { A site worker under this scenario is assumed to be on the } \\
\text { site for } 8 \text { hours per day, } 10 \text { days per year, for } 5 \text { years. }\end{array}$ \\
\hline
\end{tabular}

Source: DOE/NV, 1998b; NNSA/NSO, 2006 


\section{B.3.0 Step 2 - Identify the Decisions}

Step 2 of the DQO process identifies the decision statements and defines appropriate alternative actions that may be taken, depending on the answer to the decision statements.

\section{B.3.1 Decision Statements}

The Decision I statement is: "Is any COC present in environmental media within a mud pit or cellar?” For judgmental sampling design, any analytical result for a COPC above the FAL will result in that COPC being designated as a COC. For a probabilistic sampling design, any COPC that has a 95 percent UCL of the average concentration exceeding the FAL will result in that COPC being designated as a COC. If a COC is detected, then Decision II must be resolved.

The Decision II statement is: "If a COC is present, is sufficient information available to meet closure objectives?” Sufficient information is defined to include:

- Identifying the volume of media containing any COC, as bounded by analytical sample results in lateral and vertical directions

- The information needed to characterize IDW for disposal

- The information needed to determine potential remediation waste types

- The information needed to evaluate the feasibility of potential closure options

If sufficient information is not available to meet closure objectives then site conditions will be re-evaluated and additional samples will be collected (as long as the scope of the investigation is not exceeded and any CSM assumption has not been shown to be incorrect).

\section{B.3.2 Alternative Actions to the Decisions}

In this section, the actions that may be taken to solve the problem statement are identified depending on the possible outcomes of the investigation. 


\section{B.3.2.1 Alternative Actions to Decision I}

If no COC associated with a release from the CAS is detected, then mud pit and/or cellar will be closed via the NFA alternative. If a COC associated with a release from the CAS is detected, then the extent of COC contamination will be determined and additional information required to confirm that closure objectives were met will be collected.

\section{B.3.2.2 Alternative Actions to Decision II}

If sufficient information is available to define the extent of COC contamination then a closure strategy of closure in place with administrative controls will be implemented and further assessment of the CAS is not required. If sufficient information is not available to define the extent of COC contamination and confirm that closure objectives were met, then additional samples will be collected. 


\section{B.4.0 Step 3 - Identify the Inputs to the Decision}

This step identifies the information needed, determines sources for information, and identifies sampling and analysis methods that will allow reliable comparisons of analytical results with FALs.

\section{B.4.1 Information Needs}

To resolve Decision I (determine whether a COC is present at a given CAS), samples need to be collected and analyzed following these two criteria: (1) samples must either (a) be collected in areas most likely to contain a COC (judgmental sampling) or (b) properly represent contamination at the CAS (probabilistic sampling); and (2) the analytical suite selected must be sufficient to identify any COCs present in the samples.

To resolve Decision II (determine whether sufficient information is available to meet closure objectives at each CAS), samples need to be collected and analyzed to meet the following criteria:

- Samples must be collected in areas contiguous to the contamination but where contaminant concentrations are below FALs.

- Samples of the waste or environmental media must provide sufficient information to characterize the IDW for disposal.

- The analytical suites selected must be sufficient to detect contaminants at concentrations equal to or less than their corresponding FALs.

\section{B.4.2 Sources of Information}

Information to satisfy Decision I and Decision II will be generated by collecting environmental samples using grab sampling, backhoe excavation, drilling, or other appropriate sampling methods. These samples will be submitted to analytical laboratories meeting the quality criteria stipulated in the Industrial Sites QAPP (NNSA/NV, 2002). Only validated data from analytical laboratories will be used to support DQO decisions. Sample collection and handling activities will follow standard procedures. 


\section{B.4.2.1 Sample Locations}

Design of the sampling approaches for the CAU 177 CASs must ensure that the data collected are sufficient for supporting the selection of the corrective action alternatives (EPA, 2002). To meet this objective, the samples collected from each site should either be from locations that (1) most likely contain a COC, if present (judgmental), or (2) properly represent any contamination that is present within the CAS (probabilistic).

A judgmental sampling approach will be implemented for all cellars and for mud pits if unexpected biasing factors are identified. Biasing factors (including FSRs) will be used to select the most appropriate samples from a particular location for submittal to the analytical laboratory. Biasing factors to be used for selection of sampling locations are listed in Section B.4.2.1.1. Sample locations may be modified based on site conditions, obvious debris or staining of soils, FSRs, or professional judgment if the modified locations meet the DQO decision needs and criteria stipulated. As biasing factors are identified and used for selection of sampling locations, they will be recorded in the appropriate field documents.

A probabilistic sampling approach will be implemented for the mud pits. Sample locations at mud pits are specified by the process presented in Appendix C, which reviews the methodology and computational approach for probabilistic sampling and lists the sample size and locations as calculated by the VSP software program (PNNL, 2005).

The implementation of the judgmental and probabilistic sampling approaches for CAU 177 are summarized in the following sections.

\section{B.4.2.1.1 Judgmental Approach for Sample Location Selection}

Decision I sample locations at cellars and where applicable at mud pits, will be determined based upon the likelihood of the soil containing a COC, if present. These locations will be selected based on field-screening techniques, biasing factors, the CSM, and existing information. Analytical suites for Decision I samples will include all COPCs identified in Tables B.2-3 and B.2-4.

Field-screening techniques may be used to select appropriate sampling locations by providing semi-quantitative data that can be used to comparatively select samples to be submitted for laboratory 
analyses from several screening locations. Field screening may also be used for health and safety monitoring and to assist in making certain health and safety decisions. The following field-screening methods may be used to select analytical samples at CAU 177:

- Walkover surface area radiological surveys - a vehicle-mounted or handheld radiological survey instrument over approximately 100 percent of the CAS boundaries, as permitted by terrain and field conditions to detect hot spots of radiological contamination.

- Alpha and Beta/Gamma Radiation - a handheld radiological survey instrument, or equivalent instrument or method, may be used at these CASs.

- Gamma-Emitting Radionuclides - a handheld dose rate instrument.

Biasing factors may also be used to select samples to be submitted for laboratory analyses based on existing site information and site conditions discovered during the investigation. The following biasing factors will be considered in selecting locations for analytical samples at CAU 177:

- Documented process knowledge on source and location of release.

- Stains: Any spot or area on the soil surface that may indicate the presence of a potentially hazardous liquid release. Typically, stains indicate an organic liquid such as an oil has reached the soil, and may have spread out vertically and horizontally.

- Elevated radiation: Any location identified during radiological surveys that had alpha/beta/gamma levels significantly higher than surrounding background soil.

- Geophysical anomalies: Any location identified during geophysical surveys that had results indicating subsurface materials exist and are not consistent with the natural surroundings or process knowledge (e.g., buried concrete or metal, surface metallic objects).

- Drums, containers, equipment or debris: Materials of interest that may have been used at, or added to, a location, and that may have contained or come in contact with hazardous or radioactive substances at some point during their use.

- Lithology: Locations where variations in lithology (soil or rock) indicate that different conditions or materials exist.

- Preselected areas based on process knowledge of the site: Locations for which evidence such as historical photographs, experience from previous investigations, or interviewee's input exists that a release of hazardous or radioactive substances may have occurred. 
- Preselected areas based on process knowledge of the contaminant(s): Locations that may reasonably have received contamination, selected on the basis of the chemical and/or physical properties of the suspected contaminant(s) in that environmental setting.

- Previous sample results: Locations that may reasonably have been contaminated based upon the results of previous field investigations.

- Other biasing factors: Factors not previously defined for the investigation, but become evident once the investigation of the site is under way.

Decision II sample step-out locations will be selected based on the CSM, biasing factors, and existing data. Analytical suites will include those parameters that exceeded FALs (i.e., COCs) in prior samples. Biasing factors to support Decision II sample locations include Decision I biasing factors plus available analytical results.

\section{B.4.2.1.2 Probabilistic Approach for Sample Location Selection}

Decision I sample locations at mud pits will be selected using a probabilistic approach. Several parameters must be agreed to by the decision makers before estimating the required number of samples to be collected and the locations to be sampled. These parameters include:

- The form of the probability-based sampling design (e.g., simple random vs. systematic/grid)

- A confidence level that a Type I error (false negative) will not occur

- A confidence level that a Type II error (false positive) will not occur

- The width of the "Gray Region" (the range of values below the action level for which it cannot be determined that a COC does not exist at the site)

- An estimated sampling standard deviation (e.g., professional judgment of the expected standard deviation of the sample results) (PNNL, 2005)

- Estimations, if any, for the distribution of the data (e.g., normal, lognormal or gamma)

By consensus of the DQO meeting participants and agreed to by the decision makers, the values in Table B.4-1 were established for the probabilistic sampling.

For analytical non-detections (non-detects), a proxy method of using one-half the actual detection limit values will be followed (EPA, 2004). 
Table B.4-1

Parameter Values Established by DQO Participants

\begin{tabular}{|c|c|c|c|}
\hline Parameter & Description & $\begin{array}{l}\text { DQO Decision for } \\
\text { Estimating } \\
\text { Sample Size }\end{array}$ & $\begin{array}{l}\text { May Change, or Be } \\
\text { Recalculated, Based } \\
\text { on Actual Data? }\end{array}$ \\
\hline $\begin{array}{l}\text { Sampling design } \\
\text { type }\end{array}$ & $\begin{array}{l}\text { Probabilistic sampling approaches include } \\
\text { Simple Random, Stratified, Systematic and } \\
\text { Grid, Ranked Set, Adaptive Cluster, and } \\
\text { Composite }\end{array}$ & $\begin{array}{l}\text { Employ a systematic } \\
\text { random design. }\end{array}$ & $\begin{array}{l}\text { No, unless decision is } \\
\text { made to use data } \\
\text { collected to stratify the } \\
\text { site. }\end{array}$ \\
\hline $\begin{array}{l}\text { False negative } \\
\text { error }\end{array}$ & $\begin{array}{l}\text { Error generated from deciding that a COC is } \\
\text { not present when it actually is. }\end{array}$ & $\begin{array}{l}\text { UCL established at } \\
95 \text { percent. }\end{array}$ & No \\
\hline $\begin{array}{l}\text { False positive } \\
\quad \text { error }\end{array}$ & $\begin{array}{l}\text { Error generated from deciding that a COC is } \\
\text { present when it actually is not. }\end{array}$ & Established at $80 \%$. & No \\
\hline Gray region width & $\begin{array}{l}\text { Region of a Decision Performance Goal } \\
\text { Diagram where the sample data tend toward } \\
\text { rejecting the baseline condition, but the } \\
\text { evidence (data statistics) is not sufficient to be } \\
\text { overwhelming. Wider gray regions yield } \\
\text { smaller sample sizes. Determined with } \\
\text { professional judgment and cost/benefit } \\
\text { evaluation. }\end{array}$ & $\begin{array}{l}\text { Initially established to } \\
\text { be one-half the } \\
\text { action level. }\end{array}$ & $\begin{array}{l}\text { No, unless decision is } \\
\text { made to use data } \\
\text { collected to stratify the } \\
\text { site. Gray region used } \\
\text { for sampling design } \\
\text { purposes only. }\end{array}$ \\
\hline Action level & $\begin{array}{l}\text { For sampling design purposes, the action } \\
\text { level is the numerical value which when } \\
\text { exceeded declares the site to be } \\
\text { contaminated. }\end{array}$ & $\begin{array}{l}\text { Established to be } \\
2 \text { times the mean } \\
\text { (average) of the } \\
\text { background } \\
\text { radiological readings } \\
\text { at each site } \\
\text { (Appendix C). }\end{array}$ & $\begin{array}{l}\text { Final action levels for } \\
\text { cOCs are used during } \\
\text { this determination. }\end{array}$ \\
\hline $\begin{array}{l}\text { Estimated } \\
\text { variability }\end{array}$ & $\begin{array}{l}\text { Estimate of standard deviation expected from } \\
\text { the set of samples collected. Value for the } \\
\text { standard deviation impacts the minimum } \\
\text { required sample size. }\end{array}$ & $\begin{array}{l}\text { Established to be the } \\
\text { variability of data } \\
\text { from site radiological } \\
\text { surveys. }\end{array}$ & $\begin{array}{l}\text { Yes, variability will be } \\
\text { calculated and, if } \\
\text { necessary, additional } \\
\text { samples will be collected. }\end{array}$ \\
\hline Data distribution & $\begin{array}{l}\text { Distribution of the actual data typically follows } \\
\text { a pattern, such as a bell-shaped curve, a } \\
\text { log-normal curve, or skewed towards one } \\
\text { direction, such as a gamma distribution. } \\
\text { Distribution of actual data impacts the } \\
\text { determination of the } 95 \text { percent upper } \\
\text { confidence limit. }\end{array}$ & $\begin{array}{l}\text { Use non-parametric } \\
\text { statistical tests. }\end{array}$ & $\begin{array}{l}\text { Yes, use best-fit } \\
\text { distributions. }\end{array}$ \\
\hline
\end{tabular}

Source: Summary of DQO meeting for CAU 177; EPA, 2000a and c; PNNL 2005

$\mathrm{COC}=$ Contaminant of concern

COPC = Contaminant of potential concern

$\mathrm{DQO}=$ Data quality objective
EPA = U.S. Environmental Protection Agency $\mathrm{VSP}=$ Visual Sample Plan 
Individual mud pit probabilistic sampling and analysis designs are discussed in Section B.8.0. Appendix C provides the methodology and computational approach for probabilistic sampling, and lists the sample size and locations as calculated by the VSP software program (PNNL, 2005).

\section{B.4.2.2 Analytical Methods}

Analytical methods are available to provide the data needed to resolve the decision statements. The analytical methods and laboratory requirements (e.g., detection limits, precision, and accuracy) are specified in Sections 7.2.1 and 7.2.2 of this document. Table B.4-2 lists the analytes reported by the various analytical methods that are considered to be COPCs. 
Table B.4-2

Analytes Reported by Analytical Methods

\begin{tabular}{|c|c|c|c|c|c|c|}
\hline \multicolumn{2}{|c|}{ VOC } & SVOC & TPH & PCB & Metals & Radionuclides \\
\hline $\begin{array}{c}\text { 1,1,1-Trichloroethane } \\
\text { 1,1,1,2-Tetrachloroethane } \\
\text { 1,1,2,2-Tetrachloroethane } \\
\text { 1,1,2-Trichloroethane } \\
\text { 1,1-Dichloroethane } \\
\text { 1,1-Dichloroethene } \\
\text { cis-1,2-Dichloroethene } \\
\text { 1,2-Dichloroethane } \\
\text { 1,2-Dichloropropane } \\
\text { 1,2,4--Trichlorobenzene } \\
\text { 1,2,4-Trimethylbenzene } \\
\text { 1,2-Dibromo-3-chloropropane } \\
\text { 1,3,5-Trimethylbenzene } \\
\text { 1,4-Dioxane } \\
\text { 2-Butanone } \\
\text { 2-Chlorotoluene } \\
\text { 2-Hexanone } \\
\text { 4-Methyl-2-pentanone } \\
\text { Acetone } \\
\text { Acetonitrile } \\
\text { Allyl chloride } \\
\text { Benzene } \\
\text { Bromodichloromethane } \\
\text { Bromoform } \\
\text { Bromomethane } \\
\text { Carbon disulfide } \\
\text { Carbon tetrachloride } \\
\text { Chlorobenzene } \\
\text { Chloroethane } \\
\text { Chloroform } \\
\text { Chloromethane } \\
\text { Chloroprene } \\
\text { Dibromochloromethane } \\
\text { Dichlorodifluoromethane } \\
\text { Ethyl methacrylate } \\
\text { Ethyllbenzene } \\
\text { Isobutyl alcohol } \\
\text { Isopropylbenzene } \\
\text { m-Dichlorobenzene (1,3) } \\
\text { Methacrylonitrile } \\
\text { Methyl methacrylate }\end{array}$ & $\begin{array}{c}\text { Methylene chloride } \\
\text { N-Butylbenzene } \\
\text { N-Propylbenzene } \\
\text { o-Dichlorobenzene }(1,2) \\
\text { p-Dichlorobenzene }(1,4) \\
\text { p-isopropyltoluene } \\
\text { sec-Butylbenzene } \\
\text { Styrene } \\
\text { tert--Butylbenzene } \\
\text { Tetrachloroethene } \\
\text { Toluene } \\
\text { Total Xylenes } \\
\text { Trichloroethene } \\
\text { Trichlorofluoromethane } \\
\text { Vinyl acetate } \\
\text { Vinyl chloride }\end{array}$ & $\begin{array}{c}\text { 2,3,4,6-Tetrachlorophenol } \\
\text { 2,4-Dimethylphenol } \\
\text { 2,4-Dinitrotoluene } \\
\text { 2,4,5-Trichlorophenol } \\
\text { 2,4,6-Trichlorophenol } \\
\text { 2-Chlorophenol } \\
\text { 2-Methylnaphthalene } \\
\text { 2-Methylphenol } \\
\text { 2-Nitrophenol } \\
\text { 3-Methylphenol } \\
\text { 4-Chloroaniline } \\
\text { 4-Methylphenol } \\
\text { 4-Nitrophenol } \\
\text { Acenaphthene } \\
\text { Acenaphthylene } \\
\text { Aniline } \\
\text { Anthracene } \\
\text { Benzo(a)anthracene } \\
\text { Benzo(a)pyrene } \\
\text { Benzo(b)fluoranthene } \\
\text { Benzo(g,h,i)perylene } \\
\text { Benzo(k)fluoranthene } \\
\text { Benzoic Acid } \\
\text { Benzyl Alcohol } \\
\text { Bis(2-ethylhexyl) phthalate } \\
\text { Butyl benzyl phthalate } \\
\text { Carbazole } \\
\text { Chrysene } \\
\text { Dibenzo(a,h)anthracene } \\
\text { Dibenzofuran } \\
\text { Diethyl Phthalate } \\
\text { Dimethyl Phthalate } \\
\text { Di-n-butyl Phthalate } \\
\text { Di-n-octyl Phthalate } \\
\text { Fluoranthene } \\
\text { Fluorene } \\
\text { Hexachlorobenzene } \\
\text { Hexachlorobutadiene } \\
\text { Hexachloroethane } \\
\text { Indeno(1,2,3-cd)pyrene } \\
\text { Naphthalenea } \\
\text { Nitrobenzene } \\
\text { N-Nitroso-di-n-propylamine } \\
\text { Pentachlorophenol } \\
\text { Phenanthrene } \\
\text { Phenol } \\
\text { Pyrene } \\
\text { Pyridine } \\
\text { and }\end{array}$ & $\begin{array}{c}\text { TPH } \\
\text { (Diesel-Range Organics } \\
\text { and } \\
\text { Gasoline-Range Organics) }\end{array}$ & $\begin{array}{l}\text { Aroclor } 1060 \\
\text { Aroclor } 1221 \\
\text { Aroclor } 1232 \\
\text { Aroclor } 1242 \\
\text { Aroclor } 1248 \\
\text { Aroclor } 1254 \\
\text { Aroclor } 1260 \\
\text { Aroclor } 1268\end{array}$ & $\begin{array}{c}\text { Arsenic } \\
\text { Barium } \\
\text { Beryllium } \\
\text { Cadmium } \\
\text { Chromium } \\
\text { Lead } \\
\text { Mercury } \\
\text { Selenium } \\
\text { Silver }\end{array}$ & $\begin{array}{c}\text { Plutonium-238 } \\
\text { Plutonium-239/240 } \\
\text { Strontium-90 } \\
\text { Uranium-234 } \\
\text { Uranium-235 } \\
\text { Uranium-238 } \\
\text { Other parameters: } \\
\text { } \\
\text { Gamma-emitting radionuclides } \\
\text { including: } \\
\text { Actinium-228 } \\
\text { Aluminum-26 } \\
\text { Americium-241 } \\
\text { Antimony-125 } \\
\text { Beryllium-7 } \\
\text { Bismuth-212 } \\
\text { Bismuth-214 } \\
\text { Cesium-134 } \\
\text { Cesium-137 } \\
\text { Cobalt-58 } \\
\text { Cobalt-60 } \\
\text { Curium-243 } \\
\text { Europium-152 } \\
\text { Europium-154 } \\
\text { Europium-155 } \\
\text { Lead-212 } \\
\text { Lead-214 } \\
\text { Niobium-94 } \\
\text { Potassium-40 } \\
\text { Thallium-208 } \\
\text { Thorium-227 } \\
\text { Thorium-234 } \\
\text { Uranium-235 }\end{array}$ \\
\hline
\end{tabular}




\section{B.5.0 Step 4 - Define the Boundaries of the Study}

The purpose of this step is to define the population of interest, define the spatial boundaries, determine practical constraints on data collection, and define the scale of decision making.

\section{B.5.1 Populations of Interest}

The population of interest to resolve Decision I ("Is any COC present in environmental media within a mud pit or cellar?”) is either (a) any location within the site that is contaminated with any contaminant above a FAL (judgmental sampling) or (b) locations representative of site contamination (probabilistic sampling). The populations of interest to resolve Decision II ("If a COC is present, is sufficient information available to meet closure objectives?”) are:

- Each one of a set of locations bounding contamination in lateral and vertical directions

- Investigation-derived waste or environmental media that must be characterized for disposal

- Potential remediation waste

- Environmental media where natural attenuation or biodegradation or construction/evaluation of barriers is considered

Regardless of the sampling design, the population of interest for this investigation is surface soil defined as either (a) the residual drilling fluid contained in a mud pit or (b) potentially impacted soil at the base of a cellar. For uncovered mud pits and cellars, the surface soil is defined as 0 to 12 in. in depth. For backfilled mud pits and cellars, the soil to be sampled resides within the first 12 in. directly below the fill material.

Following the approved risk-based approach, soil samples from the surface of the residual drilling fluid are considered sufficient to adequately characterize the risk posed by the mud pits. A review of data from previous mud pit investigations conducted under the complex process has demonstrated that TPH-DRO concentrations in surface soils are representative of the TPH-DRO concentrations throughout the depth of the residual drilling fluid (NNSA/NSO, 2004). The same process would apply to radiological constituents suspected to be present in the residual drilling fluid in the mud pits of CAU 177. In addition, considering the proposed industrial future land uses, the surface soil is the 
primary exposure point for future workers. Thus, samples collected from subsurface soils would yield no additional information.

\section{B.5.2 Spatial Boundaries}

Spatial boundaries are the maximum lateral and vertical extent of expected contamination at each mud pit and cellar, as shown in Table B.5-1. Contamination found beyond these boundaries may indicate a flaw in the CSM and may require re-evaluation of the CSM before the investigation could continue. Each CAS is considered geographically independent and intrusive activities are not intended to extend into the boundaries of neighboring CASs.

Table B.5-1

Spatial Boundaries of CAU 177 Mud Pits and Cellars

\begin{tabular}{|c|l|}
\hline \multicolumn{1}{|c|}{ Feature } & \multicolumn{1}{c|}{ Spatial Boundaries } \\
\hline \hline Mud Pit & $\begin{array}{l}\text { The lateral boundaries are the walls/berms of each mud pit plus a } \\
50-f t \text { lateral buffer. The vertical boundary is the depth of residual } \\
\text { drilling mud in the mud pit, typically 1-3 } \mathrm{ft} .\end{array}$ \\
\hline Cellar & $\begin{array}{l}\text { The lateral boundary is the corrugated metal casing that lines } \\
\text { each cellar, typically } 10 \mathrm{ft} \text { in diameter. The vertical boundary is } \\
\text { defined as } 15 \text { below the base of the cellar. }\end{array}$ \\
\hline
\end{tabular}

\section{B.5.3 Practical Constraints}

Investigation of these CASs may be impacted by physical constraints and activities at the NTS. General practical constraints include weather, rough terrain, and access restrictions. Access restrictions include scheduling conflicts on the NTS with other entities, areas posted as contamination areas requiring appropriate work controls, areas requiring authorized access, and physical barriers (e.g., fences).

Specific constraints that may cause a temporary delay in sampling include potential restricted access to Area 19 and 20 CASs during winter months due to snow cover; obtaining a confined space permit (if needed) to enter open cellars; restricted access to mud pits and open cellars due to ponding of water following inclement weather; and military exercises, which would restrict access to Area 19 and 20 . 
Identified constraints that can limit intrusive sampling include buried debris, the orientation and presence of drill stemming that remains in the cellar/borehole, a concrete bottom in the cellar, underground utilities, overhead power lines, and underlying geology (i.e., caliche, bedrock). Underground utilities surveys will be conducted at each CAS before starting investigation activities to determine whether utilities exist, and, if so, determining the limit of spatial boundaries for intrusive activities.

\section{B.5.4 Define the Scale of Decision Making}

The scale of decision making for resolving Decision I and Decision II statements is defined as the individual mud pit or cellar. This allows for individual mud pits and cellars within a CAS to be closed independent of one another. For Decision I, any COC detected at any location within a cellar will cause the determination that the media contained by that feature is contaminated and needs further evaluation. Any COC identified in a mud pit will cause the determination that the residual mud is contaminated. Because contamination is expected to be bound within the matrix of the drilling mud, further evaluation is not necessary.

For resolving the Decision II statement, the scale of decision making for a cellar is defined as a contiguous area contaminated with any COC likely originating from the cellar. Resolution of Decision II requires this contiguous area to be bounded laterally and vertically. For mud pits, because contaminants are bound within the matrix of the drilling mud, the maximum lateral extent would be defined as the walls/berms of the mud pit, and the vertical extent would be the depth of the residual drilling mud. 


\section{B.6.0 Step 5 - Develop a Decision Rule}

This step develops a decision rule (“If..., then...”) statement that defines the conditions under which possible alternative actions will be chosen. In this step, we specify the parameters that characterize the population of interest, specify the FALs, confirm that detection limits are sensitive enough to detect FALs, and present decision rules.

\section{B.6.1 Population Parameters}

For judgmental sampling results, the population parameter is the maximum observed concentration of each contaminant from each individual analytical sample. Each sample result will be compared to the FALs to determine the appropriate resolution to Decision I and Decision II. For Decision I, a single sample result for any contaminant exceeding a FAL would cause a determination that a COC is present within the CAS.

For probabilistic sampling results, the population parameter is the 95 percent UCL of the sample population average concentration of each contaminant from all analytical samples from an individual contaminant release. The population parameter will be compared to the corresponding FALs to determine the appropriate resolution to Decision I and Decision II. For Decision I, a 95 percent UCL of the average concentration for any contaminant exceeding a FAL would cause a determination that a COC is present within the CAS.

The Decision II population parameter is an individual analytical result from a bounding sample. For Decision II, a single bounding sample result for any contaminant exceeding a FAL would cause a determination that the contamination is not bounded.

\section{B.6.2 Decision Rules}

The decision rules applicable to both Decision I and Decision II are:

- If COC contamination is inconsistent with the CSM or extends beyond the spatial boundaries identified in Section B.5.2, then work will be suspended and the investigation strategy will be reconsidered. For a cellar, if a COC is present, is consistent with the CSM, and is within spatial boundaries, then the decision will be to continue sampling to define the extent. For a 
mud pit, if the characteristic concentration of a contaminant exceeds the action level, then the mud pit will be considered contaminated and closure alternatives will be evaluated.

The decision rules for Decision I are:

- If the population parameter of any COPC in the Decision I population of interest (defined in Step 4) for a cellar exceeds the corresponding FAL, then that analyte is identified as a COC, and Decision II samples will be collected, if necessary, to define the extent of COC contamination. If the population parameter of any COPC in the Decision I population of interest (defined in Step 4) for a mud pit exceeds the corresponding FAL, then that analyte is identified as a COC, and it will be determined that the residual mud is contaminated and bounded by the Decision I random sampling and the berm of the mud pit. If all COPC concentrations are less than the corresponding action levels in both mud pits and cellars, then the decision will be NFA.

The decision rules for Decision II are:

- If the population parameter (the maximum observed concentration of any COC) in the Decision II population of interest (defined in Step 4) for a cellar exceeds the corresponding FAL, then additional samples will be collected to complete the Decision II evaluation. If all bounding COC concentrations are less than the corresponding FALs, then the decision will be that the extent of contamination has been defined in the corresponding lateral and/or vertical direction.

- If valid analytical results are available for the waste characterization samples defined in Section B.8.0, then the decision will be that sufficient information exists to characterize the IDW for disposal, determine potential remediation waste types, and to confirm that closure objectives were met.

\section{B.6.3 Action Levels}

The PALs presented in this section are to be used for site screening purposes. They are not necessarily intended to be used as cleanup action levels or FALs. However, they are useful in screening out contaminants that are not present in sufficient concentrations to warrant further evaluation and, therefore, streamline the consideration of remedial alternatives. The RBCA process used to establish FALs is described in the Industrial Sites Project Establishment of Final Action Levels (NNSA/NSO, 2006). This process conforms with NAC Section 445A.227, which lists the requirements for sites with soil contamination (NAC, 2005). For the evaluation of corrective actions, NAC Section 445A.22705 requires the use of ASTM Method E1739-95 to “conduct an evaluation of the site, based on the risk it poses to public health and the environment, to determine the necessary 
remediation standards (i.e., FALs) or to establish that corrective action is not necessary” (ASTM, 1995).

This RBCA process defines three tiers (or levels) of evaluation involving increasingly sophisticated analyses:

- Tier 1 evaluation - sample results from source areas (highest concentrations) are compared to action levels based on generic (non-site-specific) conditions (i.e., the PALs established in the SAFER). The FALs may then be established as the Tier 1 action levels, or the FALs may be calculated using a Tier 2 evaluation.

- Tier 2 evaluation - conducted by calculating Tier 2 SSTLs using site-specific information as inputs to the same or similar methodology used to calculate Tier 1 action levels. The Tier 2 SSTLs are then compared to individual sample results from reasonable points of exposure (as opposed to the source areas as is done in Tier 1) on a point-by-point basis. Total TPH concentrations will not be used for risk-based decisions under Tier 2 or Tier 3. Rather, the individual chemicals of concern will be compared to the SSTLS.

- Tier 3 evaluation - conducted by calculating Tier 3 SSTLs on the basis of more sophisticated risk analyses using methodologies described in Method E1739-95 that consider site-, pathway-, and receptor-specific parameters.

The comparison of laboratory results to FALs and the evaluation of potential corrective actions will be included in the investigation report. The FALs will be defined (along with the basis for their definition) in the investigation report.

\section{B.6.4 Measurement and Analysis Sensitivity}

The measurement and analysis methods specified in Sections 7.2.1 and 7.2.2 of this document and in the Industrial Sites QAPP (NNSA/NV, 2002) are capable of measuring analyte concentrations at or below the corresponding FALs for each COPC. See Section 7.2 for additional details. 


\section{B.7.0 Step 6 - Tolerable Limits on Decision Errors}

The purpose of this step is to specify performance criteria for the decision rule. Setting tolerable limits on decision errors requires the planning team to weigh the relative effects of a threat to human health and the environment, expenditure of resources, and consequences of an incorrect decision.

For judgmental sampling designs, Section 7.1 of the EPA QA/G-4HW (EPA, 2000a) guidance states that quantitative statements about data quality will be limited to measurement error. Measurement error is influenced by imperfections in the measurement and analysis system. Random and systematic measurement errors are introduced in the measurement process during physical sample collection, sample handling, sample preparation, sample analysis, and data reduction. If measurement errors are not controlled, they may lead to errors in making the DQO decisions.

Limits on decision errors for probabilistic sampling designs are quantitatively set and measurable. Hypothesis, therefore, can be tested to ascertain whether a site is contaminated, to what degree it is contaminated, and what additional impacts common to contaminated sites might have occurred. The use of a probabilistic design provides the ability to optimize resources while meeting DQOs.

This section provides an assessment of the possible outcomes of DQO decisions and the impact of those outcomes if the decisions are in error.

The baseline condition (i.e., null hypothesis) and alternative condition for Decision I are:

- Baseline condition - A COC is present.

- Alternative condition - A COC is not present.

The baseline condition (i.e., null hypothesis) and alternative condition for Decision II are as follows:

- $\quad$ Baseline condition - The extent of a COC has not been defined.

- Alternative condition - The extent of a COC has been defined.

Decisions and/or criteria have false negative or false positive errors associated with their determination. The impact of these decision errors and the methods that will be used to control these 
errors are discussed in the following subsections. In general terms, confidence in DQO decisions based on judgmental sampling results will be established qualitatively by:

- The development of and concurrence of CSM(s) (based on process knowledge) by stakeholder participants during the DQO process.

- Testing the validity of CSM(s) based on investigation results.

- Evaluating the quality of the data based on DQI parameters.

\section{B.7.1 False Negative Decision Error}

The false negative decision error would mean deciding that a COC is not present when it actually is (Decision I), or deciding that the extent of a COC has been defined when it has not (Decision II). In both cases, the potential consequence is an increased risk to human health and environment.

\section{B.7.1.1 False Negative Decision Error for Judgmental Sampling}

The false negative decision error (where consequences are more severe) for judgmental sampling designs is controlled by meeting these criteria:

1. For Decision I, having a high degree of confidence that the judgmental sample locations selected will identify COCs if present anywhere within the CAS. For Decision II, having a high degree of confidence that the sample locations selected will identify the extent of COCs.

2. Having a high degree of confidence that analyses conducted will be sufficient to detect any COCs present in the samples.

3. Having a high degree of confidence that the dataset is of sufficient quality and completeness.

To satisfy the first criterion, Decision I samples must be collected from areas most likely to be contaminated by COCs (supplemented by random samples where appropriate). Decision II samples must be collected in areas that represent the lateral and vertical extent of contamination (above action levels). The following characteristics must be considered to control decision errors for the first criterion:

- Source and location of release

- Chemical nature and fate properties 
- $\quad$ Physical transport pathways and properties

- Hydrologic drivers

These characteristics were considered during the development of the CSM and the selection of sampling locations. The field-screening methods and biasing factors listed in Section B.4.2.1.1 will be used to further ensure that appropriate sampling locations are selected to meet these criteria. Radiological survey instruments and field-screening equipment will be calibrated and checked in accordance with the manufacturer's instructions and approved procedures. The investigation report will present an assessment on the DQI of representativeness; i.e., that samples were collected from those locations that best represent the populations of interest as defined in Section B.5.1.

To satisfy the second criterion, Decision I samples will be analyzed for the chemical and radiological parameters listed in Section 4.1. Decision II samples will be analyzed for those chemical and radiological parameters that identified unbounded COCs. The DQI of sensitivity will be assessed for all analytical results to ensure that all sample analyses had measurement sensitivities (detection limits) that were less than or equal to the corresponding FALs. If this criterion is not achieved, the affected data will be assessed (for usability and potential impacts on meeting site characterization objectives) in the investigation report.

To satisfy the third criterion, the entire dataset, as well as individual sample results, will be assessed against the DQIs of precision, accuracy, comparability, and completeness as defined in the Industrial Sites QAPP (NNSA/NV, 2002) and in Section 7.2. The DQIs of precision and accuracy will be used to assess overall analytical method performance as well as to assess the need to potentially "flag" (qualify) individual analyte results when corresponding QC sample results are not within the established control limits for precision and accuracy. Data qualified as estimated for reasons of precision or accuracy may be considered to meet the analyte performance criteria based on an assessment of the data. The DQI of completeness will be assessed to ensure that all data needs identified in the DQO have been met. The DQI of comparability will be assessed to ensure that all analytical methods used are equivalent to standard EPA methods so that results will be comparable to regulatory action levels that have been established using those procedures. Strict adherence to established procedures and QA/QC protocol protects against false negatives. 
To provide information for the assessment of the DQIs of precision and accuracy, the following QC samples will be collected as required by the Industrial Sites QAPP (NNSA/NV, 2002):

- Field duplicates (minimum of 1 per matrix per 20 environmental samples)

- Laboratory QC samples (minimum of 1 per matrix per 20 environmental samples or 1 per CAS per matrix, if less than 20 collected)

\section{B.7.1.2 False Negative Decision Error for Probabilistic Sampling}

Control of the false negative decision error under a probabilistic sampling design is quantitatively established through the selection of the false negative error rate (PNNL, 2005). The false negative error rate for all CASs was established by the DQO meeting participants at 0.05 (or 5 percent probability). The false negative error rate is contingent upon:

- Population distribution

- Sample size

- Actual population variability

- Measurement error

Control of the false negative decision error, therefore, for probabilistic sampling designs is accomplished by:

- Determining the appropriate population distribution(s)

- Ensuring a sufficient sample size

- Having a high degree of confidence that analyses conducted will be sufficient to detect any COCs present in samples

\section{B.7.2 False Positive Decision Error}

The false positive decision error would mean deciding that a COC is present when it is not, or a COC is unbounded when it is not, resulting in increased costs for unnecessary sampling and analysis and potentially for unnecessary corrective actions.

False positive results are typically attributed to laboratory and/or sampling/handling errors that could cause cross contamination. To control against cross contamination, decontamination of sampling equipment will be conducted according to established and approved procedures and only clean 
sample containers will be used. To determine whether a false positive analytical result may have occurred, the following QC samples will be collected as required by the IS QAPP (NNSA/NV, 2002):

- Trip blanks (1 per sample cooler containing VOC environmental samples)

- Equipment rinsate blanks (1 per sampling event for each type of decontamination procedure)

- Source blanks (1 per lot of source material that contacts sampled media)

- Field duplicates (1 per 20 environmental samples or 1 per CAS per matrix, if less than 20 collected)

- Field blanks (1 per 20 environmental samples or 1 per day)

- Laboratory QC samples (1 per 20 environmental samples or 1 per CAS per matrix, if less than 20 collected)

For probabilistic sampling, false positive decision error was established by the DQO meeting participants at 0.20 (or 20 percent probability). This decision error will also be controlled by implementing the controls listed in Section B.7.1 for probabilistic sampling designs. 


\section{B.8.0 Step 7 - Optimize the Design for Obtaining Data}

This section provides the general approach for obtaining the information necessary to resolve Decision I and Decision II. Section B.8.1 provides the probabilistic sampling approach that will be implemented to select sample locations and evaluate analytical results at all mud pits. Section B.8.2 provides the judgmental sampling approach that will be implemented to select sample locations and evaluate analytical results at all cellars. Judgmental sampling allows the methodical selection of sample locations that target the populations of interest (defined in Step 4). Even in the absence of biasing factors, the sampling planned is considered judgmental because of the limited spatial boundaries of each cellar. A summary of the sampling approach and data evaluation for each CAS is presented in Table B.8-1.

Table B.8-1

Summary of Sampling Approach and Data Evaluation, CAU 177

\begin{tabular}{|c|c|c|c|}
\hline $\begin{array}{c}\text { Feature with } \\
\text { Applicable CASs }\end{array}$ & Description & Decision I Parameters & Evaluation of Data \\
\hline $\begin{array}{c}\text { Mud Pit } \\
\text { (08-23-01, 09-09-41, } \\
09-09-45,09-23-05 \\
09-23-08,10-23-02 \\
10-23-03,19-23-01)\end{array}$ & $\begin{array}{c}\text { Probabilistic Sampling } \\
\text { Approach }\end{array}$ & $\begin{array}{l}\text {-- Initial \# of locations: } 10 \\
\text { random } \\
\text {-- Soil profile depth(s): } \\
\text { Surface (0-12 in. or first } 12 \text { in. } \\
\text { below cover material if } \\
\text { backfilled) }\end{array}$ & $\begin{array}{l}95 \text { percent UCL of the } \\
\text { mean concentration of } \\
\text { each constituent that } \\
\text { exceeds the PAL will be } \\
\text { compared to the FAL. }\end{array}$ \\
\hline $\begin{array}{c}\text { Cellar } \\
\text { (08-23-01, 09-09-45, } \\
09-23-05,09-23-08, \\
09-23-09,10-23-02 \\
\text { 10-23-03, 19-23-01, } \\
\text { 19-23-02, 19-23-03, } \\
\text { 20-23-07) }\end{array}$ & $\begin{array}{l}\text { Judgmental Sampling } \\
\text { Approach }\end{array}$ & $\begin{array}{l}\text {-- Initial \# of locations: } 2 \\
\text { equally distributed locations } \\
\text {-- Soil profile depth(s): } \\
\text { Surface (0-12 in. or first } 12 \text { in. } \\
\text { below cover material if } \\
\text { backfilled) at biasing factor or } \\
\text { distributed at the accessible } \\
\text { area of the cellar in the } \\
\text { absence of biasing factors. }\end{array}$ & $\begin{array}{c}\text { Point-by-point } \\
\text { comparison of each } \\
\text { analytical result to the } \\
\text { FAL. }\end{array}$ \\
\hline
\end{tabular}

$\mathrm{FAL}=$ Final action level

$\mathrm{PAL}=$ Preliminary action level

$\mathrm{UCL}=$ Upper confidence limit

Statistical methods that generate site characteristics will be used at all mud pits. The information collected from probabilistic sampling will allow for establishing radiological contaminant concentrations that represent the mud pit as a whole. Because individual sample results, rather than an average (mean) concentration, will be used to compare to action levels at the cellars undergoing judgmental sampling, statistical methods to generate site characteristics will not be used. Section 


\subsection{4 of the EPA Data Quality Objectives Process for Hazardous Waste Site Investigations} (EPA QA/G-4HW) (EPA, 2000a) guidance states that the use of statistical methods may not be warranted by program guidelines or site-specific sampling objectives. The need for statistical methods is dependent upon the decisions being made. Section 7.1 of the EPA QA/G-4HW guidance states that a nonprobabilistic (judgmental) sampling design is developed when there is sufficient information on the contamination sources and history to develop a valid CSM and to select specific sampling locations. This design is used to confirm the existence of contamination at specific locations and provide information (such as extent of contamination) about specific areas of the site.

All sample locations will be selected to satisfy the DQI of representativeness in that samples collected from selected locations will best represent the populations of interest as defined in Section B.5.1. To meet this criterion for probabilistic sites, randomly selected sample locations will be chosen, with locations specified by the VSP software as outlined in Section B.4.2.1.2 and Appendix C. If a sample cannot be collected from a particular location or the location is not representative of the site, the location will be replaced by another randomly-determined location. To meet the DQI criterion for judgmentally sampled sites, a biased sampling strategy will be used for Decision I to target areas with the highest potential for contamination, if it is present anywhere in the cellar. Sample locations will be determined based on process knowledge, previously acquired data, or the field screening and biasing factors listed in Section B.4.2.1.1. If biasing factors are present in soils below locations where Decision I samples were removed, additional Decision I soil samples will be collected at depth intervals selected by the SS based on biasing factors to a depth where the biasing factors are no longer present. The SS has the discretion to modify the sample locations at judgmentally sampled CASs, but only if the modified locations meet the decision needs and criteria stipulated in this DQO.

\section{B.8.1 Mud Pit Sampling Design}

The mud pits are being investigated based on the potential for radiological contamination of the residual drilling mud contained within the mud pit. A total of 10 samples per mud pit will be collected from the residual drilling mud, or 0 to $12 \mathrm{in}$. below cover material or at the expected depth of mud for backfilled mud pits. This number has been estimated to sufficiently satisfy the criteria of establishing the 95 percent UCL of the average COPC concentration and to meet the parameter values listed in Table B.4-1. Appendix C reviews the methodology and computational approach of the VSP 
software program for determining the sample size and locations for probabilistic sampling (PNNL, 2005). The samples will be configured in a triangular pattern to ensure that all areas of the pit are represented. The initial sample location will be randomly chosen and will serve as the basis for the triangular grid that is established by VSP. Figure B.8-1 shows the predetermined layout of surface sample locations to be collected at a mud pit.

Samples to be collected at open mud pits will be obtained through hand scoop, backhoe excavation, or other appropriate method. Samples to be collected at backfilled mud pits will be obtained through backhoe excavation or other appropriate method. For backfilled mud pits, the cover material/residual mud interface is expected to be easily recognized and encountered at a depth bgs typical of other NTS excavated mud pits (4 to $5 \mathrm{ft}$ bgs based on observations from previous mud pit investigations). Although the cover material/residual mud interface was well recognized at most previously investigated backfilled mud pits, the transition between these layers may not be distinguishable for reasons such as (a) the mud pit was not used or only partially used and (b) because boundaries of backfilled mud pits are approximated, some unbiased samples may be located in the former mud pit berm. The following, therefore, lists a procedure for obtaining samples from residual mud:

- Soil will be monitored for lithology changes during excavation to identify the cover material/residual mud interface.

- If the interface is recognizable, then a sample will be collected from the first $12 \mathrm{in.}$ of mud/cuttings directly below the interface.

- If the interface is not recognizable, then a sample will be collected at the depth where the residual mud is expected to be located based on the observations from other mud pits.

- If the interface has not been identified and a layer of caliche is encountered, then a sample will be collected directly above the caliche.

In addition to the 10 unbiased samples to be collected from each mud pit, additional biased samples may be collected in areas of obvious spills or staining located either within or adjacent to the mud pit. The SS has the discretion to modify the sample locations or order additional biased samples to be collected, but only if the new locations meet the decision needs and criteria stipulated in this DQO. The SS will use professional judgment to determine whether biasing factors (e.g., stains, elevated screening levels) are found during Decision I sampling that might indicate the need to take subsurface Decision II samples. 


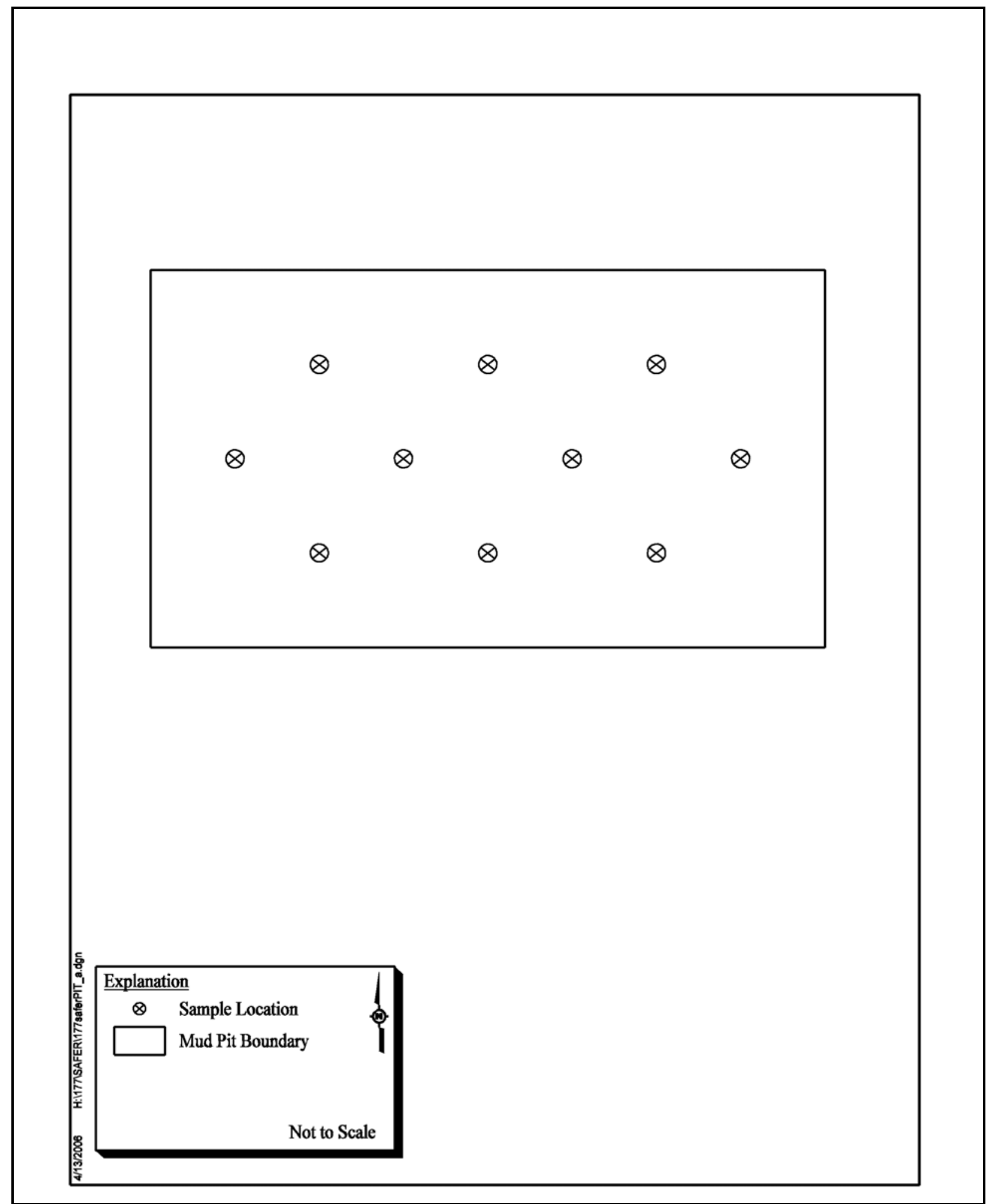

Figure B.8-1

Proposed Sample Locations at Mud Pits 


\section{B.8.2 Cellar Sampling Design}

The cellars are being investigated based on the potential for chemical and radioactive contamination of surface soil at the cellar base. Judgmental samples will be collected from surface soil at the base of an open cellar, or at the first 12 in. of soil directly beneath the cover material for a backfilled cellar based on biasing factors.

During the DQO process it was agreed that a minimum of four samples, two surface and two subsurface, would be sufficient to determine whether contamination exists. The subsurface samples will be collected during Decision I sampling in order to avoid complications with accessing cellar samples at a later time, but may also provide potential Decision II information on vertical migration of contaminants, if any. The locations of the surface samples will be restricted to within the boundaries of the cellar casing because contamination is not expected to have migrated laterally outside of this boundary. The presence and orientation (i.e., direction and angle of installation) of drill stemming left within the cellar cavity may laterally and vertically restrict access to surface and subsurface sample locations. The common post-test drilling situation was to drill at an angle in order to access the zone of rock affected by the test associated with post-test drilling (LLNL, 1984). Based on this process, it is possible to determine the direction at which the drill stemming trends below the ground surface. Sample locations may therefore vary and will be dependent on the following criteria:

- For open cellars, which are confirmed to have drill stemming left in place, surface samples locations, if accessible, will be selected based on biasing factors (defined in Section B.4.2.1.1). In the expected absence of obvious biasing factors, planned sample locations will be either (a) equally distributed on each side of the drill stemming if the entire cellar area is accessible (Figure B.8-2, item [a]), or (b) equally distributed on the side of the cellar that will be accessible for the appropriate sample collection method (Figure B.8-2, item [b]).

- For backfilled cellars, biasing factors are not expected to be apparent. Locations will therefore be selected based on the proposed method for open cellars that lack biasing factors. It will be assumed that drill stemming has been left in place for backfilled cellars in order to avoid contact with the stemming during excavation and sample collection. Access restrictions related to the presence of drill stemming will also be considered for selecting sample locations in backfilled cellars.

Samples will be obtained through either excavation, use of a drill rig, or other appropriate method. Open cellars may be sampled by personnel from the Borehole Management Program for efficiency, 
(a)

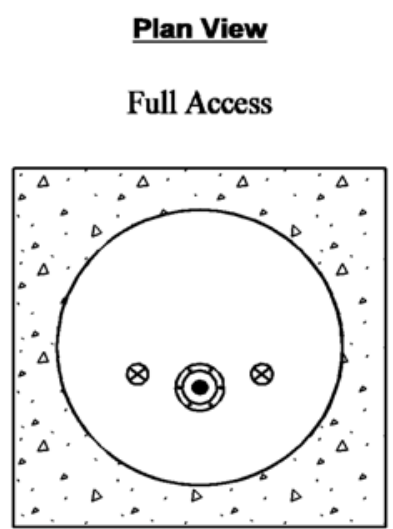

(b)

\section{Plan View}

Potentially Inaccessible

Area

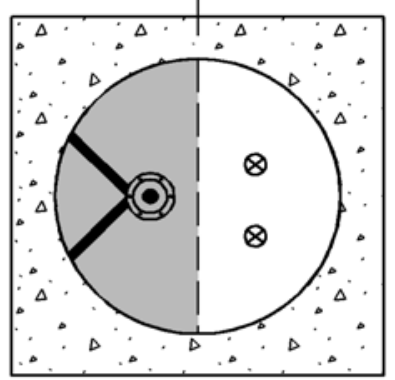

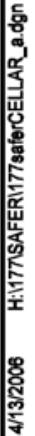
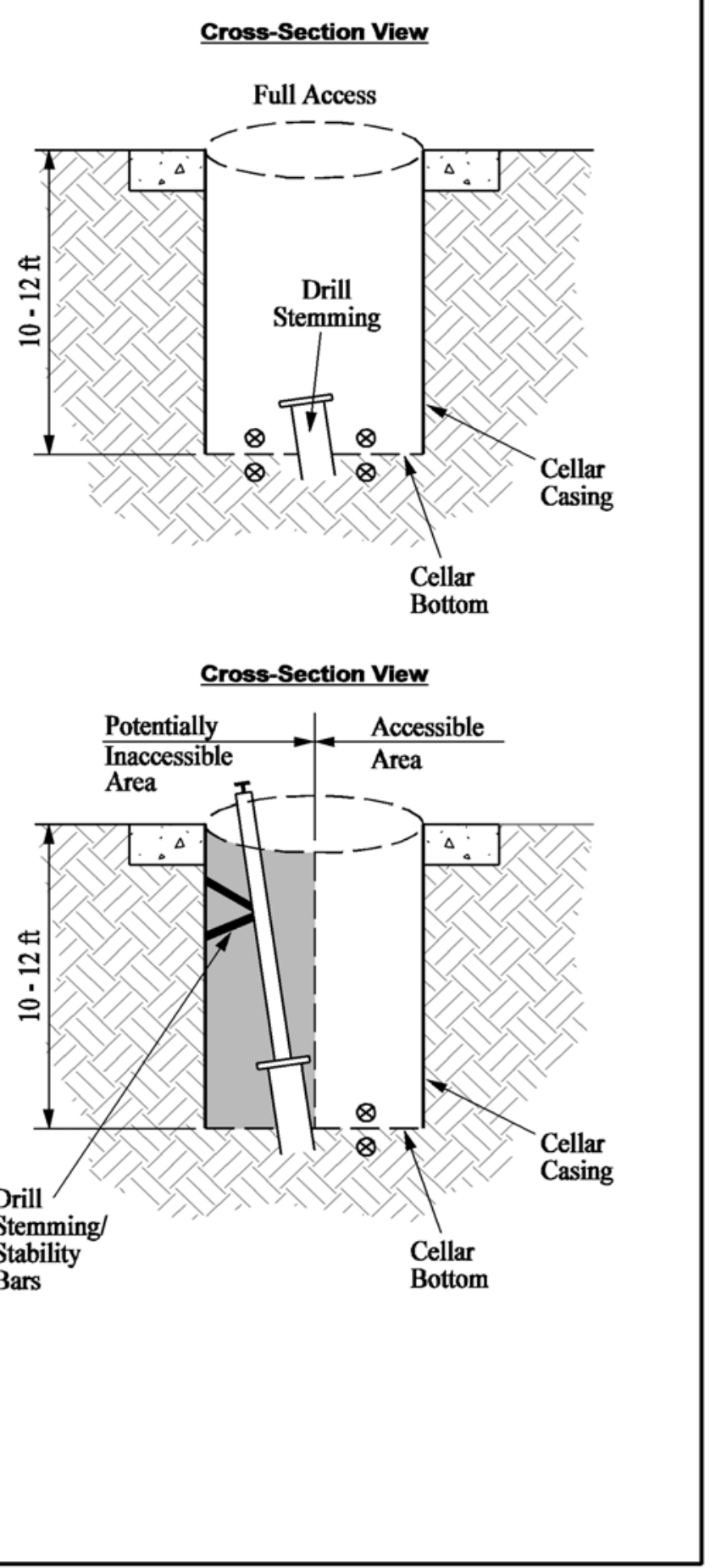

Figure B.8-2

Proposed Sample Locations at Cellars 
because this program has the necessary documentation to enter the cellars. For backfilled cellars, the cover material/surface soil interface is expected to be encountered near a depth of 10 to $12 \mathrm{ft}$ bgs (see Figure B.8-2) based on the assumption that this is the typical depth to the base of a cellar as determined from visual observations at the open cellars of CAU 177. However, this transition horizon between cover material and the underlying surface soil may not be distinguishable. The following lists a procedure similar to the mud pits for obtaining samples from the potentially impacted subsurface soil:

- Soil will be monitored for lithology changes during excavation to determine the cover material/surface soil interface.

- If the interface is recognizable, then a sample will be collected from the first 12 in. of soil directly below the interface.

- If the interface is not recognizable, then a sample will be collected at the depth where the potentially impacted surface soil is expected to be located (i.e., 10 to $12 \mathrm{ft}$ bgs) based on the observations from open cellars.

- If the interface has not been identified and a layer of caliche, or a cement bottom is encountered, then a sample will be collected directly above that layer.

The SS has the discretion to modify the sample locations or order additional biased samples to be collected, but only if the new locations meet the decision needs and criteria stipulated in this DQO. The SS will use professional judgment to determine whether biasing factors (e.g., stains, elevated screening levels) are found during Decision I sampling that might indicate the need to take subsurface Decision II samples. Decision II step-out samples will only be collected in the vertical direction because the lateral migration is restricted to the inside of the cellar casing. If a concrete bottom is encountered, then Decision II step-out samples in the vertical direction may not be collected. The SS will determine whether Decision II sampling is appropriate. 


\section{B.9.0 References}

ASTM, see American Society for Testing and Materials.

American Society for Testing and Materials. 1995. Standard Guide for Risk-Based Corrective Action Applied at Petroleum Release Sites/American Society for Testing and Materials, ASTM E1739-95 (Reapproved 2002). Philadelphia, PA.

DOE/NV, see U.S. Department of Energy, Nevada Operations Office.

EPA, see U.S. Environmental Protection Agency.

IMANA, see Industrial Minerals Association - North America.

Industrial Minerals Association - North America. 2004. Bentonite. As accessed at www.ima-na.org/about_industrial_minerals/bentonite.asp on 3 February 2006. Calverton, MD.

LLNL, see Lawrence Livermore National Laboratory.

Lawrence Livermore National Laboratory. 1984. Postshot Drilling Handbook, January. Livermore, CA.

NAC, see Nevada Administrative Code.

NNSA/NV, see U.S. Department of Energy, National Nuclear Security Administration Nevada Operations Office.

NNSA/NSO, see U.S. Department of Energy, National Nuclear Security Administration Nevada Site Office

Nevada Administrative Code. 2005. NAC 445A.2272, "Contamination of Soil: Establishment of Action Levels.” Carson City, NV.

Pacific Northwest National Laboratory. 2005. Visual Sample Plan Version 4.0 User’s Guide. September. PNNL-14002. Richland, WA.

PNNL, see Pacific Northwest National Laboratory.

SNJV, see Stoller-Navarro Joint Venture.

Stoller-Navarro Joint Venture. Date Unknown. Whitepaper: Assessment of NTS Mud Pit CASs in CAUs 530, 531, 532, 533, 534, and 535 That Are Potentially Contaminated with Radionuclides. 7 July. Las Vegas, NV. 
Shott, G.J., V. Yucel, M.J. Sully, L.E. Barker, S.E. Rawlinson, and B.A. Moore. 1997. Performance Assessment/Composite Analysis for the Area 3 Radioactive Waste Management Site at the Nevada Test Site, Nye County, Nevada, Rev. 2.0. Las Vegas, NV.

USGS/DOE, see U.S. Geological Survey and U.S. Department of Energy.

U.S. Department of Energy, National Nuclear Security Administration Nevada Operations Office. 2002. Industrial Sites Quality Assurance Project Plan, Nevada Test Site, Nevada, Rev. 3, DOE/NV--372. Las Vegas, NV.

U.S. Department of Energy, National Nuclear Security Administration Nevada Site Office. 2003a. Closure Report for Corrective Action Unit 355: Area 2 Cellars/Mud Pits, Nevada Test Site, Nevada, DOE/NV--934-Rev. 0, November. Las Vegas, NV.

U.S. Department of Energy, National Nuclear Security Administration Nevada Site Office. 2003b. Draft Closure Report for Corrective Action Unit 358: Area 18, 19, 20 Cellars/Mud Pits, Nevada Test Site, Nevada, November. Las Vegas, NV.

U.S. Department of Energy, National Nuclear Security Administration Nevada Site Office. 2004. Mud Pit Risk-Based Closure Strategy Report, Nevada Test Site, Nevada, DOE/NV--991. Las Vegas, NV.

U.S. Department of Energy, National Nuclear Security Administration Nevada Site Office. 2005. Streamlined Approach for Environmental Restoration Plan for Corrective Action Units 530, 531, 532, 533, 534, and 535, Nevada Test Site Mud Pits, Nevada Test Site, Nevada, DOE/NV--1057. July. Las Vegas, NV.

U.S. Department of Energy, National Nuclear Security Administration Nevada Site Office. 2006. Industrial Sites Project Establishment of Final Action Levels. February. Las Vegas, NV.

U.S. Department of Energy, Nevada Operations Office. 1992. Remedial Investigation and Feasibility Study for the Plutonium Contaminated Soils at Nevada Test Site, Nellis Air Force Range and Tonopah Test Range, April. Las Vegas, NV.

U.S. Department of Energy, Nevada Operations Office. 1998a. Evaluation of Potential Hydrocarbon Transport at the UC-4 Emplacement Hole, Central Nevada Test Area, DOE/NV-11508-43. Prepared by B.F. Lyles, G.Pohll, D.Sloop, C. Papelis. Las Vegas, NV.

U.S. Department of Energy, Nevada Operations Office. 1998b. Nevada Test Site Resource Management Plan, DOE/NV-518. Las Vegas, NV.

U.S. Department of Energy, Nevada Operations Office. 2001. Mud Pit Strategy, Nevada Test Site, Nevada, DOE/NV-684. Las Vegas, NV. 
U.S. Environmental Protection Agency. 2000a. Data Quality Objectives Process for Hazardous Waste Site Investigations. EPA QA/G-4HW. Washington, DC.

U.S. Environmental Protection Agency. 2000b. Guidance for the Data Quality Objective Process, EPA QA/G4. Washington, DC.

U.S. Environmental Protection Agency. 2000c. Multi-Agency Radiation Survey and Site Investigation Manual (MARSSIM). EPA 402-R-97-016, Rev.1. Washington, DC.

U.S. Environmental Protection Agency. 2002a. Guidance on Choosing a Sampling Design for Environmental Data Collection. EPA QA/G-5S. Washington, DC.

U.S. Environmental Protection Agency. 2002b. Guidance for Quality Assurance Project Plans. EPA QA/G-5. Washington, DC.

U.S. Environmental Protection Agency. 2004. ProUCL Version 3.0 User Guide. EPA/600/R04/079. Washington, DC.

U.S. Geological Survey and U.S. Department of Energy. 2005. "USGS/USDOE Cooperative Studies in Nevada Periodic Water Levels -- Nevada Test Site Map.” As accessed at http://nevada.usgs.gov/doe_nv/doe_nv/ntsmap.htm on 2 February 2006.

Winograd, I.J., and W. Thordarson. 1975. Hydrology and Hydrochemical Framework, South-Central Great Basin, Nevada-California, with Special Reference to the Nevada Test Site, USGS Professional Paper 712-C. Denver, CO. 
Appendix C

Probabilistic Sampling Plan 


\section{C.1.0 Probabilistic Sampling Plan}

\section{C.1.1 Purpose}

A probabilistic (random) sampling design was specified by the DQO meeting participants for all mud pits of CAU 177 (CASs 08-23-01, 09-09-41, 09-09-45, 09-23-05, 09-23-08, 10-23-02, 10-23-03, and 19-23-01). This approach will allow for mud pits to be characterized by evaluating contamination as a whole rather than individual locations within the mud pit. A proposed number of 10 sample locations for each mud pit in CAU 177 was agreed upon by decision makers during the February 21, 2006, DQO meeting. This sample size was accepted based on the investigation of the CAU 530-535 mud pits.

This appendix provides the methodology used to design the probabilistic sampling plan that will be used to characterize mud pits, the specific number and locations of samples to be collected, and the statistical tests to be applied to the data upon completion of the investigation.

\section{C.1.2 Methodology}

The objective of the probabilistic sampling design is to determine, with a specified degree of confidence, whether the true average contaminant concentrations at the site in question poses an unacceptable risk to human health and the environment (EPA, 2000). The averages from sample analytical results for each constituent are an estimation of the true average contaminant concentrations. Final action levels represent the lowest site contaminant concentrations deemed to pose an unacceptable risk to human health and the environment. Average concentrations less than the FALs are considered not to pose an unacceptable risk to human health.

Because the average contaminant concentrations from samples is only an estimate of the true (unknown) average contaminant concentrations, it is uncertain how well the sample averages represent the true averages. If a sample average was directly compared to the FAL, a significant difference between the true average and the sample average could lead to making decision errors. To reduce the probability of making a false negative decision error, a conservative estimate of the true average is used to compare to the FAL. This conservative estimate (overestimation) of the true contaminant concentration averages will be calculated as the 95 percent UCL of the respective 
sample contaminant concentration averages. By definition, there will be a 95 percent probability that the true average concentration is less than the 95 percent UCL of the sample average.

\section{C.1.2.1 Computation of the Upper Confidence Limit}

The computation of appropriate UCLs depends upon the data distribution, the number of samples, the variability of the dataset, and the skewness associated with the dataset. A statistical package will be used to determine the appropriate probability distribution (e.g., normal, lognormal, gamma) and/or a suitable non-parametric distribution-free method and then to compute appropriate UCLs. To ensure that the appropriate UCL computational method is used, the sample data will be tested for goodness-of-fit to all of the parametric and non-parametric UCL computation methods described in the EPA Guidance Document to Calculate the Upper Confidence Limits for Exposure Point Concentrations at Hazardous Waste Sites (OSWER 9285.670) (EPA, 2002).

A UCL will be calculated for each COPC that is detected in any sample at a concentration greater than the PAL. Computation of an appropriate UCL requires that a minimum number of samples be collected from random locations at each site and a basic assumption that:

- The data originate from a symmetric, but not necessarily normally distributed, population.

- The estimation of the variability is reasonable and representative of the population being sampled.

- The population values are not temporally or spatially correlated.

\section{C.1.2.2 Sample Size}

A minimum number of samples is required to compute a UCL. Because the minimum number of samples needed to perform the UCL comparison tests cannot be determined until after investigation results are obtained, a number of 10 samples per mud pit will be collected during the investigation, as agreed upon by decision makers. Selection of this number is based upon the investigation of mud pits from CAU 530-535, in which 10 samples per mud pit was a sufficient minimum number of samples required to compute a UCL.

Following the investigation of CAU 177, the true minimum sample size will be calculated from the actual investigation results for each of the significant COPCs to verify that sufficient samples were 
collected. This will be done using the Visual Sampling Plan (VSP) software which was developed by Pacific Northwest National Laboratory (PNNL) for the DOE and the EPA to determine the minimum number of samples needed to characterize a site based on the type of test to be performed, the distribution of the data, the variability of the data, and the false positive and false negative error rates agreed to during the planning stages (PNNL, 2005).

As agreed to by the DQO meeting participants on February 21, 2006, the input parameters to be used in calculating the true minimum sample size are:

- A confidence level that a false negative error will not occur will be set at 95 percent.

- A confidence level that a false positive error will not occur will be set at 80 percent.

- A gray region width of 50 percent of each COPC action level.

\section{C.1.2.3 Sample Location Selection}

The location of the 10 initial samples will be determined in VSP using a triangular grid pattern that is based on a randomly selected start location, and the mud pit perimeters that were obtained using GPS collection methods. Figures C.1-1 through C.1-10 show the VSP generated locations and coordinates of each sample within the spatial boundaries of each mud pit. At CAS 19-23-01 the current field conditions required alternate mud pit perimeters to be generated. The mud pit boundaries are not well defined at this CAS, so three layouts (labeled A, B, and C) were generated. Layout A (Figure C.1-8) represents a perimeter around a large soil mound, which is believed to best represent the location of the backfilled mud pit. Layout B (Figure C.1-9) represents a perimeter that includes the soil mound and an area of mud at its south end. Layout $\mathrm{C}$ represents a perimeter that encloses the dirt mound, mud, and surrounding disturbed area, which is bounded on the east, west, and south sides by berms. The layout of sample locations selected during the investigation of CAS 19-23-01 will be dependent on site specific field conditions and will be documented in the FADL and closure report. In the event that unforeseen site specific conditions at other CASs will require the VSP software to regenerate sample locations, the new layout will also be documented in the FADL and closure report, but a ROTC will not be generated for this SAFER Plan. If it is determined that additional samples need to be collected based on the determination of minimum sample size using actual sample results, additional sample locations will be determined using the same methodology (for five or more samples) or by randomly selecting each sample location (for less than five samples). 


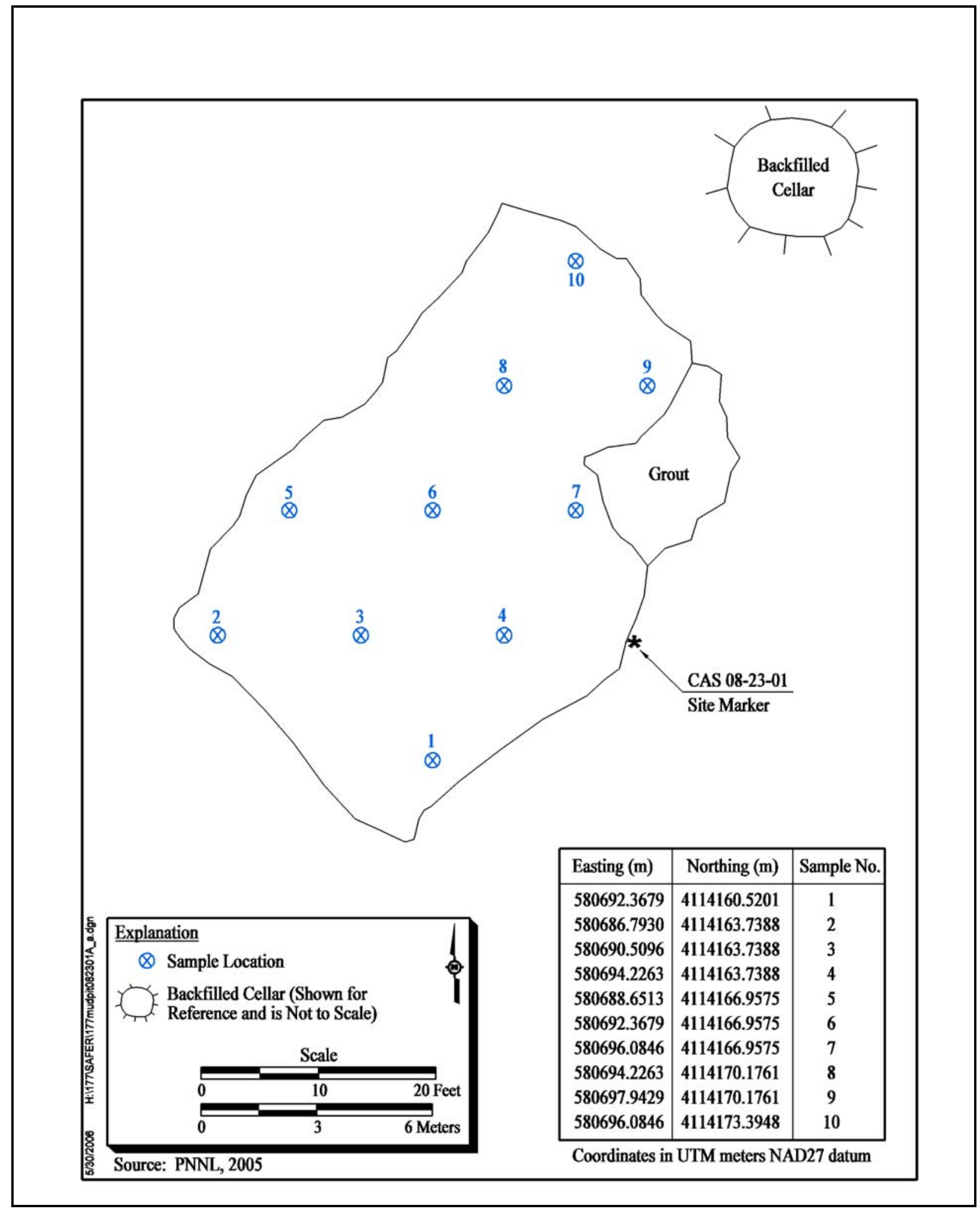

Figure C.1-1

Corrective Action Site 08-23-01, Sample Locations and Coordinates 


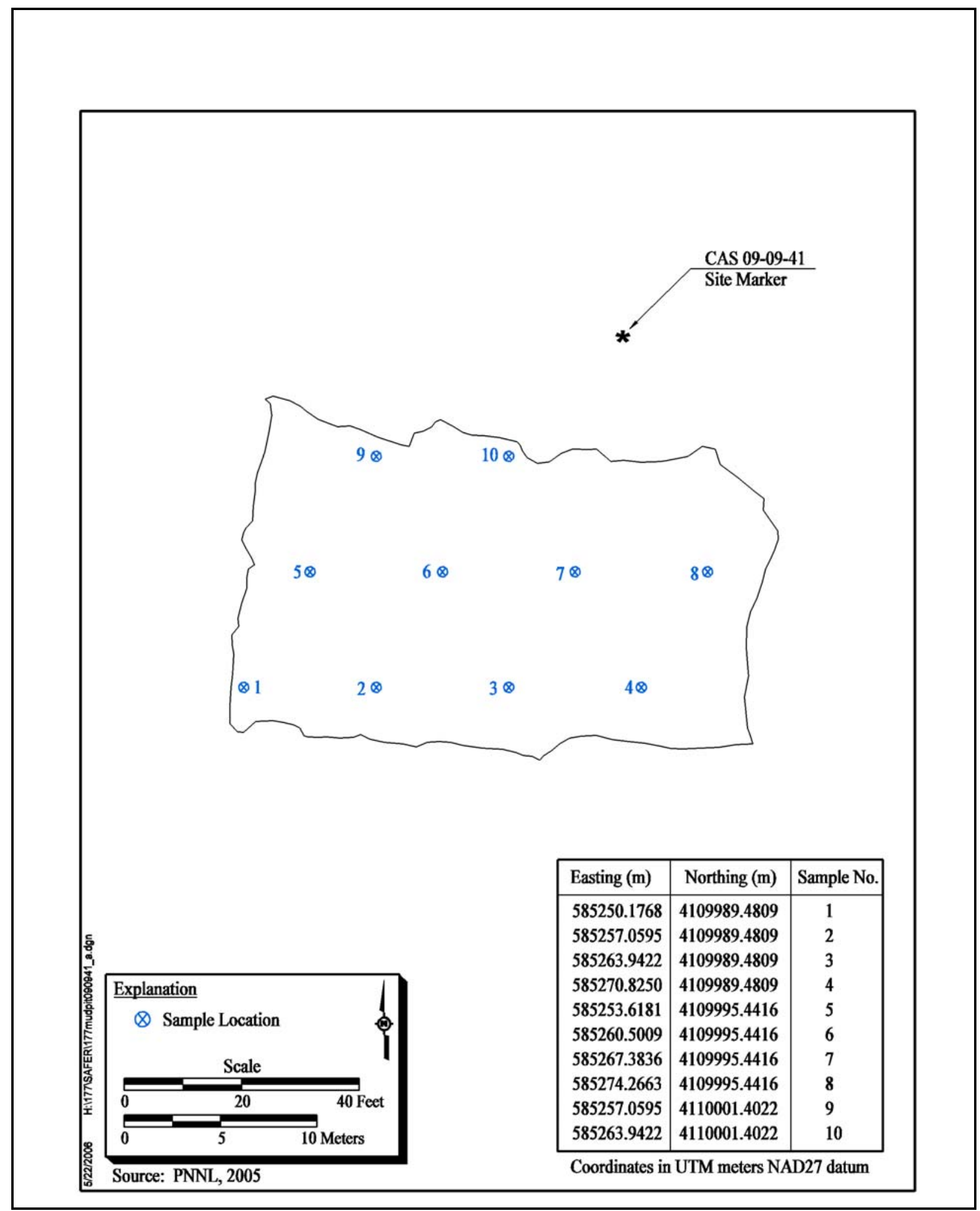

Figure C.1-2

Corrective Action Site 09-09-41, Sample Locations and Coordinates 


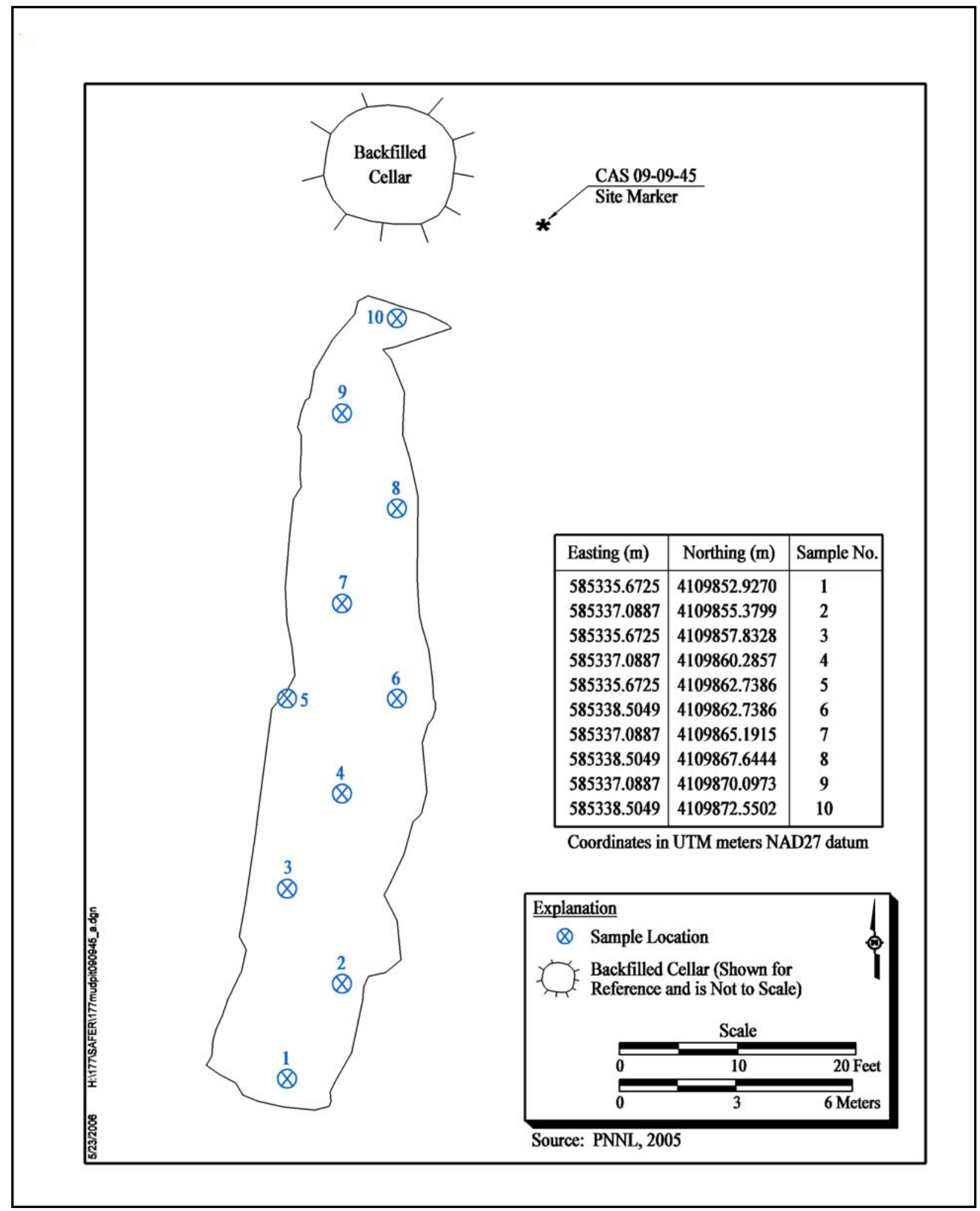

Figure C.1-3

Corrective Action Site 09-09-45, Sample Locations and Coordinates 


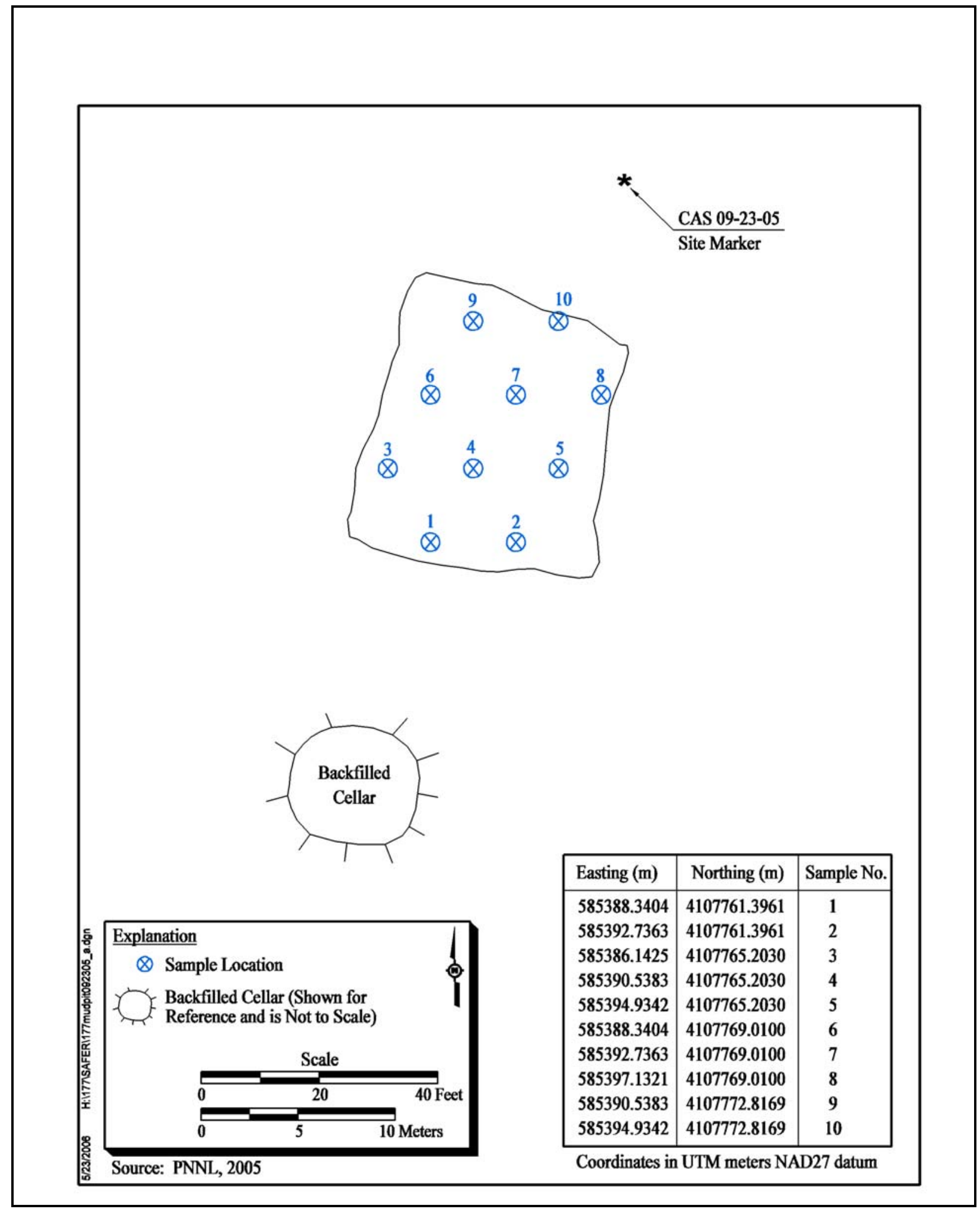

Figure C.1-4

Corrective Action Site 09-23-05, Sample Locations and Coordinates 


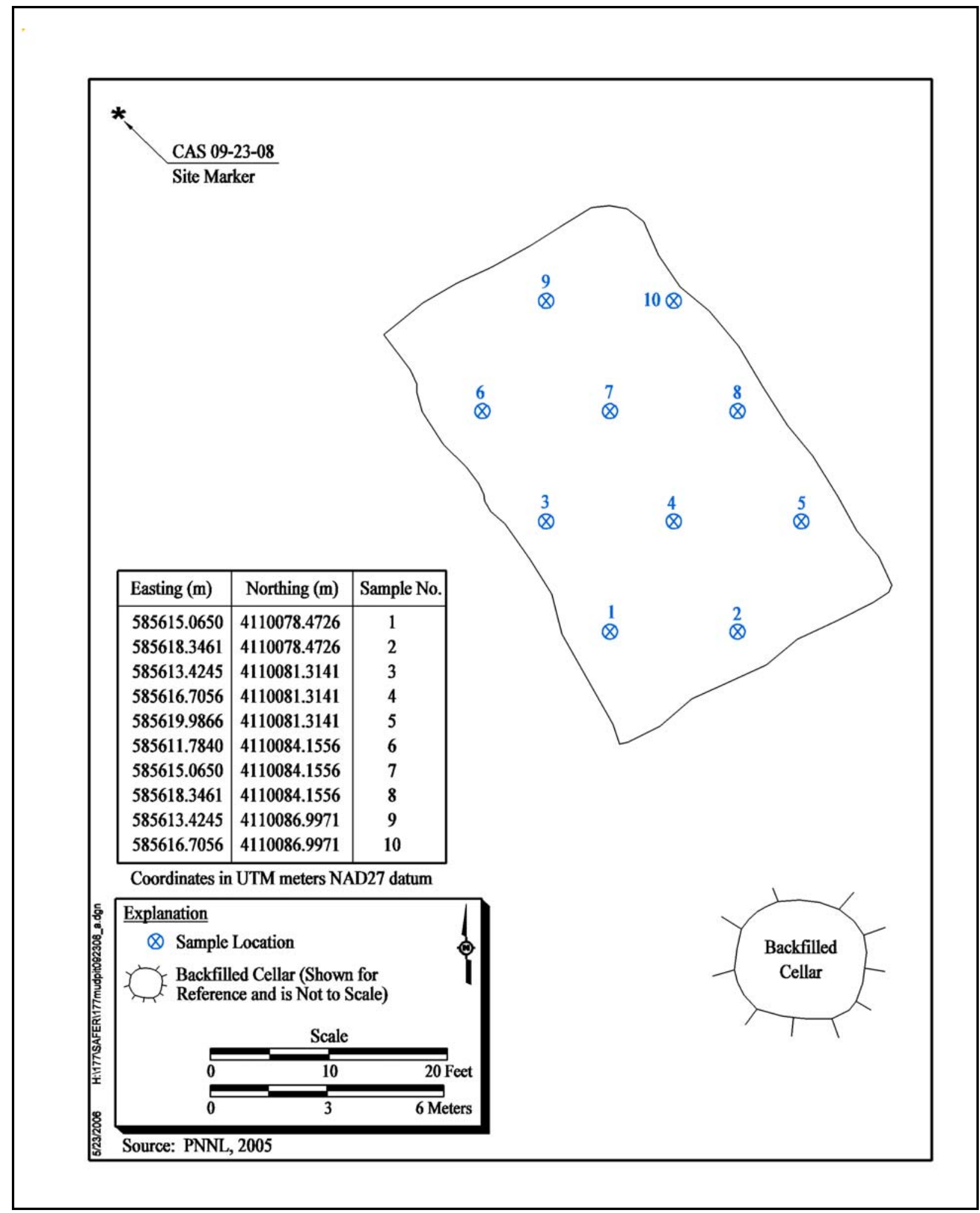

Figure C.1-5

Corrective Action Site 09-23-08, Sample Locations and Coordinates 


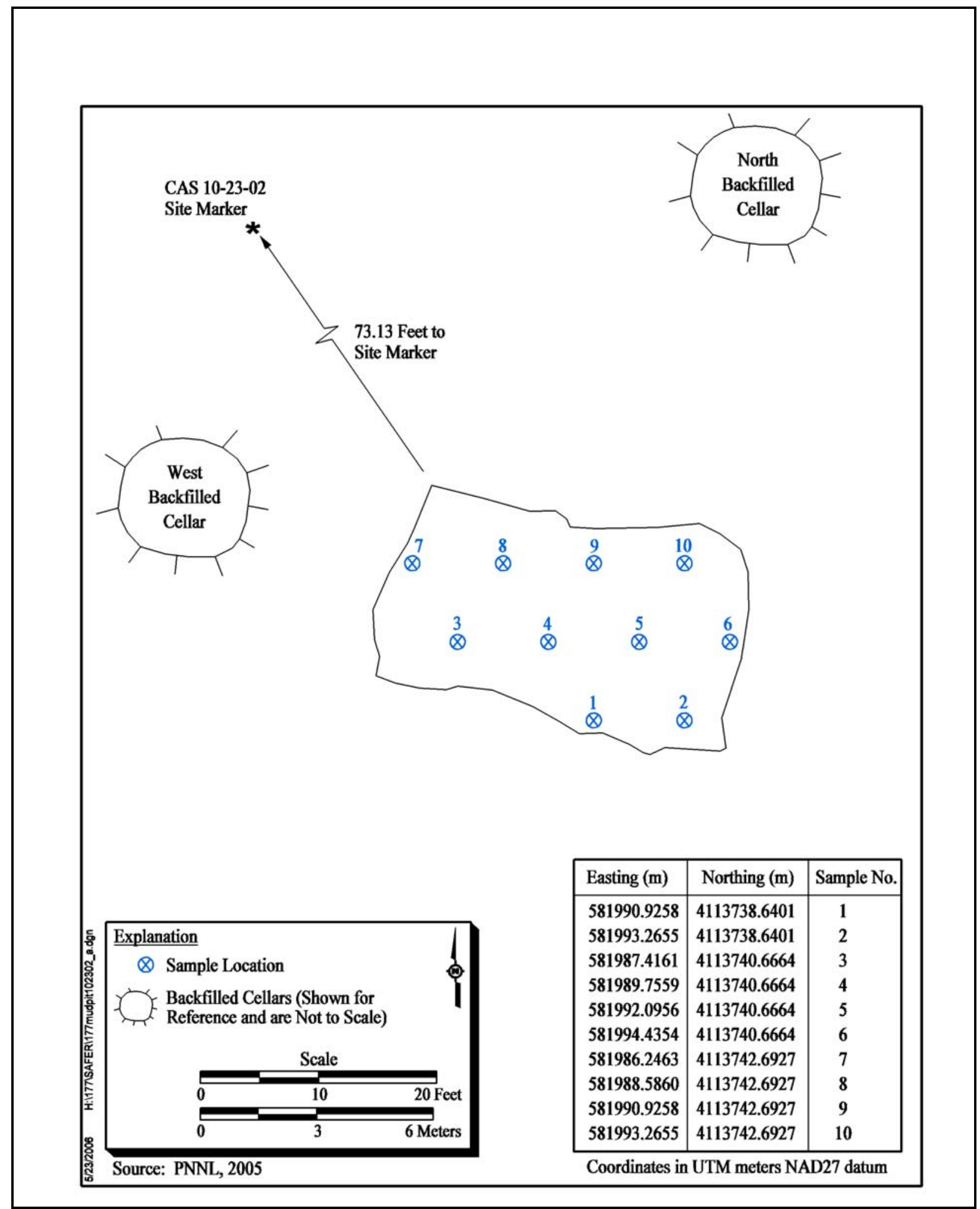

Figure C.1-6

Corrective Action Site 10-23-02, Sample Locations and Coordinates 

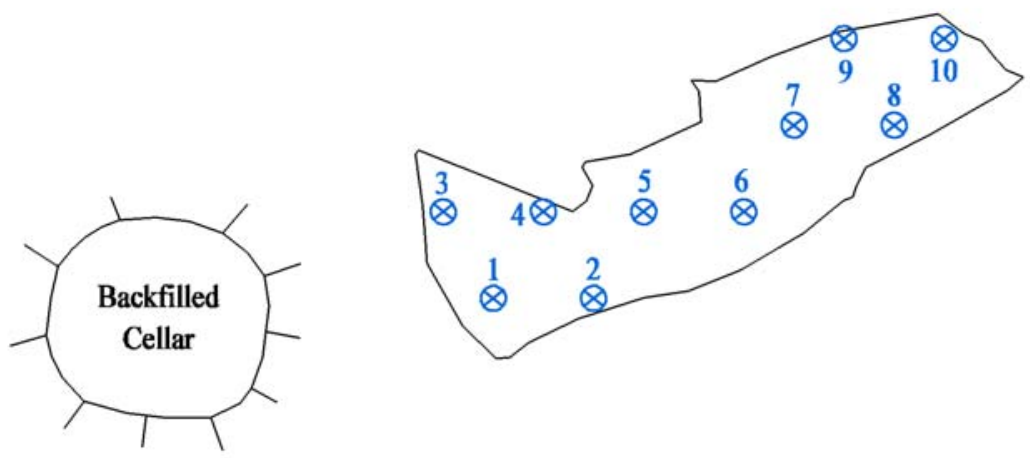

CAS 10-23-03

Site Marker

$\otimes$ Sample Location

Backfilled Cellar (Shown for Reference and is Not to Scale)

Scale

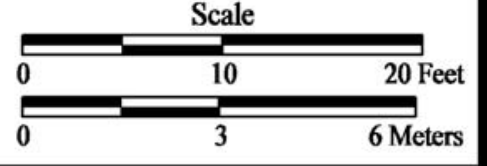

\begin{tabular}{|l|c|c|}
\hline Easting $(\mathrm{m})$ & Northing $(\mathrm{m})$ & Sample No. \\
\hline 581715.8448 & 4113754.2216 & 1 \\
581717.3735 & 4113754.2216 & 2 \\
581715.0805 & 4113755.5455 & 3 \\
581716.6092 & 4113755.5455 & 4 \\
581718.1379 & 4113755.5455 & 5 \\
581719.6666 & 4113755.5455 & 6 \\
581720.4309 & 4113756.8694 & 7 \\
581721.9596 & 4113756.8694 & 8 \\
581721.1953 & 4113758.1933 & 9 \\
581722.7240 & 4113758.1933 & 10 \\
\hline
\end{tabular}

Source: PNNL, 2005

Coordinates in UTM meters NAD27 datum

Figure C.1-7

Corrective Action Site 10-23-03, Sample Locations and Coordinates 


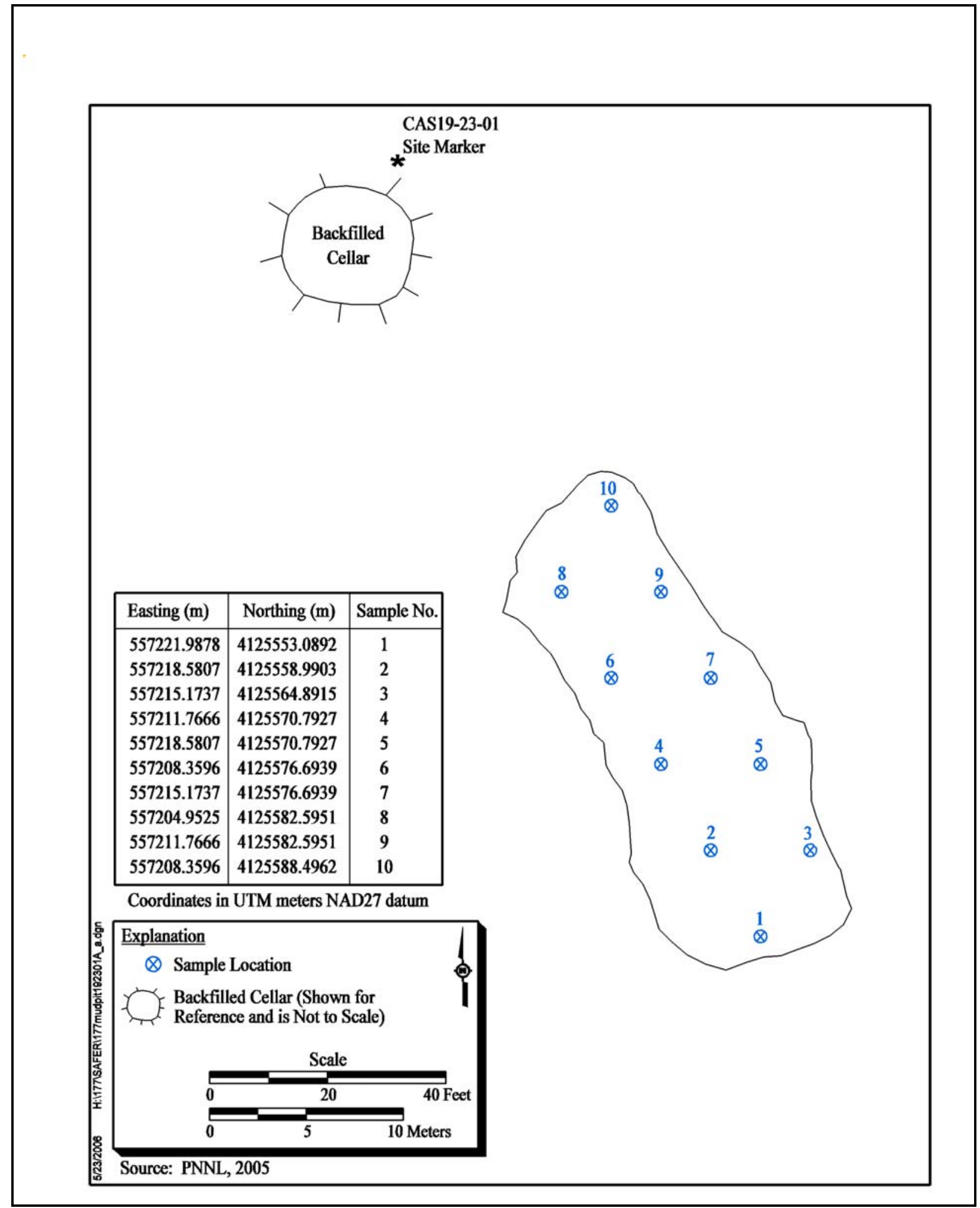

Figure C.1-8

Corrective Action Site 19-23-01, Sample Locations and Coordinates, Layout A 


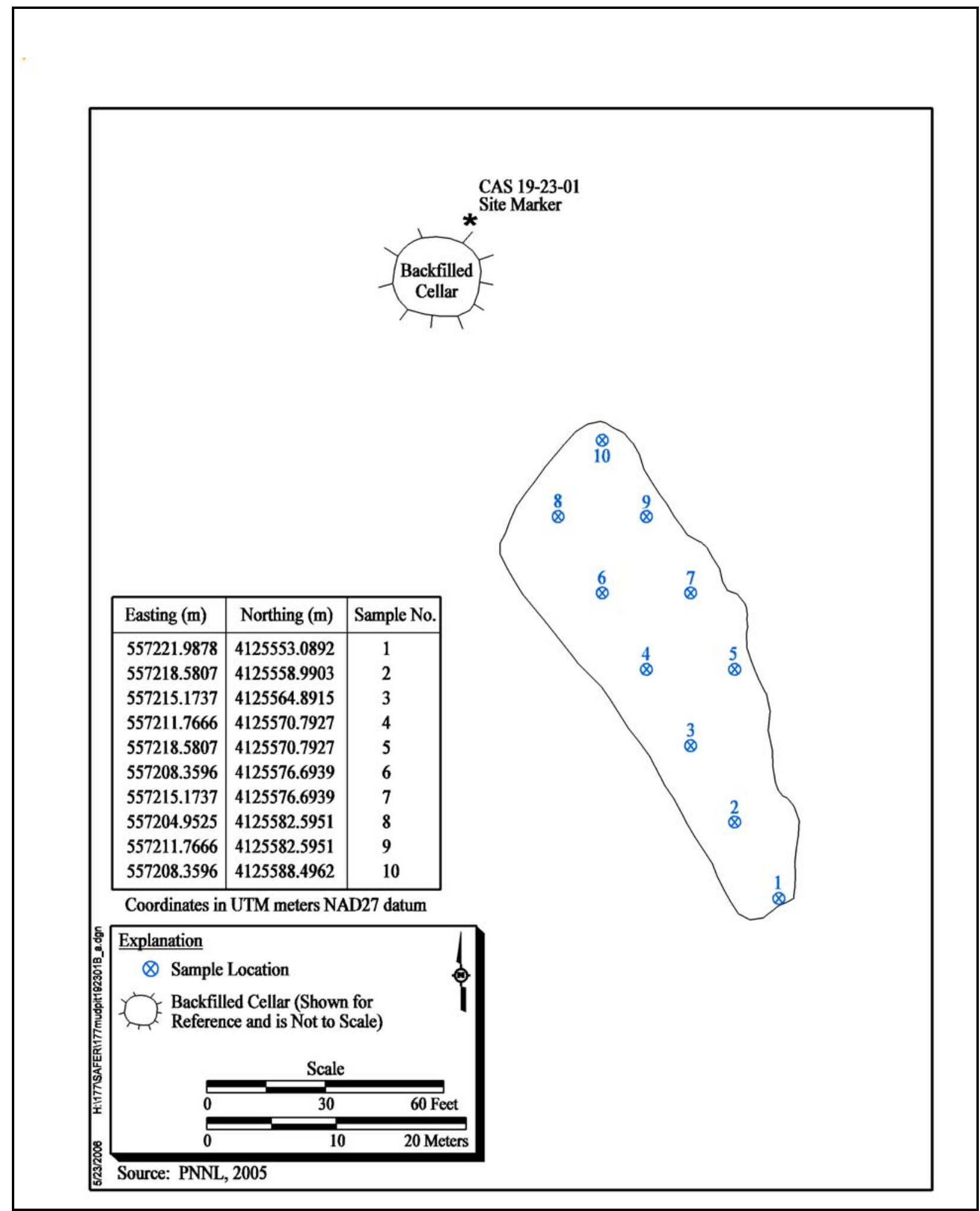

Figure C.1-9

Corrective Action Site 19-23-01, Sample Locations and Coordinates, Layout B 


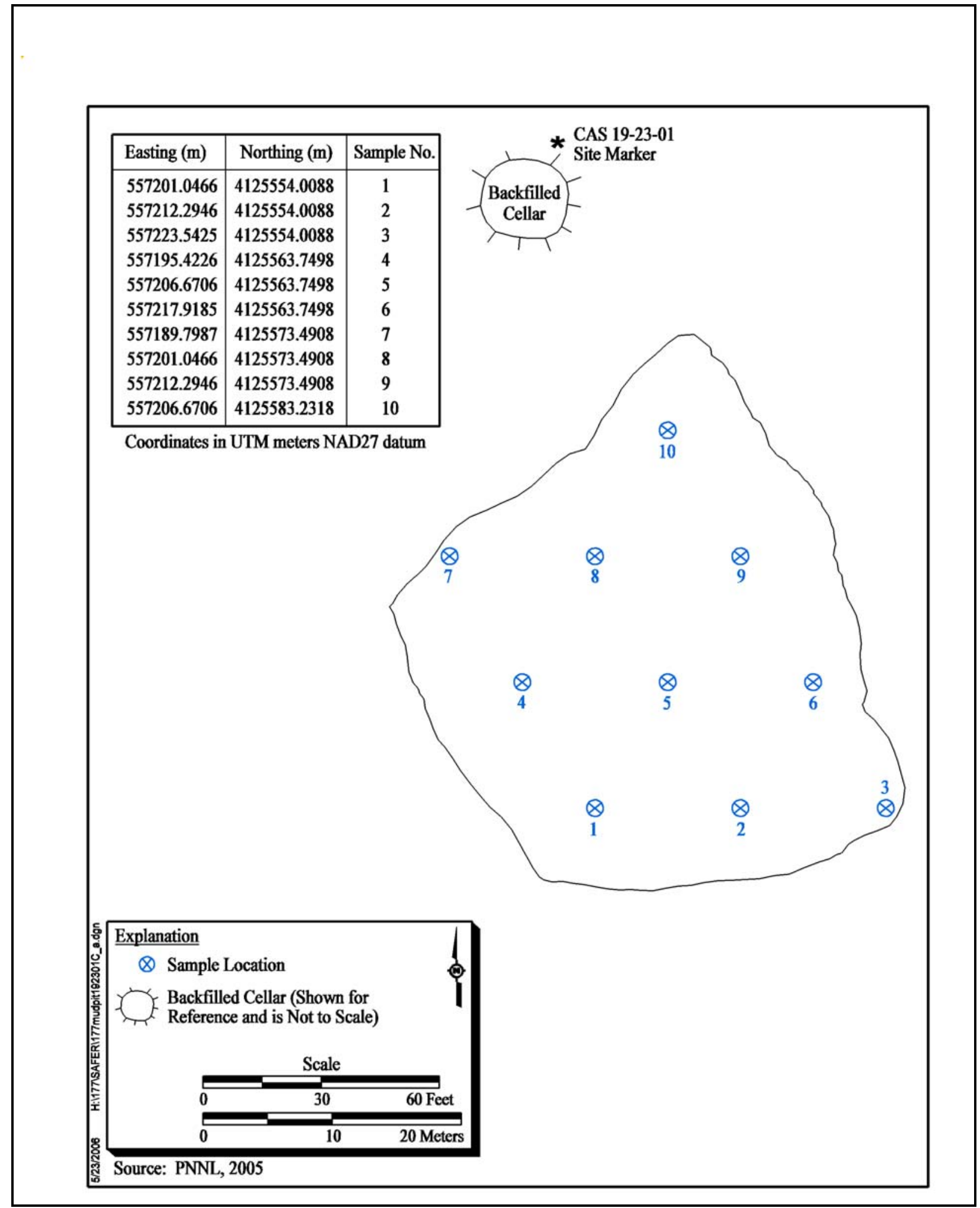

Figure C.1-10

Corrective Action Site 19-23-01, Sample Locations and Coordinates, Layout C 


\section{C.2.0 References}

EPA, see U.S. Environmental Protection Agency.

PNNL, see Pacific Northwest National Laboratory.

Pacific Northwest National Laboratory. 2005. Visual Sampling Plan Version 4.0, User's Guide PNNL-14002. Richland, WA.

U.S. Environmental Protection Agency. 2000. Data Quality Objectives Process for Hazardous Waste Site Investigations. EPA QA/G-4HW. Washington, DC.

U.S. Environmental Protection Agency. 2002. Calculating Upper Confidence Limits for Exposure Point Concentrations at Hazardous Waste Sites. December. Washington, DC: Office of Emergency and Remedial Response. 


\title{
Appendix D
}

\section{Nevada Division of Environmental Protection Comments}

\author{
(1 Page)
}




\section{NEVADA ENVIRONMENTAL RESTORATION PROJECT DOCUMENT REVIEW SHEET}

\begin{tabular}{|l|l|}
\hline $\begin{array}{l}\text { 1. Document Title/Number: } \\
\quad \begin{array}{l}\text { Draft Draft Streamlined Approach for Environmental Restoration } \\
\text { Plan for Corrective Action Unit 177: Mud Pits and Cellars, Nevada } \\
\text { Test Site, Nevada }\end{array}\end{array}$ & 2. Document Date: 05/17/2006 \\
\hline 3. Revision Number: 0 & 4. Originator/Organization: Stoller-Navarro \\
\hline 5. Responsible NNSA/NV ERP Project Manager: Sabine T. Curtis & 6. Date Comments Due: 05/17/2006 \\
\hline 7. Review Criteria: Full & 9. Reviewer's Signature: \\
\hline 8. Reviewer/Organization/Phone No: Tim Murphy and Don Elle, NDEP, 486-2850 &
\end{tabular}

\begin{tabular}{|l|l|l|l|}
\hline $\begin{array}{l}\text { 10. Comment } \\
\text { Number/Location }\end{array}$ & 11. Type & 12. Comment & 13. Comment Response \\
\hline 1.) General & Mandatory & $\begin{array}{l}\text { Sample locations to be determined by radiological surveys } \\
\text { and Global Positioning System surveys must be documented } \\
\text { and provided in the final SAFER Plan. }\end{array}$ & $\begin{array}{l}\text { Appendix C discusses the Visual Sample Plan (VSP) } \\
\text { methodology for generating probabilistic sample } \\
\text { locations at CAU 177 mud pits. Added to this } \\
\text { appendix are Figures C.1-1 through C.1-10, which } \\
\text { show the VSP generated locations and coordinates } \\
\text { of each sample location within the spatial boundaries } \\
\text { of each mud pit. Sections C.1.1, C.1.2.2, and C.1.2.3 } \\
\text { were revised to incorporate information related to the } \\
\text { documentation of sample locations. Also, only GPS } \\
\text { surveys were needed to be conducted in order to } \\
\text { determine sample locations using VSP. The } \\
\text { reference to radiological surveys in the Draft SAFER } \\
\text { was incorrect. }\end{array}$ \\
\hline
\end{tabular}




\title{
Library Distribution List
}

\author{
$\underline{\text { Copies }}$ \\ U.S. Department of Energy \\ 1 (Uncontrolled) \\ National Nuclear Security Administration \\ Nevada Site Office \\ Technical Library \\ P.O. Box 98518, M/S 505 \\ Las Vegas, NV 89193-8518 \\ U.S. Department of Energy \\ Office of Scientific and Technical Information \\ 1 (Uncontrolled, electronic copy) \\ P.O. Box 62 \\ Oak Ridge, TN 37831-0062 \\ Southern Nevada Public Reading Facility \\ 1 (Controlled) \\ c/o Nuclear Testing Archive \\ 1 (Uncontrolled) \\ P.O. Box 98521, M/S 400 \\ Las Vegas, NV 89193-8521 \\ Manager, Northern Nevada FFACO \\ 1 (Uncontrolled) \\ Public Reading Facility \\ c/o Nevada State Library \& Archives \\ Carson City, NV 89701-4285
}

